\title{
High Temperature Gas- Cooled Reactor Projected Markets and Preliminary Economics
}

The INL is a

U.S. Department of Energy National Laboratory

operated by

Battelle Energy Alliance

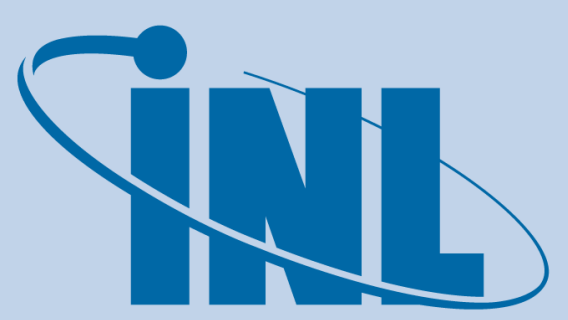

Idaho National Laboratory

August 2011

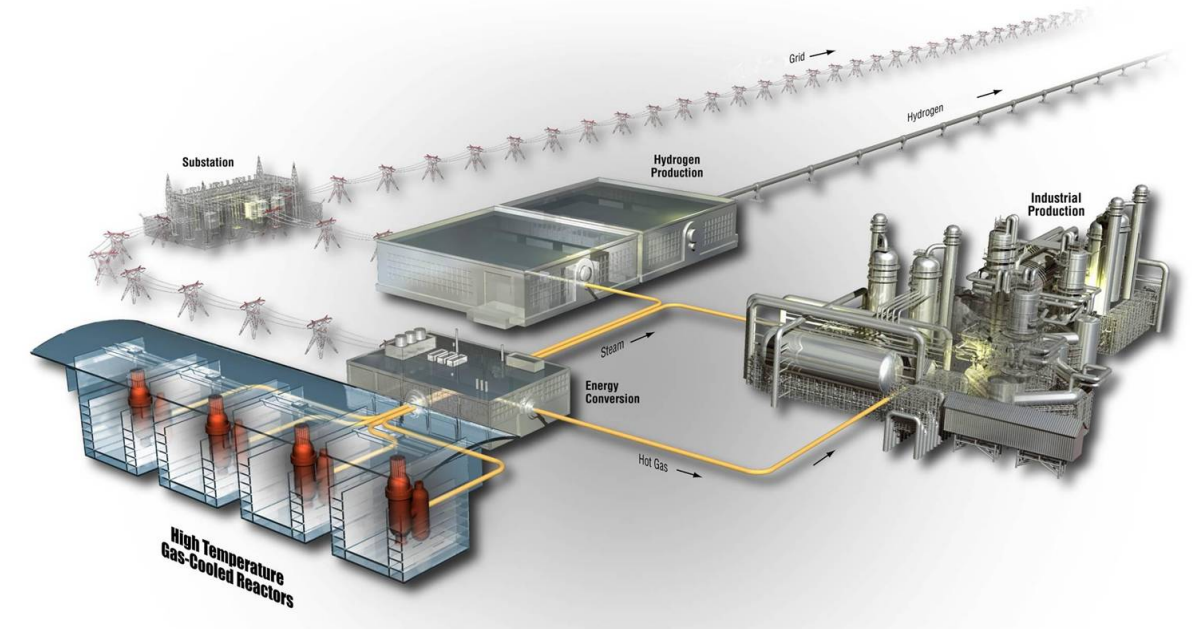




\section{DISCLAIMER}

This information was prepared as an account of work sponsored by an agency of the U.S. Government. Neither the U.S. Government nor any agency thereof, nor any of their employees, makes any warranty, expressed or implied, or assumes any legal liability or responsibility for the accuracy, completeness, or usefulness, of any information, apparatus, product, or process disclosed, or represents that its use would not infringe privately owned rights. References herein to any specific commercial product, process, or service by trade name, trade mark, manufacturer, or otherwise, does not necessarily constitute or imply its endorsement, recommendation, or favoring by the U.S. Government or any agency thereof. The views and opinions of authors expressed herein do not necessarily state or reflect those of the U.S. Government or any agency thereof. 


\title{
High Temperature Gas-Cooled Reactor Projected Markets and Preliminary Economics
}

\author{
August 2011 \\ Revision 1
}

\begin{abstract}
Idaho National Laboratory
Next Generation Nuclear Plant Project

Idaho Falls, Idaho 83415
\end{abstract}

http://www.inl.gov

Prepared for the

U.S. Department of Energy

Office of Nuclear Energy

Under DOE Idaho Operations Office

Contract DE-AC07-05ID14517 

Next Generation Nuclear Plant Project

\section{High Temperature Gas-Cooled Reactor Projected Markets and Preliminary Economics}

INL/EXT-10-19037

Revision 1

August 2011

Approved by:
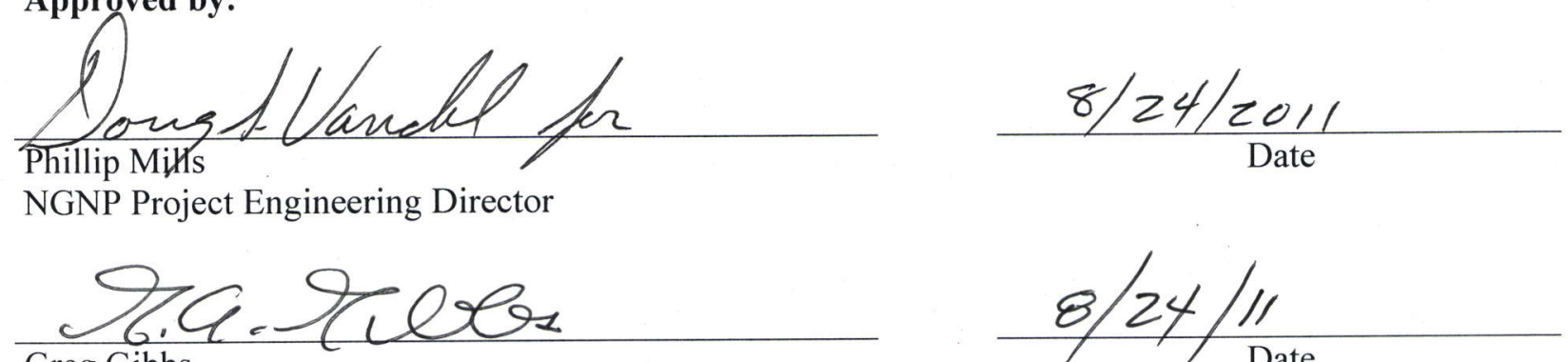

Greg Gibbs

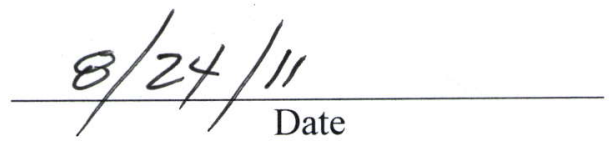

NGNP Project Director 



\begin{abstract}
This paper summarizes the: potential market for process heat produced by a high temperature gas-cooled reactor (HTGR), environmental benefits of reduced $\mathrm{CO}_{2}$ emissions from the substitution of the emissions-free HTGR for traditional carbon-based energy supplies, benefits of a long term stable energy price free from the wide swings in energy pricing experienced over the last decade, and the typical economics of projects using these applications. It provides examples of HTGR technology applications to industrial processes for co-generation supply of process heat and electricity, the conversion of coal to transportation fuels and chemical process feedstock, and the production of ammonia as a feedstock for the production of ammonia derivatives, including fertilizer. It also demonstrates how uncertainties in capital costs and financial factors affect the economics of HTGR technology in the application of HTGR and high temperature steam electrolysis processes to produce hydrogen.
\end{abstract}




\section{SUMMARY}

The NGNP Project is developing and enabling the initial commercial deployment of the high temperature gas-cooled reactor (HTGR) technology to supply high temperature process heat to industrial processes as a substitute for the burning of premium fossil fuels, such as natural gas. Commercial applications for HTGR technology evaluated by the NGNP Project include electricity generation, supplying steam and high-temperature gas to a wide range of industrial processes, and the production of industrial gases (hydrogen and oxygen) for use in petrochemical, refining, coal-to-liquid fuels, chemical, and fertilizer plants. As a non- $\mathrm{CO}_{2}$ emitting substitute for the burning of carbon fuels, the HTGR can offset significant quantities of industry-generated $\mathrm{CO}_{2}$ emissions. The use of the HTGR technology as an energy substitute for natural gas in many of these applications and for conversion of coal to synthetic fuels and chemical process feedstock improves the security of the U.S. energy supply by reducing reliance on imports, reducing the energy price volatility that has been experienced over the last few decades (e.g., wide swings in the prices of oil, natural gas, and coal), and extending the life of nonrenewable energy resources for use within more productive and efficient applications where no current alternatives are available.

Market studies have identified a large market potential for the HTGR technology. The highest priorities include the displacement of natural gas and other hydrocarbons for process steam/electricity cogeneration applications (e.g., petrochemical production, petroleum refining, and ammonia production), enhanced oil recovery and upgrading (e.g., from oil sands and oil shale), synthetic transportation fuel and feedstock production from coal and biomass, hydrogen production supporting all the above potential applications, and metals production. Technical evaluations have been completed to show the viability of integrating the HTGR technology with conventional processes in these market sectors. Trade studies have shown the potential for integrating the HTGR technology into conventional processes for supplying steam, electricity, and high-temperature gas in co-generation applications; for production of hydrogen and for the use of it in the production of gasoline in methanol-to-gasoline processes; and production of diesel fuel in coal and biomass-to-liquid fuel conversion processes in the synthesis of ammonia.

The modular characteristics (e.g., module ratings from 200 to $625 \mathrm{MWt}$ ) and low water usage of the HTGR technology facilitate its application for electricity generation in areas with limited electric power transmission capacity, low cooling water availability, or other factors that would otherwise be unable to take advantage of nuclear energy. The thermal efficiency of the HTGR is also higher than that attainable with light water reactor technology (e.g., 40 to $45 \%$ net efficiency for an HTGR versus $\sim 30 \%$ for an LWR). Accordingly, electricity generation is also potentially a very significant market for the HTGR technology.

These evaluations of the potential market and preliminary economics provide a foundation for making decisions on technical requirements for the HTGR module designs as the NGNP Project moves forward. The overall functional and performance requirements derived from these studies provide the basis for detailed design specifications to be developed by the nuclear systems suppliers in cooperation with the future HTGR plant owners. In contrast to LWRs for electric power generation, it is anticipated that as the high temperature process heat and related markets mature and the actual owners step forward to invest, a spectrum of designs will emerge that best fit each market. A primary objective of the NGNP Project is to envelop the most important of these functional and performance requirements in its supporting development work and in selecting a representative first-of-a-kind application that provides a demonstration that can be applied to broadest possible future markets. 
Full realization of the NGNP Project estimate in penetrating the targeted markets for the HTGR technology over the time frame of mid-2020 to 2050 would result in:

- Deployment of $\sim 488,400 \mathrm{MWt}$ (megawatts thermal) of HTGR technology ( $\sim 800$ reactor modules rated at $600 \mathrm{MWt}$ )

- Providing steam, electricity, and high-temperature gas to the process heat market, providing steam, electricity and hydrogen for bitumen recovery, water treatment, and upgrading from oil sands, producing hydrogen for the merchant market, and producing synthetic fuels and feedstock from coal and biomass

- Providing a significant fraction of non-greenhouse-emitting electricity generation on the national electrical grid

- Reducing the importation of $\sim 2.4$ million barrels of imported crude oil per day $(\sim 25 \%$ of the imported oil in 2009); replacing the equivalent in crude oil based gasoline and diesel fuels with synthetic transportation fuels produced from coal

- Implementing a beneficial and efficient use of coal without generating greenhouse gas emissions

- Reducing $\sim 6.5$ trillion scf in natural gas consumption in the United States, per annum

- Reducing $\mathrm{CO}_{2}$ emissions of $\sim 380$ million metric tons per annum (reducing by $\sim 7 \%$ the total $\mathrm{CO}_{2}$ emissions in the United States).

Table ES-1 summarizes the distribution of the HTGR deployments in the potential markets evaluated in this paper.

Table ES-1. Summary of results.

\begin{tabular}{|c|c|c|c|c|}
\hline Item & $\begin{array}{c}\text { Power } \\
\text { Requirement } \\
\text { (MWt) }\end{array}$ & $\begin{array}{c}\text { Number of } \\
600 \text { MWt Modules }\end{array}$ & $\begin{array}{c}\mathrm{CO}_{2} \text { Emissions } \\
\text { Reductions } \\
\text { (million metric tons) } \\
\end{array}$ & $\begin{array}{c}\text { Natural Gas Usage } \\
\text { Reductions } \\
\text { (trillion cubic feet) }\end{array}$ \\
\hline $\begin{array}{l}\text { Co-generation and } \\
\text { process heat }\end{array}$ & 75,000 & 125 & 110 & 2.2 \\
\hline Hydrogen production & 36,000 & 60 & 15 & 0.44 \\
\hline Oil sands & 18,000 & 30 & 23 & 0.41 \\
\hline $\begin{array}{l}\text { Coal/biomass to fuel } \\
\text { and feedstock }\end{array}$ & 249,000 & 415 & 80 to 410 & N/A \\
\hline Electricity generation & 110,400 & 184 & $\begin{array}{l}\sim 150 \text { replacing CCGT* } \\
\text { or } \\
\sim 300 \text { replacing coal } \\
\text { plant }\end{array}$ & $\begin{array}{l}3.4 \text { (if replacing } 150 \\
\text { CCGT units) }\end{array}$ \\
\hline TOTAL & 488,400 & 814 & 378 to 858 & 6.45 \\
\hline
\end{tabular}

A broader based study of strategies for transforming the U.S. energy infrastructure show that the HTGR technology can be an even more significant asset in improving the energy security in the United States (reduce reliance on imported oil), stabilizing energy prices (insulating the price of energy and feedstock from the large variations seen in natural gas prices over the last decade), and reducing $\mathrm{CO}_{2}$ emissions. ${ }^{1}$

Preliminary business models have been formulated and economic evaluations of these business models have been performed to establish the economic viability of these applications. These business models address the fundamental differences in the economics of a nuclear plant, which are sensitive to 
capital recovery, with a fossil fired plant (e.g., natural gas) whose economics are driven primarily by fuel costs. These business models also address, at a preliminary level, the potential differences in the economic criteria and financial parameters that apply to ownership of a nuclear plant versus that of a conventional industrial plant. They also provide flexibility in addressing varying scenarios of nuclear plant and industrial process ownership and operation, (e.g., a likely condition is that the nuclear plant will be operated by an entity with prior experience in operation of a nuclear plant rather than by the industrial plant owner. The industrial plant owner could own all, part, or none of the nuclear plant). These business models and the economic evaluations will evolve as the NGNP Project progresses and business cases for specific applications are developed.

Because of the preconceptual stage of design of the HTGR for these applications, there is large uncertainty in the capital and operating costs of the HTGR plant and, therefore, comparably large uncertainty in the results of the economic evaluations. However, the evaluations show that the HTGR technology can be competitive with traditional fossil fired processes, depending on the assumptions of capital and operating costs, financing, and the potential for governmental policies to put a cost on carbon emissions in the future. However, the real impact of the economic evaluations on the viability of the HTGR technology is not easily addressed generically. The end user of the technology may consider the long-term benefits of the technology such as security and stability in the price of this energy source and shelter from the potential costs of carbon emissions sufficient to justify a higher initial cost for that energy. How to account for this fact is being pursued with the end users and other stake holders in development of the HTGR technology.

To develop confidence in the technical and economic viability of the HTGR technology, the plant designs need to be progressed beyond their current preconceptual status to provide better estimates of performance and costs to construct and operate. The economic factors for financing and pricing of energy over the long operating lifetime of the HTGR plants need to be refined through further discussion with major financial institutions with an energy portfolio, current nuclear plant owners, and major industrial plant owners that can benefit from use of energy from the HTGR.

The NGNP Project is developing updated and more refined economic models for evaluating the viability of the business models for both the HTGR plant and the industrial plant for the processes evaluated to-date and for those for which evaluations are to be completed. As the designs of the HTGR plants evolve, better estimates of the capital and operating costs for these plants will be developed supporting higher confidence levels in the results of the economic models. This will, in turn, improve the confidence in the continuing evaluations of the technical and long term economic viability of HTGR applications. 


\section{FORWARD}

This revision updates the evaluation of the sizes of the following potential markets:

- Co-generation supply of steam, electricity and hot gas to collocated industrial facilities

- Hydrogen supply to the Merchant Market

- Supply of steam, electricity, and hot gas for bitumen recovery and upgrading in oil sands. 


\section{CONTENTS}

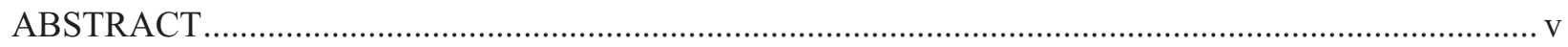

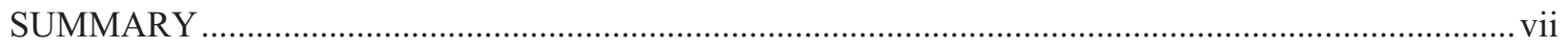

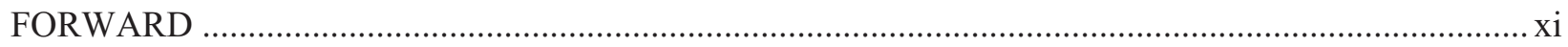

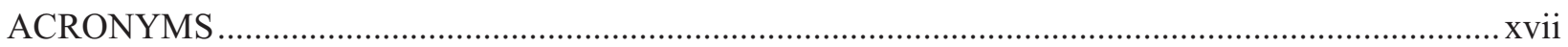

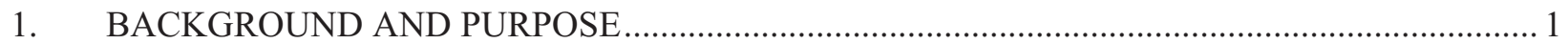

2. ASSESSMENT OF THE HTGR MARKET FOR SUPPLY OF PROCESS HEAT TO THE

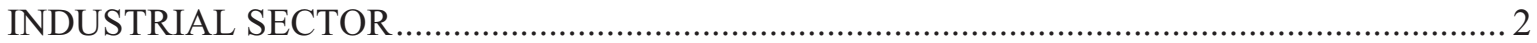

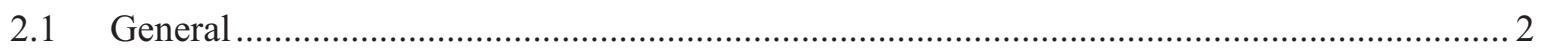

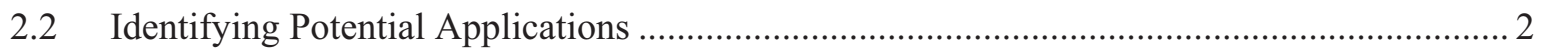

2.3 Characterizing the Potential Market.................................................................................... 3

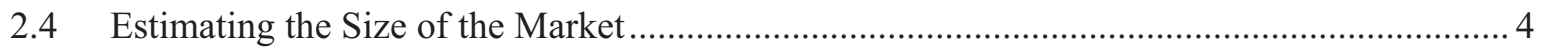

2.4.1 The Cogeneration Market in the United States .......................................................... 5

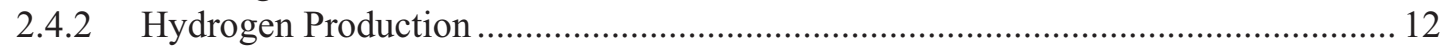

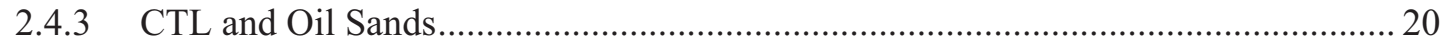

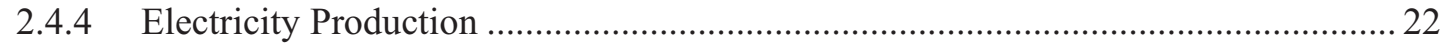

2.4.5 Summary of Deploying HTGR Technology ……................................................ 23

3. SCHEDULE AND BENEFITS TO DEPLOYMENT OF HTGR TECHNOLOGY .....................25

4. TECHNICAL AND ECONOMIC EVALUATIONS OF HTGR TECHNOLOGY INTEGRATION WITH INDUSTRIAL PROCESSES …......................................................... 28

5. BUSINESS CONSIDERATIONS IN APPLYING THE HTGR TECHNOLOGY TO

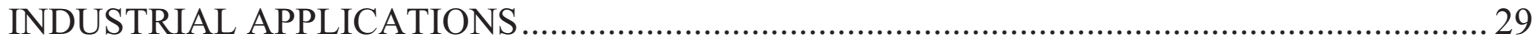

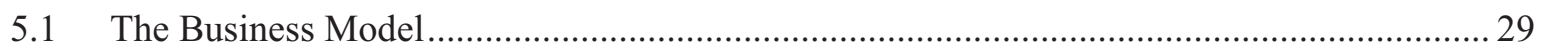

5.2 HTGR Plant Economics versus CCGT Economics .............................................................. 30

5.3 Example of Possible HTGR and Industrial Plant Business Cases ..................................... 30

6. EXAMPLES OF APPLICATION OF THE HTGR TO INDUSTRIAL PROCESSES ................... 32

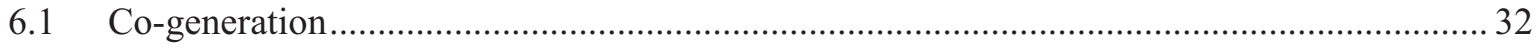

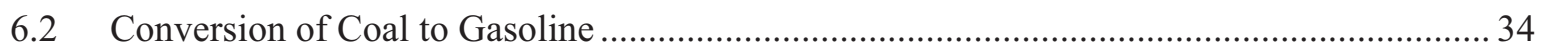

6.3 Integration of the HTGR Technology in an Ammonia Production Plant.............................. 37

6.4 Hydrogen Generation and Effect of Uncertainties on Economic Evaluations ...................... 41

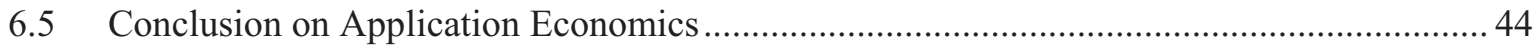

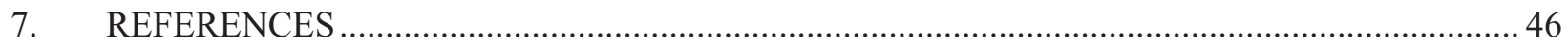

\section{FIGURES}

Figure 1. Process temperature requirements versus LWR and HTGR operating temperatures................... 3 
Figure 2. Projected penetration of the target markets.

Figure 3. Number of CHP facilities ranked by equivalent plant rating (MWt). ...................................... 7

Figure 4. Louisiana 1 cogeneration facility at the Exxon Mobil Baton Rouge Refinery............................ 9

Figure 5. Distribution of required plant ratings for cogeneration plants $>600 \mathrm{MWt}$............................. 10

Figure 6. Equivalent natural gas price versus plant rating. ............................................................... 11

Figure 7. Historical electricity and steam prices as a function of natural gas price (this figure extracted from Excel file, "HTGR Co-gen and Electricity Only Parametric and Tornado

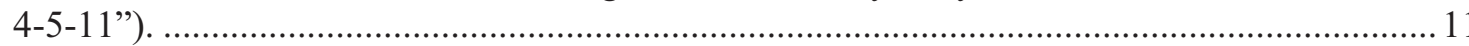

Figure 8. Total and Merchant Hydrogen Production 2005-2010 ........................................................ 14

Figure 9. Merchant and nonmerchant hydrogen production in the United States; 2005 through 2008

Figure 10. Components of hydrogen production using conventional steam methane reforming. .............. 18

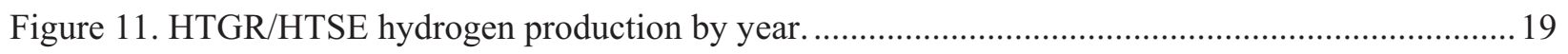

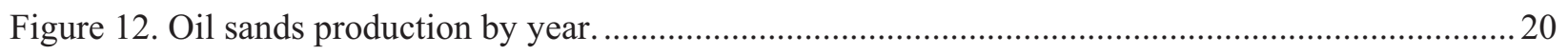

Figure 13. In situ production by year. (Generated in Excel file, "Basis for SAGD Projections in

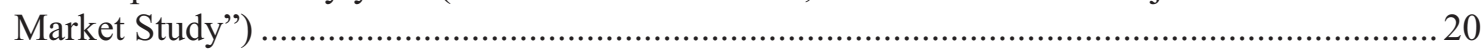

Figure 14. Deploying HTGR technology in the oil sands. (Generated in Excel File, "Backup Calculations for Industrial Energy Emissions \& Consumption \& CTL Plant_8-2-11")

Figure 15. Comparison of life cycle emissions of HTGR based applications with conventional fossil based applications for transportation fuel production..................................................22

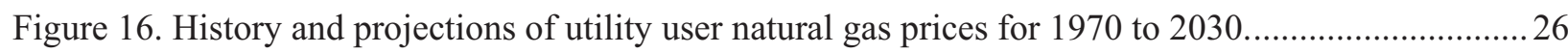

Figure 17. EIA Projections of the Sources of Natural Gas Production through 2035 .............................26

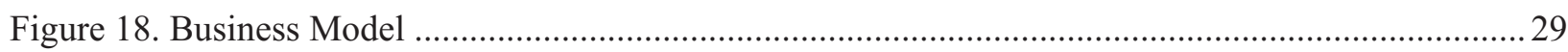

Figure 19. Comparison of the operating cost elements of an HTGR with a CCGT plant.

(Developed in Excel file, "CCGT (7FA) steam \& elec 5-24-11”) ........................................... 30

Figure 20. Comparing the price of electricity and steam for HTGR and NGCC plants (2009\$).

(Developed in Excel file, "Baseline Co-gen Plant - 4-600 MWt_8-04-11”) ............................ 33

Figure 21. Block diagram of conventional coal to MTG process. ........................................................... 35

Figure 22. Block diagram of the HTGR integrated coal to MTG process............................................... 35

Figure 23. Conventional coal-to-MTG process compared with HTGR integrated coal-to-MTG process.

Figure 24. Results of the economic evaluation of conventional and HTGR integrated coal-toMTG plants. (Gasoline price: well to tank; Peak and Low \$/gal between 2000 and 2009, developed in Excel file, "Backup Calcs on Industrial Sector Emissions \& Energy Consumption and CTL Plant").....

Figure 25. Comparison of the production price of gasoline for crude oil refining, conventional coal to MTG and HTGR integrated coal to MTG processes. (Developed in Excel file, "Backup Calcs on Industrial Sector Emissions \& Energy Consumption and CTL Plant"). 
Figure 26. Use of the HTGR instead of natural gas firing in the primary reforming stages. 38

Figure 27. Use of the HTGR for supply of hydrogen directly to the ammonia syntheses reactor. .39

Figure 28. Summary of results for use of the HTGR for ammonia production.

Figure 29. Comparison of conventional and HTGR integrated plant urea pricing vs. costs for $\mathrm{CO}_{2}$ emissions. (Developed in Excel file, "Ammonia Economics - Separating the Process from the HTGR 8-02-10").

Figure 30. Effect of variations in financial parameters on hydrogen pricing. (Developed in Excel file, "HTGR $\mathrm{H}_{2}$ Tornado Chart Development 7-22-10"). .42

Figure 31. Probability distribution of hydrogen pricing. (Developed in Excel file, "HTGR H2 Cost Monte Carlo Analysis using Crystal Ball 6-9-10"). 42

Figure 32. Comparison of hydrogen pricing using SMR and HTGR/HTSE technologies. (Developed in Excel file, "Backup calcs on Industrial Sector \& Emissions and CTL Plant 6-7-10 \& Baseline Hydrogen Plant - 5-600 MWt, 7.57 Kg/sec 8-16-11").

Figure 33, Price of Hydrogen as a Function of Natural Gas Prices for Conventional and HTGRIntegrated Steam Methane Reforming Processes (Developed from Excel file, " $\mathrm{H}_{2}$ from SMR \& SMR w_HTGR Plotting for Presentations" \& Reference 19)

\section{TABLES}

Table ES-1. Summary of results. viii

Table 1. Prioritization of potential industrial applications of the HTGR technology. 2

Table 2. U.S. energy consumption in 2009 \& 2010 by sector. 3

Table 3. Summary of selected industries' energy consumption in the industrial sector.............................. 4

Table 4. Summary data for a cross-section of cogeneration sites in the United States (2009)................... 8

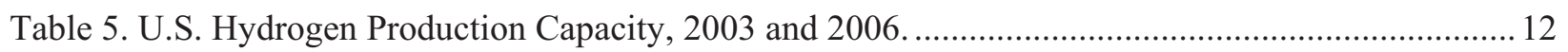

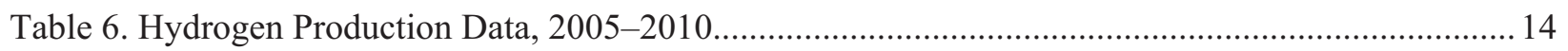

Table 7. Principal merchant hydrogen production companies in the United States. 15

Table 8. Summary of hydrogen production capacity in the United States (Hydrogen Analysis Resource Center: Merchant Liquid and Compressed Gas Hydrogen Production Capacity in the United States and Canada by Company and Location). .16

Table 9. Summary of electrical generating plant costs. .23

Table 10. Summary of results. .23 


\section{ACRONYMS}

$\begin{array}{ll}\text { AEO } & \text { Annual Energy Outlook } \\ \text { CCGT } & \text { Combined Cycle Gas Turbine } \\ \text { DOE } & \text { Department of Energy } \\ \text { EIA } & \text { Energy Information Agency } \\ \text { HTGR } & \text { High-Temperature Gas-Cooled Reactor } \\ \text { HTSE } & \text { High Temperature Steam Electrolysis } \\ \text { INL } & \text { Idaho National Laboratory } \\ \text { LPG } & \text { liquid petroleum gas } \\ \text { LWR } & \text { light water reactor } \\ \text { MTG } & \text { methanol to gasoline } \\ \text { NGNP } & \text { Next Generation Nuclear Plant } \\ \text { SMR } & \text { steam methane reforming }\end{array}$


xviii 


\section{High Temperature Gas-Cooled Reactor Projected Markets and Preliminary Economics}

\section{BACKGROUND AND PURPOSE}

The Next Generation Nuclear Plant (NGNP) Project was initiated at Idaho National Laboratory (INL) by the Department of Energy (DOE) as part of the Generation IV Nuclear Energy Systems technology roadmap and pursuant to the 2005 Energy Policy Act. ${ }^{2}$ The principal objective of the NGNP Project is to support commercialization of high temperature gas-cooled reactor (HTGR) technology. The HTGR is helium cooled with a graphite core that can operate at reactor outlet temperatures much higher than conventional light water reactor (LWR) technology. Accordingly, it can be applied in many industrial applications as a substitute for burning of fossil fuels, such as natural gas, in addition to producing electricity - the principal application of LWRs. Applications of the HTGR technology that have been evaluated by the NGNP Project for supply of process heat include supply of electricity, steam and hightemperature gas to a wide range of industrial processes, and production of hydrogen and oxygen for use in petrochemical, refining, coal-to-liquid fuels and synthetic feedstocks, chemical, and fertilizer plants.

As a non- $\mathrm{CO}_{2}$ emitting substitute for the burning of fossil fuels in industrial applications the HTGR can offset significant quantities of $\mathrm{CO}_{2}$ emissions attendant to the burning of these fuels. These emissions derive from both the direct combustion of these fuels in the industrial processes (e.g., providing steam, electricity for internal use, supplying high temperature gas) as well as the emissions associated with electrical power taken from the grid. This is one of the several benefits of the HTGR technology that have been explored by the NGNP Project with potential end users of this technology in the industrial sector. Several studies have been performed that demonstrate this benefit as well as the technical and economic viability of integrating the HTGR technology with specific applications, (e.g., co-generation of steam, electricity, and high temperature gas; coal-to-liquid transportation fuel conversion; bitumen extraction from oil sands using steam assisted gravity drainage and bitumen upgrading; chemical, ammonia, and ammonia derivative production).

The use of the HTGR technology as a substitute for burning of natural gas in many of these applications and for conversion of coal to synthetic fuels and chemical process feedstock improves the security of the energy supply in the United States by reducing reliance on offshore imports, reduces the impact of the volatility in energy prices that have been experienced over the last few decades on the economics of industrial processes (e.g., wide swings in the prices of oil, natural gas, and coal), and preserves our limited nonrenewable energy resources (e.g., instead of burning natural gas, it is used in more productive and irreplaceable feedstock applications for producing a broad range of chemicals).

This paper summarizes the potential market for HTGR process heat and its environmental benefits in reducing $\mathrm{CO}_{2}$ emissions in these markets and the typical economics of projects in these applications and provides examples of the application of HTGR technology to industrial processes in typical co-generation supply of process heat and electricity, the conversion of coal to transportation fuels and chemical process feedstock, and the production of ammonia as a feedstock for the production of ammonia derivatives, including fertilizer. Finally, the effects of uncertainties in the capital costs and financial factors on the economics of the HTGR technology are demonstrated in application of HTGR and the high temperature steam electrolysis process for the production of hydrogen. 


\section{ASSESSMENT OF THE HTGR MARKET FOR SUPPLY OF PROCESS HEAT TO THE INDUSTRIAL SECTOR}

\subsection{General}

Up to the time of this writing, the assessments of the potential markets and discussions with end users have focused on understanding the full energy needs of the targeted industries to inform the design requirements of the HTGR to meet these needs. As cited above, the targeted markets include established industries, such as co-generation, bitumen extraction from oil sands, and hydrogen production, and new markets such as the conversion of coal to synthetic fuels and feedstock whose development would be enhanced through application of the HTGR technology.

For the purposes of providing a basis for quantifying the benefits of using HTGR technology in these applications, the Project has assumed certain levels of penetration of these markets based on engineering judgment. The following sections summarize the approach applied in this market assessment and the results and conclusions of these assessments.

\subsection{Identifying Potential Applications}

NGNP Project trade studies have identified large, long-term markets that are judged viable for the HTGR technology. These studies first screened the industries to prioritize potential applications as shown in Table 1. ${ }^{3}$ The energy requirements for the low priority industries, (e.g., wood, pulp, paper, textiles, and pharmaceuticals) are judged to not match the capabilities of the HTGR or are not large enough to justify use of a nuclear heat source.

Table 1. Prioritization of potential industrial applications of the HTGR technology.

\begin{tabular}{|c|c|c|}
\hline Industry & Assessment & Priority \\
\hline Petroleum Refining & $\begin{array}{l}\text { Multiple refining processes have very high energy demands and suitable process } \\
\text { temperatures. }\end{array}$ & High \\
\hline Oil Recovery & $\begin{array}{l}\text { In situ bitumen extraction has a high energy demand, suitable process } \\
\text { temperature, and high growth expectations. }\end{array}$ & High \\
\hline $\begin{array}{l}\text { Coal and Natural Gas } \\
\text { Derivatives }\end{array}$ & $\begin{array}{l}\text { Syngas, hydrogen, and liquid fuel production from coal and natural gas has } \\
\text { suitable process temperatures and high projected growth. }\end{array}$ & High \\
\hline Petrochemicals & $\begin{array}{l}\text { Multiple petrochemical production processes have very high energy demands and } \\
\text { suitable process temperatures. }\end{array}$ & High \\
\hline $\begin{array}{l}\text { Industrial Gases } \\
\text { (Hydrogen) }\end{array}$ & $\begin{array}{l}\text { Steam methane reforming and advanced hydrogen production methods have high } \\
\text { energy demands and suitable process temperatures. }\end{array}$ & High \\
\hline $\begin{array}{l}\text { Fertilizers } \\
\text { (Ammonia, Nitrates) }\end{array}$ & Ammonia production has high energy demand and suitable process temperatures. & High \\
\hline Metals & $\begin{array}{l}\text { Direct-reduced iron (DRI) production has high energy demands, suitable process } \\
\text { temperatures and strong global growth. }\end{array}$ & High \\
\hline $\begin{array}{l}\text { Polymer Products } \\
\text { (Plastics, Fibers) }\end{array}$ & $\begin{array}{l}\text { Certain polymers have large energy demands, suitable process temperatures, and } \\
\text { strong global growth. }\end{array}$ & High \\
\hline Cement & $\begin{array}{l}\text { The current cement process temperatures are too high, but production is possible } \\
\text { at suitable temperatures with technology development. }\end{array}$ & Low \\
\hline Pharmaceuticals & $\begin{array}{l}\text { The process energy needs of the pharmaceutical industry on a per plant basis are } \\
\text { relatively low. }\end{array}$ & Low \\
\hline Paper & $\begin{array}{l}\text { The typical energy requirements for a mill is low and byproducts, having little } \\
\text { value otherwise, are burned to provide half of the steam and electricity needs of } \\
\text { paper products. }\end{array}$ & Low \\
\hline Glass & Glass production process temperatures are too high. & Low \\
\hline
\end{tabular}


Figure 1 compares the temperature capabilities of the HTGR with the energy requirements of the higher priority industrial applications and the temperature capabilities of current LWR technologies. This figure shows the broad-based applicability of the HTGR technology in meeting the energy needs of the industrial sector, which cannot be met at the lower temperatures typical of current and advanced LWRs.

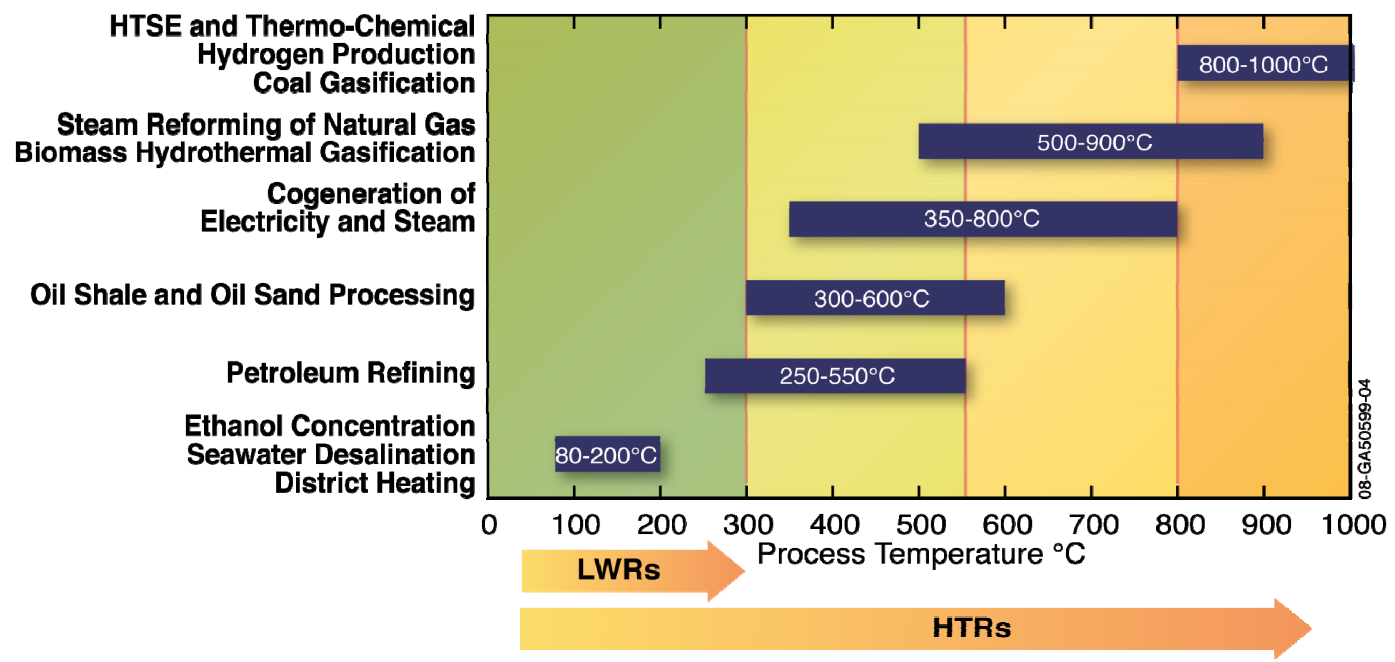

Figure 1. Process temperature requirements versus LWR and HTGR operating temperatures.

\subsection{Characterizing the Potential Market}

The NGNP Project estimated the characteristics and magnitude of the energy needs of selected highpriority processes. The U.S. energy consumption data summarized by the DOE Energy Information Agency (EIA) in Annual Energy Outlook (AEO) reports were used for this purpose. Table 2 shows the energy consumption in the United States by sector in $2009 \& 2010$. This data was obtained from the DOE-EIA AEO 2010 December 2009 update and AEO 2011 Early Release Tables, December $2010 .^{4}$ The applications identified as high and medium priority fall within the Industrial Sector. As shown, this sector was responsible for $\sim 30 \%$ of the energy consumed in 2009 and 2010 . For comparison this is about 3.5 times the total energy generated by the 104 nuclear power plants in the United States in 2009 and 2010 (8.4 quad Btu). The consumption of energy in 2009 by the industries that have been identified as having the highest potential for HTGR application within the Industrial Sector is summarized in Table 3. ${ }^{\mathrm{a}}$ Table 3 Table 2. U.S. energy consumption in 2009 \& 2010 by sector.

\begin{tabular}{|lll|}
\hline \multirow{2}{*}{ Sector } & \multicolumn{2}{c|}{ Quad Btu } \\
\cline { 2 - 3 } & $\mathbf{2 0 0 9}$ & $\mathbf{2 0 1 0}$ \\
\hline Residential & 21.79 & 22.03 \\
Commercial & 18.56 & 18.32 \\
Industrial & 32.2 & 29.91 \\
Transportation & 27.98 & 27.47 \\
\cline { 2 - 3 } \multicolumn{1}{c}{ Total } & 100.53 & 97.73 \\
\hline
\end{tabular}
shows that the refining, chemical processing, iron and steel, aluminum, and plastics industries account for about $40 \%$ of the total energy consumed by the Industrial Sector. Also, about $60 \%$ of the energy consumption for the chemical industry is used for feedstock, typically natural gas. The HTGR could replace chemical industry feedstock by converting synthetic fuel such as coal to synthetic gas. Altogether, these are among the high priority applications identified in the early screening of potential applications for the HTGR technology. As shown in the last two columns of Table 3, except for the Refining sector, the DOE-EIA projections through 2035 show that the Industrial Sector energy consumption is not expected to change significantly (a growth rate of $\sim 0.2 \% /$ annum is projected) over the next 20 years.

a. Table 3 data for 2010 was not available at the time of this writing. It is judged, however, that the relative usage by industry in 2010 would not be significantly different from that in 2009 based on the small change in total industrial energy consumption from 2009 to 2010 as shown in Table 2 . 
Table 3. Summary of selected industries' energy consumption in the industrial sector.

\begin{tabular}{|c|c|c|c|c|c|c|c|c|c|c|c|}
\hline \multicolumn{12}{|c|}{2009 Industrial Sector Energy Consumption (AEO 2010, December 2009) } \\
\hline Total & 28.8 & Quad & \multirow[b]{2}{*}{ Source } & \multirow[b]{2}{*}{$\begin{array}{c}\text { Electricity } \\
\text { Quads }\end{array}$} & \multirow[b]{2}{*}{$\begin{array}{c}\text { Emissions } \\
\mathrm{Mt}\end{array}$} & \multirow{2}{*}{$\begin{array}{c}\% \text { of Total } \\
\text { U.S. } \\
\text { Emissions }\end{array}$} & \multicolumn{2}{|c|}{ On-site Generation } & \multirow{2}{*}{$\begin{array}{l}\text { \# } 600 \mathrm{MWt} \\
\text { modules } \\
\text { equivalent }\end{array}$} & \multirow{2}{*}{$\begin{array}{c}\text { Projected } \\
\text { Annual } \\
\text { Change } \\
2008-2035\end{array}$} & \multirow{2}{*}{$\begin{array}{l}\text { Total } \\
\text { Quads } \\
2035\end{array}$} \\
\hline Industry & $\begin{array}{l}\text { Total, } \\
\text { Quads }\end{array}$ & $\begin{array}{c}\text { \% of Ind } \\
\text { Sector } \\
\text { Total }\end{array}$ & & & & & $\begin{array}{c}\text { Own Use } \\
\text { Elec, } \\
\text { BKWh }\end{array}$ & $\begin{array}{l}\text { Sales to } \\
\text { Grid, } \\
\text { BKWh }\end{array}$ & & & \\
\hline Refining & 3.797 & $13 \%$ & Table 34 & 0.174 & 263.2 & $4 \%$ & 15.97 & 7.4 & 249 & $1.2 \%$ & 5.257 \\
\hline \multirow[t]{2}{*}{ Chemical } & 5.627 & $20 \%$ & Table 37 & 0.404 & 256.7 & $4 \%$ & 43.12 & 9.23 & & $-0.3 \%$ & 5.823 \\
\hline & 2.457 & \multicolumn{7}{|c|}{ used for heat and power the rest is feedstock } & 161 & & 2.515 \\
\hline Iron \& Steel & 0.709 & $2 \%$ & Table 40 & 0.065 & 64.8 & $1 \%$ & 5.53 & 0.82 & 46 & $-1.7 \%$ & 0.842 \\
\hline Aluminum & 0.366 & $1 \%$ & Table 41 & 0.156 & 41.5 & $1 \%$ & 4.57 & 1.6 & 24 & $-0.6 \%$ & 0.299 \\
\hline Plastics & 0.269 & $1 \%$ & Table 43 & 0.155 & 36.2 & $1 \%$ & $\mathrm{~N} / \mathrm{A}$ & $\mathrm{N} / \mathrm{A}$ & 17 & $0.5 \%$ & 0.334 \\
\hline Quad $=1 \mathrm{e} 15 \mathrm{Btu}$ & \multicolumn{6}{|c|}{$M t=$ million metric tons } & \multicolumn{5}{|c|}{ BKWh $=$ billion kilowatt hours } \\
\hline
\end{tabular}

\subsection{Estimating the Size of the Market}

Figure 2 summarizes the projected penetration of the potential markets. The following discusses the development of this figure.

\section{The Opportunity - Integrating Nuclear High Temperature Process Heat with Industrial Applications}

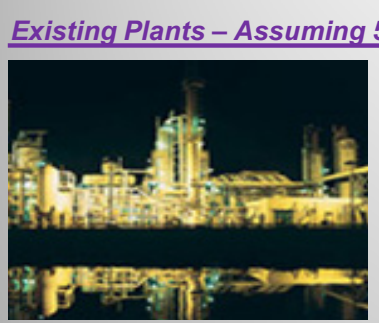

Fertilizers/Ammonia (23 plants in U.S.-NH3 production)

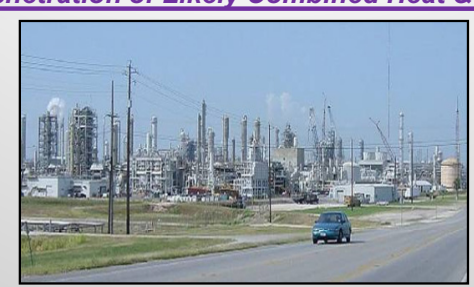

Petrochemical (170 plants in U.S.)

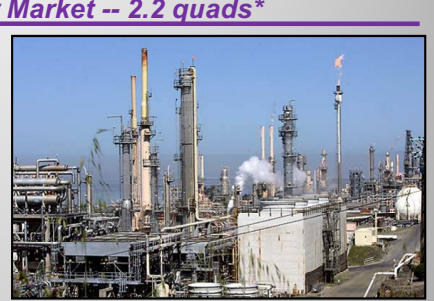

Petroleum Refining (137 plants in U.S.)

Growing and New Markets - Potential for 13.6 quads of HTGR Process Heat \& Power \& Electricity Generation

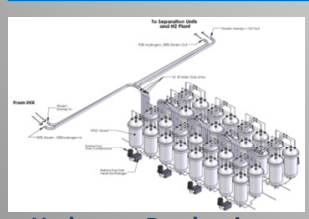

Hydrogen Production 14 - 719 tpd plants

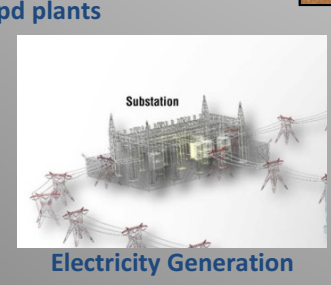

40 GWe capacity

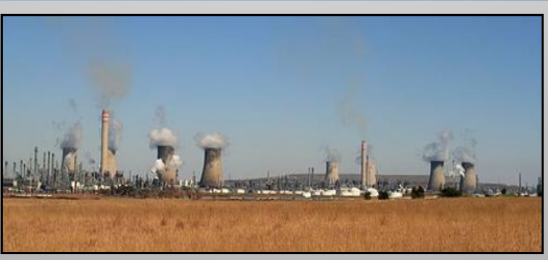

Coal-to-Liquids ( $24-100,000$ bpd plants )

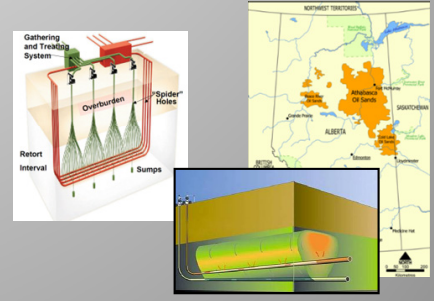

Oil Sands/Shale

27 - 150,000 bpd plants

${ }^{*}$ Quad $=1 \times 10^{15}$ Btu $\left(293 \times 10^{6} M W_{t h}\right)$ annual energy consumption

Figure 2. Projected penetration of the target markets.

The sections that follow identify the specific industries and processes targeted for application of the HTGR technology and summarize NGNP Project estimates of the potential scope for deployment of the HTGR technology as the energy supply for these industries and processes. These start with the co- 
generation and process heat market covering the petrochemical, refining, ammonia/fertilizer production, iron and steel, aluminum, and plastics industries followed by the hydrogen production, oil and oil shale recovery, and conversion of coal to synthetic fuels and feedstock industries. The modular configurations and lower per module rating of the HTGR compared with large LWRs also allow HTGRs to be constructed in areas with limited transmission and distribution capacity, low cooling water availability or other factors that would otherwise be unable to take advantage of nuclear energy. The HTGR also has an advantage over LWRs with a higher thermal efficiency (e.g., 50 to $45 \%$ for the HTGR versus $\sim 30 \%$ for the LWR). Electric generation is, therefore, a potentially important market for the HTGR technology covered below.

\subsubsection{The Cogeneration Market in the United States}

\subsubsection{Data Source}

The U.S. Department of Energy, Energy Information Administration (EIA), 2009 January to December EIA-923 Monthly Time Series File with Sources: EIA-923 and EIA-860 contains the following summary characterization of the sources of data in this file:

This file contains the final 2009 data. During the year, the EIA-923 survey collected monthly data from approximately 1800 generating plants. These data were published each month as preliminary and subject to revision. The remaining out-of-sample power plants reported data annually. In this final 2009 database, the annual responses are proportionately distributed over the months using the ratio of collected monthly data to the sum of that monthly data. The entire set of data collected for 2009 is now final and shown below with plant-specific names and plant numbers. Plants that did not respond or data that could not be verified are estimated. The estimates are rolled-into state/fuel aggregates with a "99999" plant code. For additional information, see the documentation file on page 6 of this workbook.

Of the $\sim 1800$ entries in this database 818 are characterized as combined heat and power (CHP) plants. These are cogeneration plants that provide electricity and in most cases steam to industrial plants. The remaining $\sim 1000$ plants are primarily non-regulated suppliers of electricity to the grid. These latter plants are not considered co-generators for the purposes of this part of the HTGR market analysis. That part of the potential market for HTGR deployment is covered in the assessment of use of the HTGR as an Independent Power Producer (IPP) of only electricity sold to the grid. The full database and an abridged database of the CHP plants only is contained in Excel file "Co-Gen Examples." Manipulation of the data within this file supported the evaluation of the cogeneration market for HTGR application.

The key variables reported in this database used in this analysis included ${ }^{\text {b }}$

- Combined Heat and Power Plant Indicator (only those with a "Y" or "CHP" were used)

- Facility Name

- Operator Name

- State

- Reported Prime Mover, (e.g., steam turbine, gas turbine, gas turbine combined cycle)

- $\quad$ Reported Fuel Type, (e.g., natural gas, mixed gas, coal, products of the process)

- Total Fuel Consumed (MMBtu) - reported monthly

b. The figures and tables in the following discussions were developed using data from this database in Excel File, "Cogen Examples," 8/8/11 
- Year to-date:

- Total Fuel Consumption Quantity

- Electric Fuel Consumption Quantity

- Total Fuel Consumption MMBtus

- Electric Fuel Consumption MMBtus

- Net Generation (megawatthours).

The data collected by EIA in Form 923 covers only that energy consumed in CHP plants that include the generation of electricity and, in most cases, steam that is used by a co-located industrial plant. A fraction of the electricity is typically sold on the regional grid. In a majority of the cases the steam generated by the CHP plant does not cover all of the steam requirements of the industrial facility. These facilities use package or other type boilers that are fired by natural gas and waste gases from the processes to supply the balance of steam demand. EIA does not track the energy consumed by these boilers, but it does track estimated emissions from these plants, although translation of the emissions data into steam demand is not practicable for these purposes. In characterizing and categorizing the size of the CHP plants, this analyses assumed that the relative steam consumption from sources other than the CHP plant to be consistent with the size of the CHP plant. The Project has investigated several specific co-generation applications and this assumption has been confirmed in these investigations.

\subsubsection{CHP Cogeneration Plant Statistics}

A key parameter of interest in assessing the viability of substituting the HTGR technology for the current plants in the cogeneration category is the average annual consumption of energy for each CHP site. For each of the 818 sites the average annual energy consumption (in MMBtus) in 2009 was converted to an average equivalent CHP plant rating assuming a $100 \%$ capacity factor as

Equivalent Plant Rating, MWt = Average Annual Energy Consumption (MMBtus)/3.413 (MMBtus/MWt)/8760 (hours/year).

The Equivalent Plant Ratings (APR) for the 818 sites in 2009 covered the range 3,230 MWt to essentially zero. The zero ratings reflect the fact that some of the smaller plants did not operate much during 2009. For the purposes of this analysis it was assumed that the minimum equivalent average plant rating that may be viable for HTGR application is $600 \mathrm{MWt} .125$ sites had EPRs at or above $600 \mathrm{MWt}$. Figure 3 shows the breakdown of this population of CHP sites by EPR.

Table 4 summarizes data for a limited cross-section of the 818 CHP cogeneration sites in the United States. Not all of these sites are judged to be HTGR applicable. Only 13 of the sites shown in Table 4 are covered by those in Figure 3. The data in Table 4 over the limited cross-section is shown to illustrate why only 125 out of the 818 are considered likely sites for HTGR application-the energy demand is too small. A variety of industrial applications are represented in this table including petrochemical plants, refineries, aluminum smelter, paper mill and biorefinery (see highlighted data). Most of the highlighted plants are part of an industrial facility, but one, (e.g., Louisiana 1) is owned by Entergy and supplies electricity and steam to the Exxon-Mobil Baton Rouge as a cogeneration facility independent from the refinery. This cogeneration plant is shown in relation to the Baton Rouge refinery in Figure 4.

The first 15 of the 22 plants in Table 4 are representative of the 125 sites with equivalent plant ratings $>600$ MWt covered in Figure 3. The final seven are smaller plants shown to provide a broader perspective on the total cogeneration sites in the United States. This table highlights some of the key characteristics of this market:

- Natural gas is the predominate principal fuel followed by coal. 
- The ratio of energy consumed to generate electricity to that used for steam generation is in the mid$40 \%$ range. (Note: the table shows an average of $43.2 \%$ for the 18 plants shown; the average is $45.8 \%$ for the 125 sites that have equivalent plant ratings $>600 \mathrm{MWt}$.

- On average $\sim 25 \%$ of the electricity generated is sold off-site. Note that this is a larger fraction for the off-site "Co-Gen" plants because that is their principal product. Although it is not clearly stated in the EIA data the majority of the electricity is purchased by the co-located industrial facility, (e.g., Midland Cogeneration Venture sells power to a Dow Chemical plant).

- About $17 \%$ of the electricity consumed by the industrial plants comes from the grid. This is usually to make up for insufficient capacity of an onsite plant or if the grid electricity can be obtained for a lower cost than it can be generated onsite. Note that there are plants that do not generate any electricity, (e.g., Ponca City Refinery).

- $\quad$ The peak to average demand for energy was $\sim 120 \%$ in 2009 .

- The average capacity factor for the electricity generation for the facilities listed is $\sim 60 \%$. This was calculated using the nameplate ratings of all of the generators that were statused as operating and the total generation for 2009. The cogeneration facilities tend to have capacity factors higher than this average. The onsite facilities tend to have capacity factors lower than this value. As noted previously, onsite electricity generation may not be used if the electricity can be obtained at a lower price from the grid.

In visits to petrochemical, refinery, and ammonia plants and in discussions with personnel from these sites it was stressed that the steam supply from the cogeneration plants was more important to plant operation than the electricity supply. This is because these plants have ties to the regional grid and can obtain electric power from the grid as needed. That is not the case with steam. $100 \%$ availability of the steam source is required.

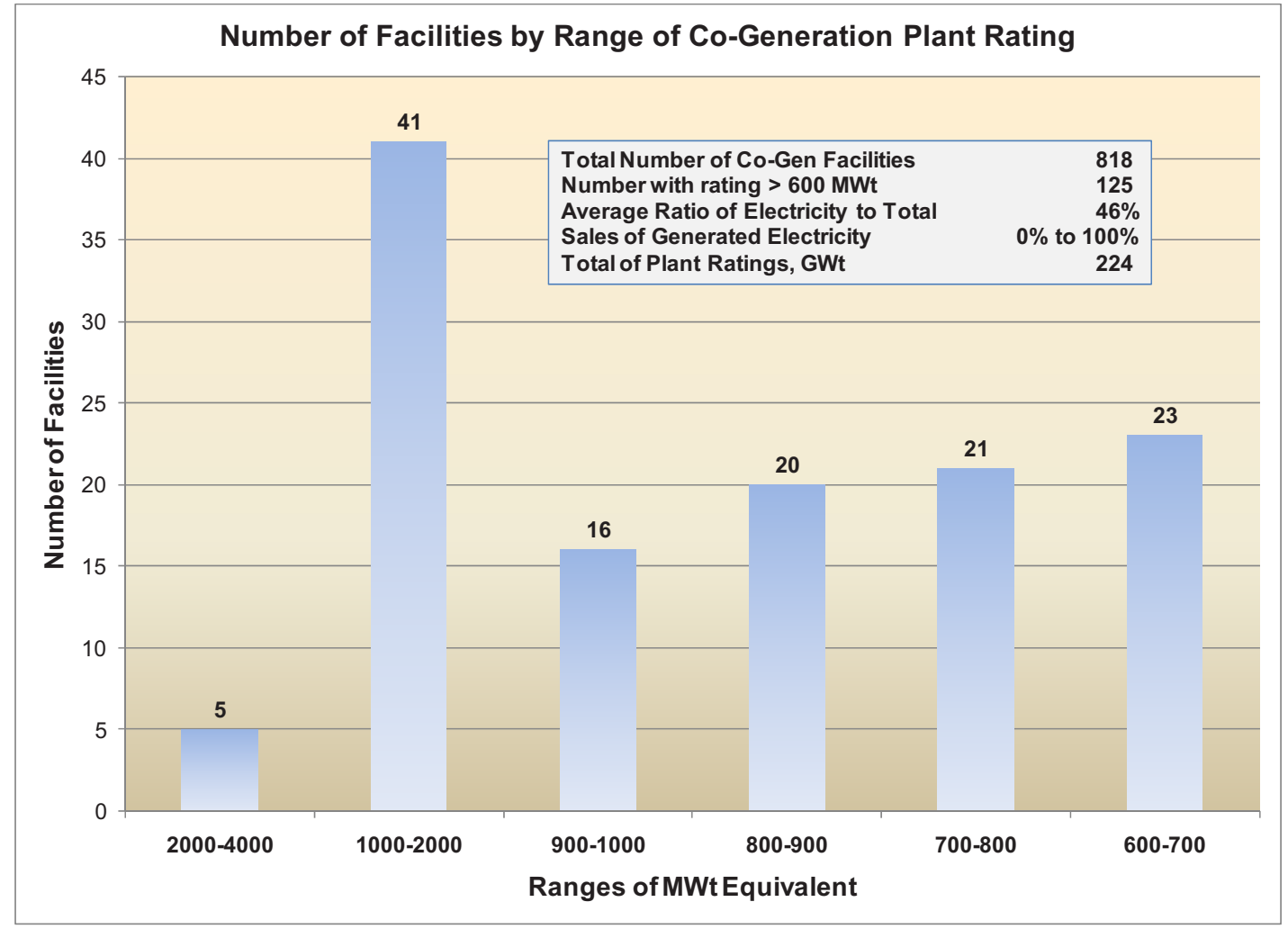

Figure 3. Number of CHP facilities ranked by equivalent plant rating (MWt). 
Table 4. Summary data for a cross-section of cogeneration sites in the United States (2009).

\begin{tabular}{|c|c|c|c|c|c|c|c|c|c|c|c|c|c|c|c|}
\hline Plant Name & Type & $\begin{array}{c}\text { Refinery } \\
\text { Capacity, } \\
\text { Barrels/day }\end{array}$ & Location & $\begin{array}{l}\text { Principal } \\
\text { Fuel }\end{array}$ & $\begin{array}{c}\text { Total } \\
\text { Energy } \\
\text { 2009, } \\
\text { MMBtu }\end{array}$ & $\begin{array}{c}\text { Energy to } \\
\text { Generate } \\
\text { Electricity } \\
2009, \\
\text { MMBtu }\end{array}$ & $\begin{array}{c}\text { Percent } \\
\text { Electricity } \\
\text { Generation, } \\
\%\end{array}$ & \begin{tabular}{|c} 
Percent \\
Electricity \\
Sold Off- \\
Site, \%
\end{tabular} & $\begin{array}{c}\text { Percent } \\
\text { Electricity } \\
\text { from Off- } \\
\text { Site, \% }\end{array}$ & \begin{tabular}{|c|} 
Average \\
Energy \\
Demand, \\
Monthly \\
MWt \\
Equivalent \\
\end{tabular} & \begin{tabular}{|c|} 
Peak \\
Energy \\
Demand, \\
Monthly \\
MWt \\
Equivalent \\
\end{tabular} & $\begin{array}{c}\text { Peak to } \\
\text { Average } \\
\text { Energy } \\
\text { Demand }\end{array}$ & $\begin{array}{c}\text { Peak to } \\
\text { Minimum } \\
\text { Energy } \\
\text { Demand }\end{array}$ & $\begin{array}{c}\text { Ope rating } \\
\text { Electricity } \\
\text { Generator } \\
\text { Ratings }\end{array}$ & $\begin{array}{c}\text { Capacity } \\
\text { Factor }\end{array}$ \\
\hline $\begin{array}{l}\text { Red Shield Environmental Old Town } \\
\text { Facili }\end{array}$ & $\begin{array}{l}\text { Paper Mill/Bio- } \\
\text { refinery }\end{array}$ & N/A & ME & BLQ & $70,259,792$ & 447,234 & $0.6 \%$ & $8.2 \%$ & $22.5 \%$ & 2,958 & 3,217 & 1.09 & 1.19 & 29 & $38 \%$ \\
\hline Alcoa, Warrick & Aluminum & $\mathrm{N} / \mathrm{A}$ & IN & BIT & $47,612,173$ & $47,612,173$ & $100.0 \%$ & $14.4 \%$ & $16.2 \%$ & 1,627 & 1,808 & 1.11 & 1.18 & 778 & $72 \%$ \\
\hline Alcoa, Warrick & Aluminum & & $\mathrm{IN}$ & BIT & $47,612,173$ & $47,612,173$ & $100.0 \%$ & $14.4 \%$ & $16.2 \%$ & 1,627 & 1,808 & 1.11 & 1.18 & 778 & $72 \%$ \\
\hline Dow Chemical Texas Operation & Petro-Chemical & N/A & $\mathrm{TX}$ & NG & $46,235,852$ & $21,322,266$ & $46.1 \%$ & $0.0 \%$ & $39.7 \%$ & 1,568 & 2,029 & 1.29 & 1.81 & 1,011 & $44 \%$ \\
\hline Sweeny Cogen Facility & Co-Gen & 247,000 & $\mathrm{TX}$ & $\mathrm{NG}$ & $40,859,167$ & $16,331,212$ & $40.0 \%$ & $97.6 \%$ & $0.0 \%$ & 1,386 & 1,561 & 1.13 & 1.37 & 572 & $66 \%$ \\
\hline Tennessee Eastman Operations & Petro-Chemical & $\mathrm{N} / \mathrm{A}$ & $\mathrm{TN}$ & BIT & $37,722,726$ & $5,572,342$ & $14.8 \%$ & $0.0 \%$ & $9.5 \%$ & 1,279 & 1,367 & 1.07 & 1.13 & 194 & $69 \%$ \\
\hline ExxonMobil Beaumont Refinery & Refinery & 344,500 & $\mathrm{TX}$ & NG & $36,214,399$ & $21,717,100$ & $60.0 \%$ & $45.2 \%$ & $0.0 \%$ & 1,228 & 1,433 & 1.17 & 1.37 & 670 & $56 \%$ \\
\hline \begin{tabular}{|l} 
Taft Cogeneration Facility \\
\end{tabular} & CoGen & & $\mathrm{LA}$ & $\mathrm{NG}$ & $34,911,384$ & $32,702,872$ & $93.7 \%$ & $68.5 \%$ & $0.0 \%$ & 1,159 & 1,414 & 1.22 & 3.26 & 894 & $59 \%$ \\
\hline Midland Cogeneration Venture & Co-Gen & $\mathrm{N} / \mathrm{A}$ & MI & $\mathrm{NG}$ & $33,090,706$ & $21,407,277$ & $64.7 \%$ & $95.9 \%$ & $0.0 \%$ & 1,120 & 1,646 & 1.47 & 1.93 & 1,469 & $24 \%$ \\
\hline ExxonMobil Baytown Refinery & Refinery & 560,640 & $\mathrm{TX}$ & NG & $59,894,980$ & $27,269,837$ & $45.5 \%$ & $2.6 \%$ & $7.4 \%$ & 1,106 & 1,391 & 1.26 & 1.90 & 552 & $73 \%$ \\
\hline Baytown Energy Center & Co-gen & N/A & $\mathrm{TX}$ & NG & $32,531,570$ & $31,653,775$ & $97.3 \%$ & $0.0 \%$ & $0.2 \%$ & 1,103 & 1,411 & 1.28 & 1.81 & 915 & $49 \%$ \\
\hline \begin{tabular}{|l|} 
Louisiana 1 \\
\end{tabular} & Co-Gen & N/A & LA & $\mathrm{NG}$ & $29,039,100$ & $12,212,758$ & $42.1 \%$ & $13.6 \%$ & $6.2 \%$ & 985 & 1,284 & 1.30 & 1.58 & 250 & $108 \%$ \\
\hline Oyster Creek Unit VIII & Co-Gen & $\mathrm{N} / \mathrm{A}$ & $\mathrm{TX}$ & NG & $27,334,978$ & $22,564,159$ & $82.5 \%$ & $96.7 \%$ & $0.0 \%$ & 927 & 1,014 & 1.09 & 1.23 & 498 & $55 \%$ \\
\hline Dow St Charles Operations & CoGen & & LA & NG & $22,562,622$ & $15,175,000$ & $67.3 \%$ & $17.1 \%$ & $5.0 \%$ & 795 & 864 & 1.09 & 1.20 & 334 & $51 \%$ \\
\hline Eastman Cogeneration Facility & Co-gen & $\mathrm{N} / \mathrm{A}$ & $\mathrm{TX}$ & NG & $20,377,408$ & $12,743,280$ & $62.5 \%$ & $45.8 \%$ & $0.8 \%$ & 691 & 824 & 1.19 & 1.46 & 468 & $50 \%$ \\
\hline Richmond Cogen & Co-Gen & & $\mathrm{CA}$ & NG & $9,897,803$ & $4,537,477$ & $45.8 \%$ & $2.7 \%$ & $6.6 \%$ & 333 & 363 & 1.09 & 1.19 & 125 & $81 \%$ \\
\hline Savannah River Mill & Paper Mill & N/A & GA & NG & $9,739,420$ & $2,789,338$ & $28.6 \%$ & $0.8 \%$ & $9.8 \%$ & 330 & 360 & 1.09 & 1.23 & 90 & $77 \%$ \\
\hline Shell Chemical & CoGen & & LA & NG & $7,952,908$ & $6,441,892$ & $81.0 \%$ & $32.1 \%$ & $1.6 \%$ & 283 & 345 & 1.22 & 1.58 & 80 & $84 \%$ \\
\hline $\begin{array}{l}\text { ExxonMobil Baton Rouge Turbine } \\
\text { Generator }\end{array}$ & Refinery & 504,500 & LA & NG & $6,920,307$ & $2,630,381$ & $38.0 \%$ & $0.0 \%$ & $0.0 \%$ & 235 & 300 & 1.28 & 1.64 & 85 & $78 \%$ \\
\hline Ponca City Refinery & Refinery & 198,400 & $\mathrm{OK}$ & OG & $6,553,764$ & 0 & $0.0 \%$ & $0.0 \%$ & $100.0 \%$ & 222 & 246 & 1.11 & 1.31 & 4 & $0 \%$ \\
\hline \begin{tabular}{|l} 
Port Arthur Refinery-Valero \\
\end{tabular} & Refinery & 232,000 & $\mathrm{TX}$ & $\mathrm{NG}$ & $5,302,388$ & 551,820 & $10.4 \%$ & $6.8 \%$ & $87.7 \%$ & 180 & 222 & 1.23 & 1.53 & 37 & $39 \%$ \\
\hline Richmond Refinery TG800 & Refinery & 245,271 & $\mathrm{CA}$ & OG & $4,806,656$ & 639,995 & $13.3 \%$ & $0.0 \%$ & $0.0 \%$ & 168 & 201 & 1.20 & 1.62 & 30 & $50 \%$ \\
\hline Averages & & & & & $28,974,194$ & $16,087,926$ & $51.6 \%$ & $25.6 \%$ & $15.0 \%$ & 969 & 1,141 & 1.19 & 1.53 & 448 & $59 \%$ \\
\hline
\end{tabular}




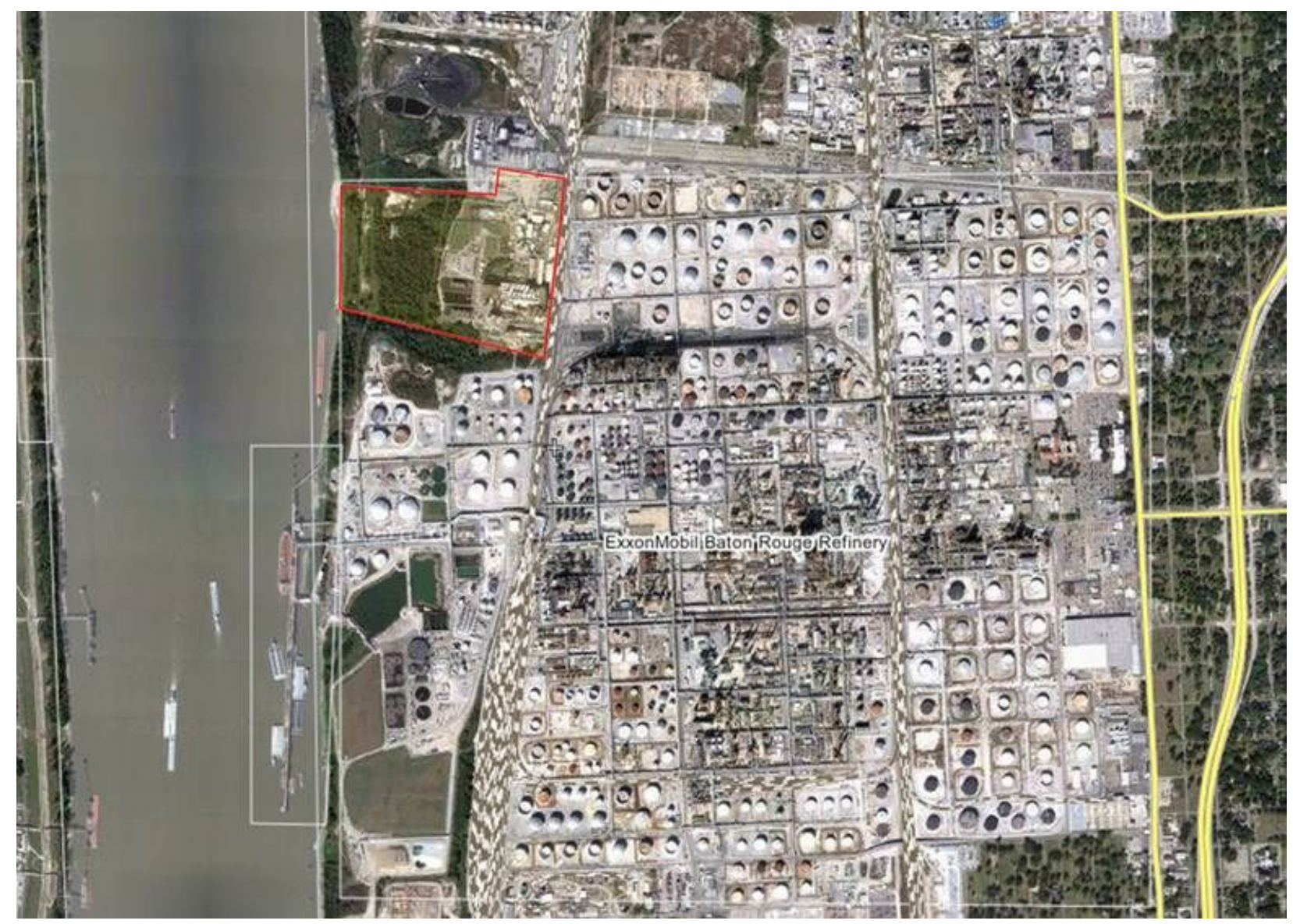

Figure 4. Louisiana 1 cogeneration facility at the Exxon Mobil Baton Rouge Refinery.

Because the data used for this analysis does not necessarily include all of the steam demand for the CHP sites the categorizing the viability of each CHP site by its Equivalent Plant Rating is conservative. There are likely more sites that could be viable for HTGR application. For example, the latter two refineries listed in Table 4 have relatively small CHP facilities but likely have much higher overall energy demand than shown. Accordingly, the co-generation market size projected in this analysis is judged to be conservative.

The data in Table 4 informs needed characteristics of an average HTGR plant that would replace the existing fossil plants in these cogeneration applications:

- The plant must be capable of supplying steam demand at 100\% availability. The steam demand on average is $\sim 55 \%$ of the total energy demand on the CHP plant.

- The peak to average demand of total energy is $\sim 120 \%$; the plant must be sized to meet this swing in demand as a minimum.

- The plant must have the capability of supplying at least $45 \%$ of the energy in the form of electricity. About $25 \%$ of that electricity will be sold off-site. This is the primary mechanism by which the plant will absorb variations in the energy demand from the industrial plant.

- The availability of the plant on an annual basis must take into account outages for refueling, regular maintenance, major maintenance and un-scheduled outages. For an HTGR this is projected to result in an availability of $90 \%$ over the life of the plant. 
These characteristics combine to form a factor that relates the Required Rating of the HTGR plant to the average Equivalent Plant Rating as determined above. This factor includes:

Peak to average $=1.2$

Availability $=1 / 0.9=1.11$

Total $=1.33$

Accordingly, the HTGR plant rating must be one third larger than the average Equivalent Plant Rating as determined above. Figure 5 is a revision of Figure 4 applying this factor. As shown, the combined required plant ratings of the 105 sites at $900 \mathrm{MWt}$ or above is $\sim 156 \mathrm{GWt}$; the balance of $38 \mathrm{GWt}$ is in the range 600 to $900 \mathrm{MWt}$.

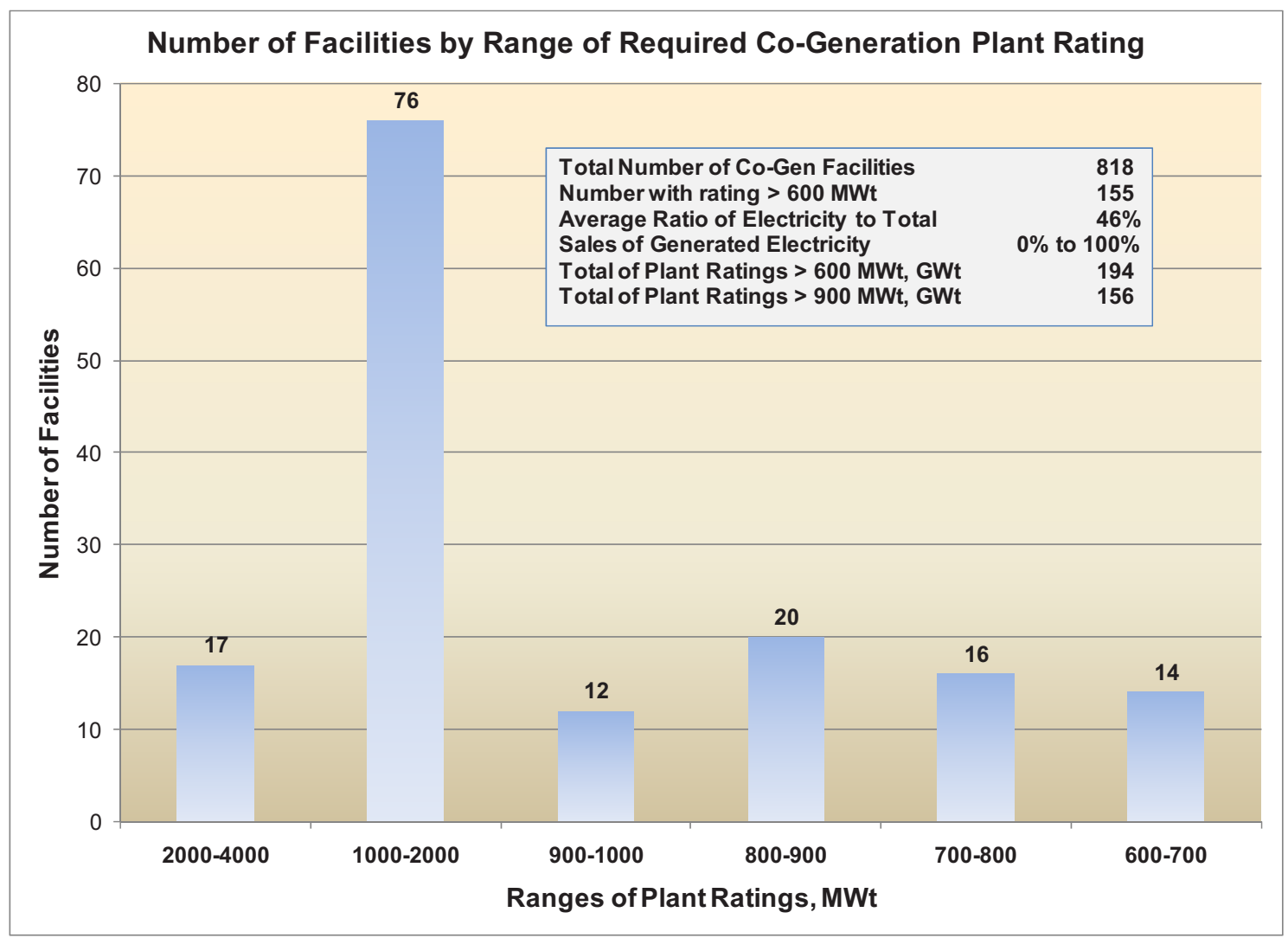

Figure 5. Distribution of required plant ratings for cogeneration plants $>600 \mathrm{MWt}$.

Figure 6 shows the results of estimating the energy prices for an HTGR applied to cogeneration applications of varying plant ratings from 600 to 2,400 MWt using $600 \mathrm{MWt}$ module ratings. Prior analyses have shown that the $600 \mathrm{MWt}$ module rating has economic advantage over smaller module ratings. Figure 6 shows the variation in energy pricing with plant rating as equivalent natural gas price. Equivalent natural gas price is that price at which a conventional natural gas based plant would have the same product price, (e.g., for steam and electricity) as the HTGR plant. Data on actual electricity and steam prices as a function of natural gas price over a wide range of natural gas prices was obtained from General Atomics as part of their development of the Conceptual Design Report for a prismatic reactor based plant (SC-MHR), ${ }^{5}$ see Figure 7. This metric is used since the majority of cogeneration plants currently use natural gas as the primary fuel. The HTGR pricing is also shown for internal rates of return (to the equity holders of the HTGR plants) of 10 and $15 \%$. As shown, equivalent natural gas prices range from $\$ 9.75 / \mathrm{MMBtu}$ for the $600 \mathrm{MWt}$ plant rating and 15\% IRR to $\$ 5.55 / \mathrm{MMBtu}$ for the $2,400 \mathrm{MWt}$ plant rating and $10 \%$ IRR. The curves show a marked reduction in equivalent natural gas price from 600 to 1,200 MWt. The sharp change in slope at 1,200 MWt is due to the coarseness of the intervals of plant rating used in the analysis. However, the trend is judged to be accurate. 


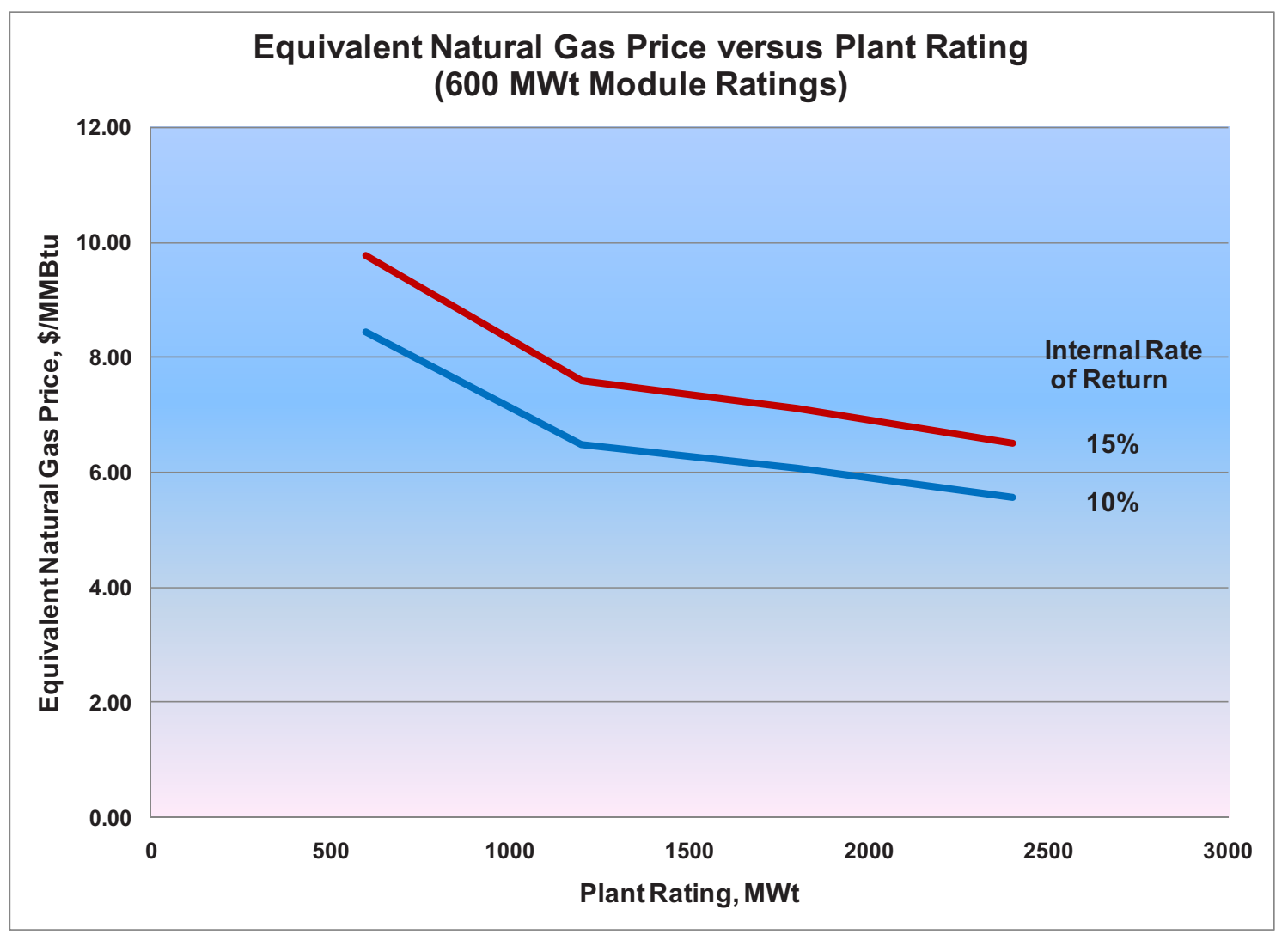

Figure 6. Equivalent natural gas price versus plant rating.

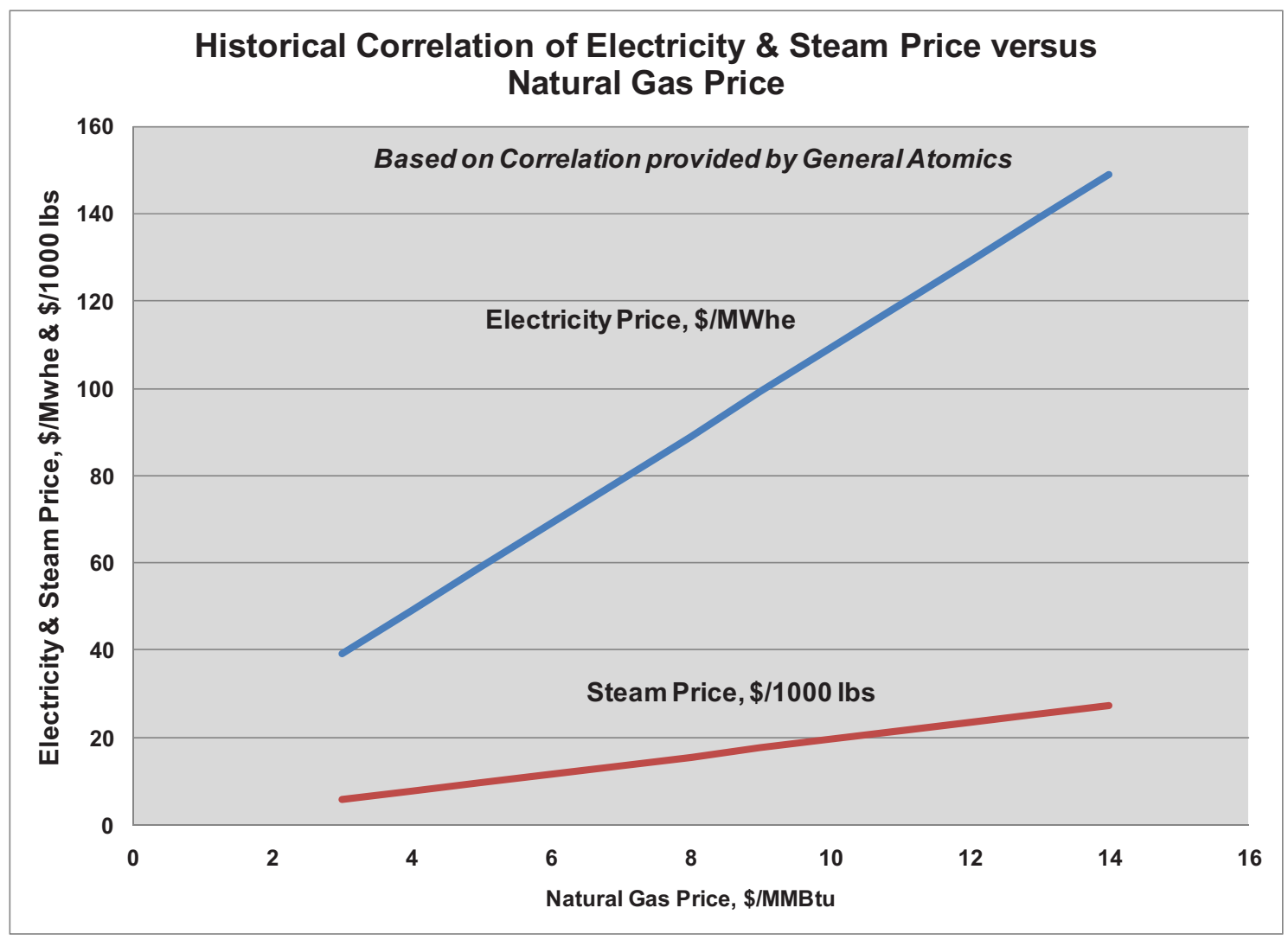

Figure 7. Historical electricity and steam prices as a function of natural gas price (this figure extracted from Excel file, "HTGR Co-gen and Electricity Only Parametric and Tornado 4-5-11"). 
It is judged that without imposition of costs for carbon emissions that the HTGR needs to have projected energy prices in a range equivalent to $\sim \$ 8 / \mathrm{MMBtu}$.

Assuming that Figure 6 is representative of projected prices of HTGR energy as a function of plant rating, the \$8/MMBtu price falls between $\sim 750$ and $\sim 1100 \mathrm{MWt}$ depending on the IRR assumed. It is judged that sites with plant ratings at or above $900 \mathrm{MWt}$ would be economically viable without a carbon cost and are the most likely market for HTGR application. Those between 600 and $900 \mathrm{MWt}$ may require a carbon cost to be competitive and, therefore, may not be viable targets. As shown in Figure 5 the required combined plant rating of the sites at $900 \mathrm{MWt}$ or above is $\sim 156 \mathrm{GWt}$. Assuming that $50 \%$ of these are replaced with HTGR plants the total projected market for HTGR deployment in this area of cogeneration applications is $\sim 75 \mathrm{GWt}$.

\subsubsection{Hydrogen Production}

The HTGR combined with high temperature steam electrolysis (HTSE) is an effective non- $\mathrm{CO}_{2}$ emitting process for producing hydrogen. Demonstration of hydrogen production was cited as an objective for development of the HTGR technology in the Energy Policy Act of 2005.

The majority of the generation and use of hydrogen in the United States is in the refining industry. Based on EIA data, ${ }^{6}$ refineries in the United States had hydrogen generation capacity of 2,985 million cubic feet per day in 2010; equivalent to 2,590 thousand metric tons per year at $100 \%$ capacity factor. This compares with a capacity of 3,100 million cubic feet per day in 2007; equivalent to 2,723 metric tons per year at $100 \%$ capacity factor. Table 5 shows that refinery hydrogen generation was 2,723 thousand metric tons in 2006. This is the last data available that estimates actual generation. In comparison with the capacities in 2007 and in 2010 it is concluded that these refineries run the onsite hydrogen plants essentially at $100 \%$ capacity.

Table 5. U.S. Hydrogen Production Capacity, 2003 and 2006.

\begin{tabular}{|c|c|c|}
\hline \multirow[b]{2}{*}{ Capacity Type } & \multicolumn{2}{|c|}{$\begin{array}{c}\text { Production Capacity } \\
\text { (Thousand Metric Tons per Year) }\end{array}$} \\
\hline & 2003 & 2006 \\
\hline \multicolumn{3}{|l|}{ On-Purpose Captive" } \\
\hline Oil Refinery & 2,870 & 2,723 \\
\hline Ammonia & 2,592 & 2,271 \\
\hline Methanol & 393 & 189 \\
\hline Other & 18 & 19 \\
\hline \multicolumn{3}{|l|}{ On-Purpose Merchant ${ }^{n}$} \\
\hline Otf-Site Refinery & 976 & 1,264 \\
\hline Non-Refinery Compressed Gas (Cylinder and Bulk) & 2 & 2 \\
\hline Compressed Gas (Pipeline) & 201 & 313 \\
\hline Liquid Hydrogen & 43 & 58 \\
\hline Small Reformers and Electrolyzers & $<1$ & $<1$ \\
\hline Total On-Purpose" & 7,095 & 6,839 \\
\hline \multicolumn{3}{|l|}{ Byproduct } \\
\hline Catalytic Reforming at OIl Refineries & 2,977 & 2,977 \\
\hline Other Off-Gas Recovery ${ }^{\mathrm{s}}$ & 462 & 478 \\
\hline Chlor-Alkali Processes & NA & 389 \\
\hline Total Byproduct & 3,439 & 3,844 \\
\hline Total Hydrogen Production Capacity & 10,534 & 10,683 \\
\hline
\end{tabular}

"On-purpose" are those units where hydrogen is the main product, as coposed to "byproduct" units where hydrogen is produced as a result of processes dedicaled to producing other products.

"From membrane, cryogenic and pressure swing adkorption (PSA) units at refineries and other process plants.

Sources: The ElA-820 Refinery Survey. The Census Bureau MA28C and MO325C Industrial Gas Suneys, sRI Consulting. The Innovation Group, Air Products and Chemicals, Bige Yildiz and Argonne National Laboratory (Report in ANL 05/30, July 2005), and ElA analysis. 
As shown in Table 5 ammonia plants also produced significant quantities of hydrogen in 2003 and 2006. However, review of recent data indicates that ammonia plants in the United States have been operating at low capacity factors for several years due to competition from offshore. Ammonia generation is, therefore, not judged to be a viable market for HTGR hydrogen at this time. This market will continue to be evaluated and if it reverses recent trends it will be factored into the market projections.

The potential market for deployment of HTGR technology for hydrogen generation is judged to be the merchant market. As shown in Table 5 merchant plants supplied a little over $20 \%$ of the direct ("onpurpose") generation of hydrogen in 2003 and 2006.

Table 5 was extracted from a 2008 EIA assessment of the effect of hydrogen generation on greenhouse gas emissions. This assessment presented the following conclusions ${ }^{7}$ :

"As illustrated in Figure C.2, the refinery demand for hydrogen is increasing in order to satisfy the growing demand for hydrocarbon transportation fuels and the tightening environmental restrictions on vehicle exhaust emissions. Since 1982, there has been a 59\% expansion of onsite refinery-owned hydrogen plant capacity - an average growth rate of about $1.2 \%$ per year. Prior to 2006 the United States hydrogen industry had been growing at a rate of about 7 to $10 \%$ per year and is projected to grow another $40 \%$ over the next five years. Within the refinery sector, the near-term average annual growth rate of hydrogen consumption is projected to be about $4 \%$ per year. The merchant share of hydrogen to refineries is estimated to grow at an annual rate of about 8 to $17 \%$ per year."

Figure C.2. United States Refinery On-Site Hydrogen Production Capacity

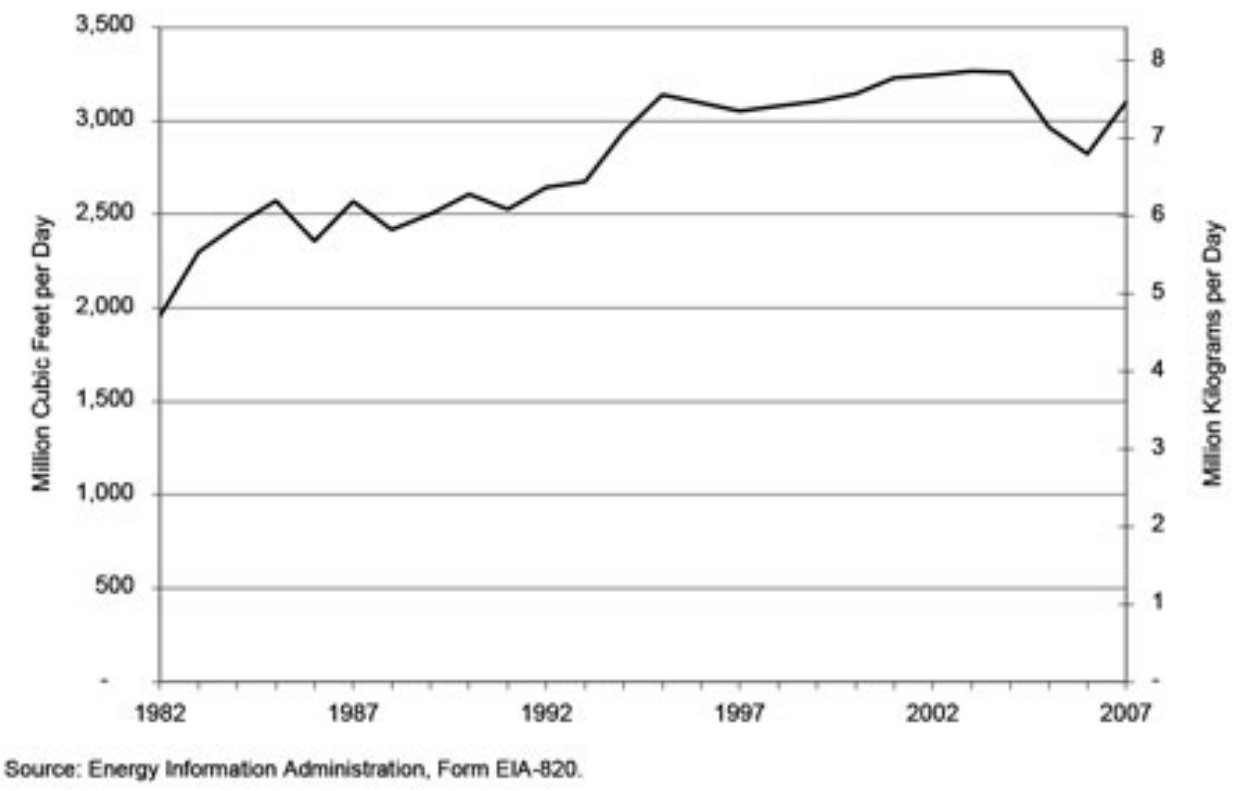

This prediction has, however, not been borne out through 2010, likely because of the downturn in the U.S. economy starting in 2008. Table 6 and Figure 8 show the total and merchant market production of hydrogen worldwide and in the United States for 2005 through 2010. The merchant market accounted for 15 to $20 \%$ of the total U.S. production over this period. Figure 9 shows the industries serviced by the merchant market in 2003 and 2006. The market was dominated by refineries in these years. Based on the location of most of the major producers near refineries (see Table 9) it is judged that this is still the major market for merchant hydrogen production. 
Table 6. Hydrogen Production Data, 2005-2010. ${ }^{\text {a }}$

\begin{tabular}{|c|c|c|c|c|c|c|}
\hline & \multicolumn{6}{|c|}{ Production Figures in Million Metric Tons/Year } \\
\hline & 2005 & 2006 & 2007 & 2008 & 2009 & 2010 \\
\hline Worldwide Total Production $^{\mathrm{b}}$ & 23.158 & 24.098 & 28.917 & 31.327 & 36.146 & 31.327 \\
\hline Worldwide Merchant ${ }^{\mathrm{c}}$ Production & 2.499 & 2.892 & 4.097 & 4.579 & 4.579 & 4.820 \\
\hline U.S. Total Production & 15.447 & 16.145 & 19.037 & 19.760 & 19.760 & 20.122 \\
\hline U.S. Merchant Production & 1.598 & 1.783 & 2.535 & 2.856 & 2.892 & 3.012 \\
\hline U.S. Large Merchant Production & 1.513 & 1.687 & 2.410 & 2.716 & 2.819 & 2.928 \\
\hline U.S. Small Merchant Production & 0.084 & 0.096 & 0.125 & 0.140 & 0.084 & 0.084 \\
\hline \multicolumn{7}{|l|}{ U.S. Small Merchant Delivery Modes } \\
\hline Liquid Tanker & \multicolumn{6}{|l|}{$90 \%$} \\
\hline Compressed Gas Tube Trailer & \multicolumn{6}{|l|}{$7 \%$} \\
\hline Compressed Gas Cylinder & \multicolumn{6}{|l|}{$3 \%$} \\
\hline \multicolumn{7}{|c|}{$\begin{array}{l}\text { a. Source: CryoGas International, February 2006; February 2007; February 2008; February 2009; April 2010; February } 2011 . \\
\text { b. Excludes hydrogen production from syngas, byproduct gases, and onsite plants not owned and operated by the end-user. } \\
\text { c. "Merchant" hydrogen production is defined here to mean any hydrogen produced by one company for consumption by } \\
\text { another company. Large merchant production is usually delivered to the customer via pipeline as a compressed gas. The } \\
\text { merchant plant may be on the customers property, adjacent to the customer's property (commonly referred to as "over the } \\
\text { fence") or a few hundred miles away in regions (e.g., Texas Gulf Coast) served by hydrogen pipeline networks. Merchant } \\
\text { production is a subset of total production. }\end{array}$} \\
\hline
\end{tabular}

\section{$\square$ Total Production $\square$ Merchant Production}

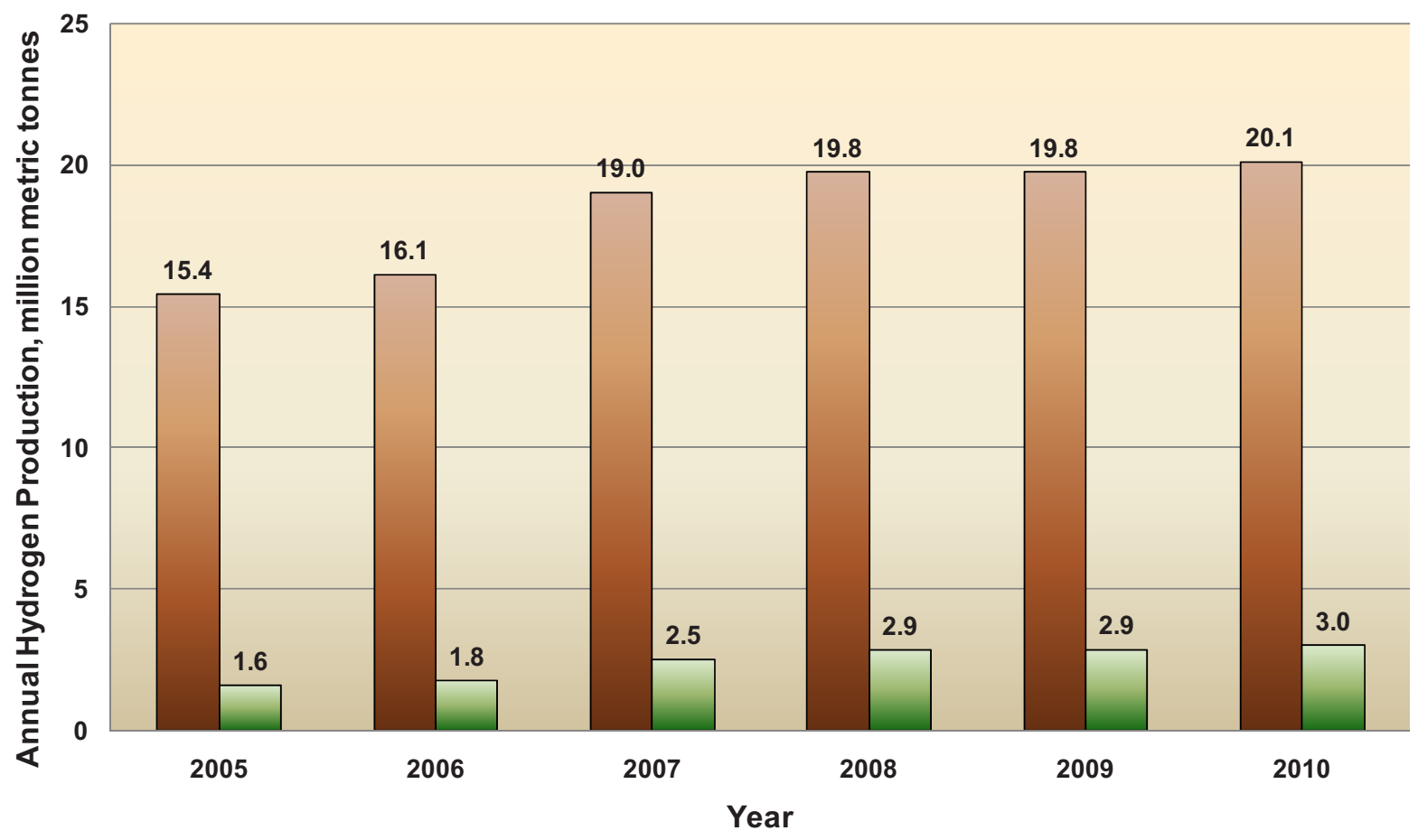

Figure 8. Total and Merchant Hydrogen Production 2005-2010. 


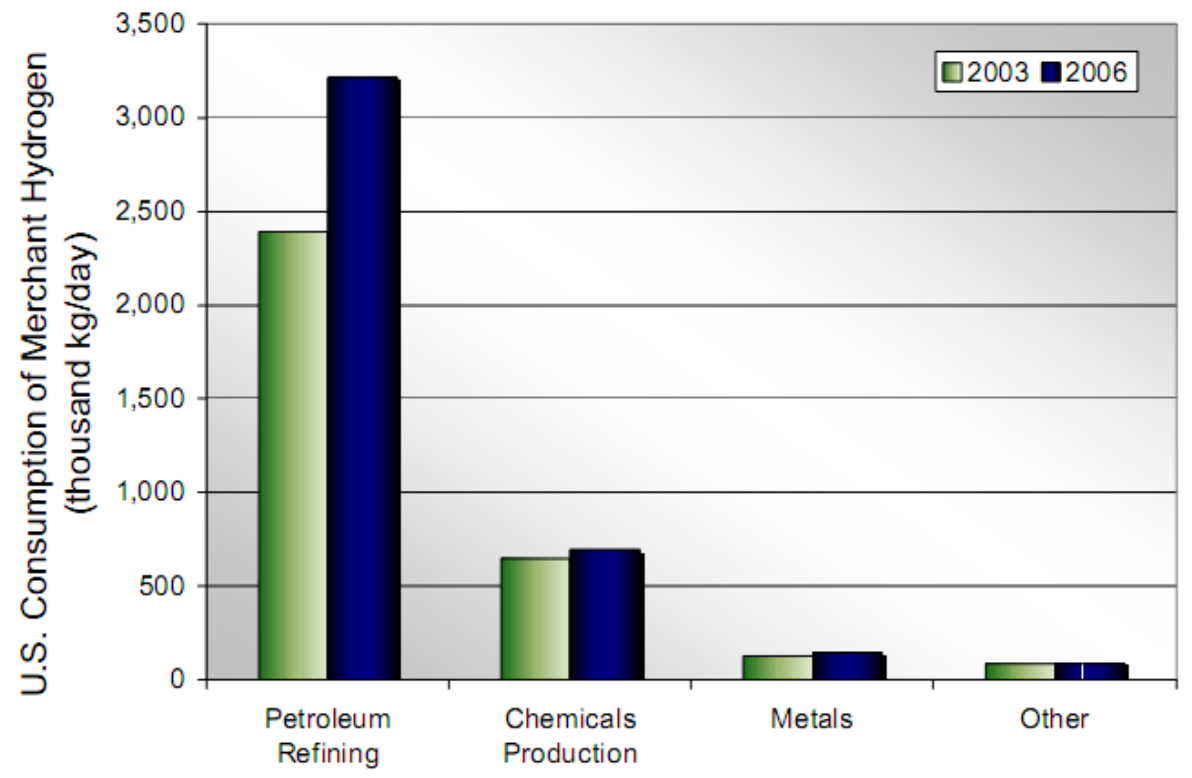

Figure 9. Merchant and nonmerchant hydrogen production in the United States; 2005 through $2008 .{ }^{8}$

Based on data reported by the Hydrogen Resource Center, the merchant market for generation and supply of gaseous hydrogen is dominated by the four U.S. companies shown in Table 7. These four companies account for $97 \%$ of the merchant market hydrogen capacity in the United States. Table 7 , Figure 8, and Table 8 all show a merchant market production rate of $\sim 3$ million metric tonnes in 2010 , reflecting a greater than $100 \%$ capacity factor for that market.

Table 7. Principal merchant hydrogen production companies in the United States.

\begin{tabular}{|c|c|c|}
\hline Company & Capacity, kg/day & $\%$ of Total \\
\hline Air Products & $3,890,347$ & 48 \\
\hline Praxair & $2,532,228$ & 31 \\
\hline Air Liquide & 888,878 & 11 \\
\hline BOC-Linde & 540,803 & 7 \\
\hline \multirow[t]{2}{*}{ TOTAL } & $8,100,481$ & 97 \\
\hline & 2957 & Metric tons/year \\
\hline
\end{tabular}

A significant amount of hydrogen is also produced in the United States as a byproduct of refinery and petrochemical processes. Table 5 showed that byproduct production accounted for 35 to $40 \%$ of the total hydrogen production capacity in 2003 and 2006. It is judged that this percentage has been maintained through 2010.

Steam methane reforming is the principal method used in refineries and by the merchant market to produce hydrogen. INL analyses ${ }^{9}$ show that the ratio of hydrogen produced to natural gas input in the steam reforming process is $\sim 2.5$ and $\sim 25$ tons of $\mathrm{CO}_{2}$ is produced for every million standard cubic feet (Mscf) of hydrogen produced. These analyses also project that $\sim 70 \%$ of the $\mathrm{CO}_{2}$ could be captured and sequestered, see Figure 10.

If it is assumed that $60 \%$ of the hydrogen produced in 2010 ( $\sim 12$ million metric tonnes, $\sim 5 \mathrm{mscf}$ ) was produced using conventional steam methane reforming ${ }^{c} \sim 2$ trillion cubic feet of natural gas were consumed and 115 million metric tons of $\mathrm{CO}_{2}$ were generated.

c. This accounts for that produced from by-products and other processes. 
Table 8. Summary of hydrogen production capacity in the United States (Hydrogen Analysis Resource Center: Merchant Liquid and Compressed Gas Hydrogen Production Capacity in the United States and Canada by Company and Location).

\begin{tabular}{|c|c|c|c|c|c|c|}
\hline Producer & City & $\begin{array}{c}\text { State/ } \\
\text { Province }\end{array}$ & $\begin{array}{l}\text { Capacity } \\
\left(\mathrm{Nm}^{3} / \mathrm{hr}\right)\end{array}$ & $\begin{array}{c}\text { Capacity } \\
\text { (Mscf/day) }\end{array}$ & $\begin{array}{l}\text { Capacity } \\
\text { (kg/day) }\end{array}$ & Year Opened \\
\hline Air Products & Sacramento & $\mathrm{CA}$ & 2,568 & 2,300 & 5,542 & 1986 \\
\hline Air Products & New Orleans & LA & 29,918 & 26,800 & 64,582 & 1966 \\
\hline Air Products & Sarnia & Ontario & 12,838 & 11,500 & 27,712 & 1983 \\
\hline $\mathrm{BOC}$ & Magog & Quebec & 6,586 & 5,900 & 14,218 & 1989 \\
\hline HydrogenAl & Becancour & Quebec & 4,689 & 4,200 & 10,121 & 1987 \\
\hline Praxair & McIntosh & $\mathrm{AL}$ & 12,838 & 11,500 & 27,712 & 1995 \\
\hline Praxair & Ontario & $\mathrm{CA}$ & 9,489 & 8,500 & 20,483 & 1962 \\
\hline Praxair & East Chicago & IN & 12,838 & 11,500 & 27,712 & 1997 \\
\hline Praxair & Niagra Falls & NY & 16,745 & 15,000 & 36,146 & 1982 \\
\hline \multicolumn{3}{|c|}{ Total Merchant Cryogenic Liquid } & 108,508 & 97,200 & 234,229 & \\
\hline Air Gas & Kapolei & HI & 241 & 216 & 521 & 2008 \\
\hline Air Liquide & El Segundo & $\mathrm{CA}$ & 100,015 & 89,592 & 215,896 & 2004 \\
\hline Air Liquide & Rodeo & $\mathrm{CA}$ & 122,797 & 110,000 & 265,074 & 2008 \\
\hline Air Liquide & Honolulu & HI & 8 & 7 & 17 & unknown \\
\hline Air Liquide & Rockport & $\mathrm{IN}$ & 804 & 720 & 1,735 & unknown \\
\hline Air Liquide & Lake Charles & LA & 56 & 50 & 120 & 1957 \\
\hline Air Liquide & Portland & OR & 223 & 200 & 482 & unknown \\
\hline Air Liquide & St. Marys & PA & 324 & 290 & 699 & unknown \\
\hline Air Liquide & Bayport & $\mathrm{TX}$ & 111,634 & 100,000 & 240,976 & 2006 \\
\hline Air Liquide & Corpus Christie & $\mathrm{TX}$ & 55,817 & 50,000 & 120,488 & 1998 \\
\hline Air Liquide & Dallas & TX & 927 & 830 & 2,000 & unknown \\
\hline Air Liquide & Freeport & $\mathrm{TX}$ & 16,745 & 15,000 & 36,146 & 1997 \\
\hline Air Liquide & Ingleside & $\mathrm{TX}$ & 781 & 700 & 1,687 & unknown \\
\hline Air Liquide & La Porte & $\mathrm{TX}$ & 1,116 & 1,000 & 2,410 & unknown \\
\hline Air Liquide & Odessa & $\mathrm{TX}$ & 184 & 165 & 398 & unknown \\
\hline Air Liquide & Anacortes & WA & 23 & 21 & 51 & 2004 \\
\hline Air Liquide & Kalama & WA & 324 & 290 & 699 & unknown \\
\hline Air Products & Edmonton & Alberta & 79,260 & 71,000 & 171,093 & 2006 \\
\hline Air Products & Edmonton & Alberta & 117,215 & 105,000 & 253,025 & 2008 \\
\hline Air Products & Carson & $\mathrm{CA}$ & 111,634 & 100,000 & 240,976 & 1999 \\
\hline Air Products & Martinez & $\mathrm{CA}$ & 139,542 & 125,000 & 301,221 & 1995 \\
\hline Air Products & Wilmington & $\mathrm{CA}$ & 178,614 & 160,000 & 385,562 & 1996 \\
\hline Air Products & Delaware City & $\mathrm{DE}$ & 1,675 & 1,500 & 3,615 & unknown \\
\hline Air Products & Joliet & IL & 20,094 & 18,000 & 43,376 & 2006 \\
\hline Air Products & Tuscola & $\mathrm{IL}$ & 837 & 750 & 1,807 & 1992 \\
\hline Air Products & Butler & IN & 2,009 & 1,800 & 4,338 & unknown \\
\hline Air Products & Catlettsburg & KY & 37,955 & 34,000 & 81,932 & 2004 \\
\hline Air Products & Convent & LA & 122,797 & 110,000 & 265,074 & 2006 \\
\hline Air Products & Geismar & LA & 39,072 & 35,000 & 84,342 & 1999 \\
\hline Air Products & Lake Charles & LA & 111,634 & 100,000 & 240,976 & 2004 \\
\hline Air Products & New Orleans & LA & 44,653 & 40,000 & 96,391 & 2003 \\
\hline Air Products & Plaquemine & LA & 33,490 & 30,000 & 72,293 & unknown \\
\hline
\end{tabular}




\begin{tabular}{|c|c|c|c|c|c|c|}
\hline Producer & City & $\begin{array}{c}\text { State/ } \\
\text { Province }\end{array}$ & $\begin{array}{l}\text { Capacity } \\
\left(\mathrm{Nm}^{3} / \mathrm{hr}\right)\end{array}$ & $\begin{array}{c}\text { Capacity } \\
\text { (Mscf/day) }\end{array}$ & $\begin{array}{l}\text { Capacity } \\
\text { (kg/day ) }\end{array}$ & Year Opened \\
\hline Air Products & Taft & LA & 23,443 & 21,000 & 50,605 & 1995 \\
\hline Air Products & West Lake & LA & 111,634 & 100,000 & 240,976 & 2004 \\
\hline Air Products & Midland & MI & 837 & 750 & 1,807 & 2000 \\
\hline Air Products & Hannibal & MO & 1,072 & 960 & 2,313 & unknown \\
\hline Air Products & Cincinnati & $\mathrm{OH}$ & 2,568 & 2,300 & 5,542 & unknown \\
\hline Air Products & Sarnia & Ontario & 89,307 & 80,000 & 192,781 & 2006 \\
\hline Air Products & Gallatin & $\mathrm{TN}$ & 837 & 750 & 1,807 & unknown \\
\hline Air Products & Baytown & $\mathrm{TX}$ & 78,144 & 70,000 & 168,683 & 2006 \\
\hline Air Products & Clear Lake & $\mathrm{TX}$ & 30,141 & 27,000 & 65,064 & unknown \\
\hline Air Products & LaPorte & $\mathrm{TX}$ & 58,049 & 52,000 & 125,308 & 1996 \\
\hline Air Products & Mont Belvieu & $\mathrm{TX}$ & 32,374 & 29,000 & 69,883 & unknown \\
\hline Air Products & Pasadena & $\mathrm{TX}$ & 89,307 & 80,000 & 192,781 & 1997 \\
\hline Air Products & Port Arthur & $\mathrm{TX}$ & 117,215 & 105,000 & 253,025 & 2001 \\
\hline Air Products & Port Arthur & $\mathrm{TX}$ & 122,797 & 110,000 & 265,074 & 2006 \\
\hline Air Products & South Charleston & WV & 4,019 & 3,600 & 8,675 & unknown \\
\hline BOC-Linde & Decatur & $\mathrm{AL}$ & 11,163 & 10,000 & 24,098 & unknown \\
\hline BOC-Linde & Mobile & $\mathrm{AL}$ & 11,163 & 10,000 & 24,098 & 2007 \\
\hline BOC-Linde & New Castle & $\mathrm{DE}$ & 1,675 & 1,500 & 3,615 & unknown \\
\hline BOC-Linde & Honolulu & HI & 8 & 7 & 17 & unknown \\
\hline BOC-Linde & Lemont & IL & 16,745 & 15,000 & 36,146 & 2003 \\
\hline BOC-Linde & Crawfordsville & IN & 1,206 & 1,080 & 2,603 & unknown \\
\hline BOC-Linde & Lima & $\mathrm{OH}$ & 14,177 & 12,700 & 30,604 & 2000 \\
\hline BOC-Linde & Lima & $\mathrm{OH}$ & 22,327 & 20,000 & 48,195 & 2006 \\
\hline BOC-Linde & Toledo & $\mathrm{OH}$ & 133,960 & 120,000 & 289,172 & 2006 \\
\hline BOC-Linde & Asbestos & Quebec & 7,875 & 7,055 & 17,000 & 2000 \\
\hline BOC-Linde & Salt Lake City & UT & 29,025 & 26,000 & 62,654 & 2006 \\
\hline BOC-Linde & Weirton & WV & 1,206 & 1,080 & 2,603 & unknown \\
\hline Markwest Javelina & Corpus Christi & $\mathrm{TX}$ & 39,072 & 35,000 & 84,342 & unknown \\
\hline Equistar & Channelview & TX & 89,307 & 80,000 & 192,781 & unknown \\
\hline General Hydrogen & Proctor & WV & 558 & 500 & 1,205 & unknown \\
\hline Holox & Augusta & GA & 447 & 400 & 964 & unknown \\
\hline Industrial Gas Products & Sauget & IL & 1,675 & 1,500 & 3,615 & unknown \\
\hline Praxair & Richmond & $\mathrm{CA}$ & 290,247 & 260,000 & 626,539 & 2008 \\
\hline Praxair & Norcross & GA & 4,443 & 3,980 & 9,591 & unknown \\
\hline Praxair & Seymour & IN & 848 & 760 & 1,831 & 1998 \\
\hline Praxair & Whiting & IN & 22,327 & 20,000 & 48,195 & 2006 \\
\hline Praxair & Geismar & LA & 106,052 & 95,000 & 228,928 & 1997 \\
\hline Praxair & Lake Charles & LA & 140,658 & 126,000 & 303,630 & 1999 \\
\hline Praxair & Westlake & LA & 39,072 & 35,000 & 84,342 & unknown \\
\hline Praxair & Ecorse & MI & 1,608 & 1,440 & 3,470 & unknown \\
\hline Praxair & Butte & MT & 324 & 290 & 699 & unknown \\
\hline Praxair & Belvidere & NJ & 480 & 430 & 1,036 & unknown \\
\hline Praxair & West Leechburg & $\mathrm{PA}$ & 2,143 & 1,920 & 4,627 & 1995 \\
\hline Praxair & Channelview & $\mathrm{TX}$ & 44,653 & 40,000 & 96,391 & unknown \\
\hline Praxair & La Porte & $\mathrm{TX}$ & 27,908 & 25,000 & 60,244 & unknown \\
\hline
\end{tabular}




\begin{tabular}{|lllrrrc|}
\hline \multicolumn{1}{|c}{ Producer } & \multicolumn{1}{c}{ City } & \multicolumn{1}{c}{$\begin{array}{c}\text { State/ } \\
\text { Province }\end{array}$} & $\begin{array}{c}\text { Capacity } \\
(\mathrm{Nm} / \mathrm{hr})\end{array}$ & $\begin{array}{c}\text { Capacity } \\
(\text { Mscf/day })\end{array}$ & $\begin{array}{c}\text { Capacity } \\
(\mathrm{kg} / \text { day })\end{array}$ & Year Opened \\
\hline Praxair & Mont Belvieu & TX & 32,374 & 29,000 & 69,883 & unknown \\
Praxair & Port Arthur & TX & 111,634 & 100,000 & 240,976 & 2004 \\
Praxair & Texas City & TX & 111,634 & 100,000 & 240,976 & 2004 \\
Praxair & Texas City & TX & 111,634 & 100,000 & 240,976 & 2006 \\
Praxair & Texas City & TX & 77,027 & 69,000 & 166,274 & 2000 \\
Praxair & Texas City & TX & 44,653 & 40,000 & 96,391 & 1996 \\
Praxair & Belle & WV & 3,349 & 3,000 & 7,229 & unknown \\
Prime Gas & Delaware City & DE & 223 & 200 & 482 & unknown \\
Tessenderlo & Westlake & LA & 39,072 & 35,000 & 84,342 & unknown \\
T\&P Syngas Supply & Texas City & TX & 44,653 & 40,000 & 96,391 & 1996 \\
Total Merchant Compressed Gas & & $3,752,591$ & $3,361,525$ & $8,100,481$ & \\
Total Merchant Product & & & $3,861,098$ & $3,458,725$ & $8,334,711$ & \\
\hline
\end{tabular}
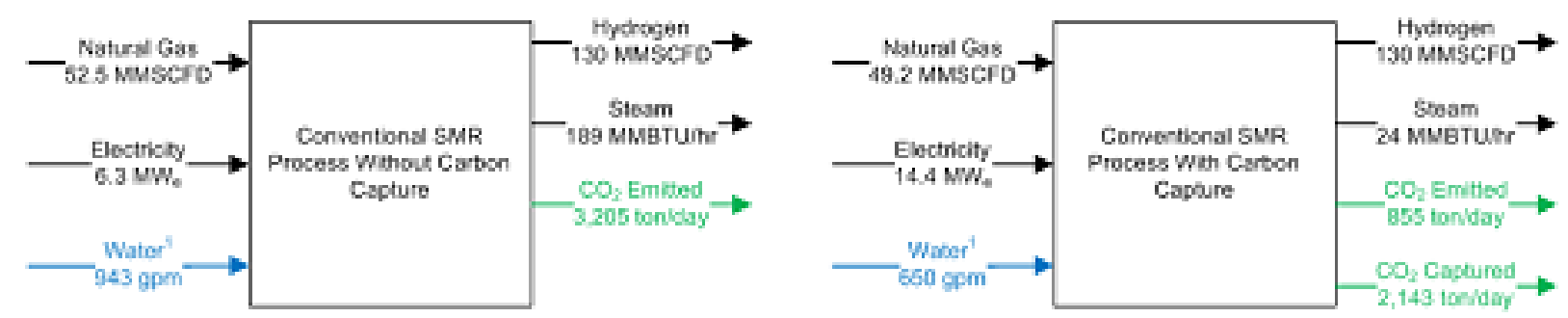

Figure 10. Components of hydrogen production using conventional steam methane reforming.

The HTGR/HTSE plant produces hydrogen with no emissions and with no natural gas fired conserving this limited natural resource for more productive uses such as feedstock for petrochemical processing.

It is assumed that as the economy recovers and for the reasons cited in the 2008 EIA assessment report the $4 \%$ per annum increase in refinery consumption of hydrogen will resume and the merchant market will attain the 8 to $17 \%$ projected growth rate. The assumption on the growth rate for the merchant market is also considered justified because none of the analyses cited so far consider the potential for an expanded use of hydrogen as a transportation fuel. The 2008 EIA report evaluated scenarios for penetration of the light duty vehicle market with fuel cell vehicles that projected hydrogen consumption in the 2030 to 2050 range of 2 to 14 quads $^{\mathrm{d}}$ per annum. This is equivalent to 15 to $75 \%$ of the total hydrogen production in 2010. The shift to hydrogen as a transportation fuel has not proceeded as quickly as has been projected by the 2008 EIA report or by others, (e.g., National Hydrogen Association, DOE) because of the economics of distributing the hydrogen on a scale comparable to gasoline today. However, the high and volatile prices of gasoline over the last few decades, including the recent increase into the $\$ 4 /$ gallon range, provide incentives to develop viable alternative transportation fuels that are not subject to the volatility of crude oil. Hydrogen will likely be one of several alternatives that will emerge to take the place of gasoline over the next few decades; along with hybrid vehicles, electric cars, cellulosic ethanol, etc. A non-greenhouse emitting source of hydrogen will be a key element in supporting hydrogen in this market.

For the purposes of analysis it is assumed that the hydrogen merchant market will grow at a rate of $5 \%$ per year. The HTGR/HTSE process will be applied in about half of the projected growth of the merchant market - 5\% per year. A total merchant market growth rate of 5\% from 2006 to 2020 and 
beyond would project a merchant market of $\sim 3$ million metric tons per year in 2020. If the HTGR/HTSE process was deployed at a rate such that $25 \%$ of this market was supplied by HTGR/HTSE production within the first 10 years of deployment (2020 to 2030) and then continued at that percentage of the market through 2050, 36,000 MWt of HTGR/HTSE technology ( $\sim 60$ reactor modules rated at $600 \mathrm{MWt}$ ) would need to be deployed over the 2020 to 2050 time frame. Figure 11 shows the HTGR/HTSE annual production by year over this deployment period.

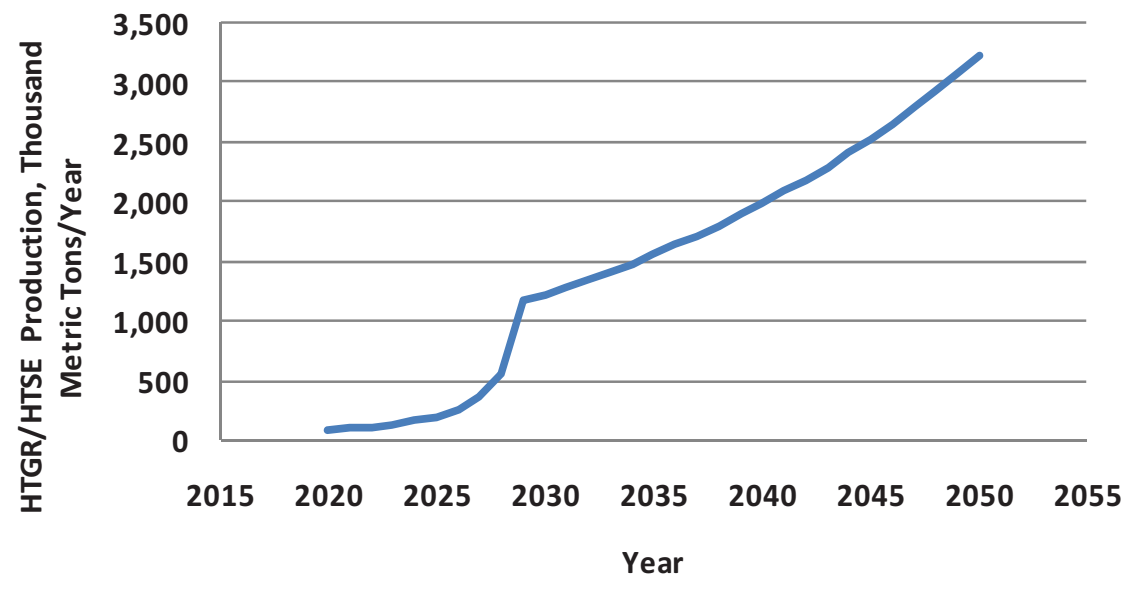

Figure 11. HTGR/HTSE hydrogen production by year.

Since, as noted above, the SMR process consumes $\sim 2.9$ tons of natural gas and generates $\sim 4.7$ tons of $\mathrm{CO}_{2}$ for every ton of hydrogen produced, ${ }^{10}$ the application of the HTGR/HTSE process as a substitute for SMR for this annual rate of production would reduce the natural gas consumption by $\sim 10$ million tons and reduce $\mathrm{CO}_{2}$ emissions by $\sim 15$ million tons per annum in 2050. Over the 30-year period (2020 to 2050) the assumed deployment of the HTGR/HTSE technology for SMR production of hydrogen would have reduced $\mathrm{CO}_{2}$ emissions by $\sim 220$ million metric tons and natural gas consumption by $\sim 135$ million tons ( $\sim 5.9$ trillion scf).

As an alternative to use of the HTGR to support HTSE hydrogen production, INL has performed analyses that show benefit in the use of HTGR heat as a substitute for natural gas firing in the SMR process. ${ }^{9}$ In this application HTGR high temperature heat is substituted for natural gas firing in the primary and secondary reformers. In the application natural gas usage is reduced by 12 to $15 \%$ and emissions by 15 to $40 \%$. The range of reductions reflects an option of including carbon capture and sequestration in the HTGR/SMR process. These reductions in natural gas consumption and $\mathrm{CO}_{2}$ emissions are much lower than achievable by applying the HTGR/HTSE process. However the HTGR energy requirements are also much lower than required to support HTSE; $\sim 90 \%$ lower. If the same level of penetration of the merchant hydrogen market as assumed for the HTSE process is assumed for the HTGR/SMR process by 2050, only 4 GWth of HTGR energy would be required; equivalent to 7- 600 MWt HTGR modules. The total $\mathrm{CO}_{2}$ reductions would be 20 to $30 \%$ of that achievable with HTSE and the reduction in natural gas usage for hydrogen production would be minimal.

Use of the HTGR in support of hydrogen production in the SMR process could be technically and economically viable in selected applications when the energy supplied to the SMR process is part of a facility that is providing energy to other applications in other forms such as steam and electricity. If the application of HTGR energy is to have a major impact on emissions reductions and on reducing natural gas usage in the merchant hydrogen market, it must be combined with either the HTSE or other hydrogen production process that have no emissions and do not use natural gas. 


\subsubsection{CTL and Oil Sands}

As noted previously, there are additional applications for the HTGR technology in emerging industries. These include production of transportation fuels and feedstock from coal, natural gas, and biomass, and enhanced oil recovery from oil sands and oil shale.

\subsubsection{Oil Sands}

The HTGR technology can be applied for steam production in support of steam assisted gravity drainage (SAGD) extraction of bitumen from the Canadian oil sands, treatment of the water extracted with the bitumen, upgrade of the bitumen to synthetic crude using hydrogen generated by the HTGR plant, and electricity production. The Canadian Association of Petroleum Producers projects an increase in oil sands production in the 2015 to 2025 time frame as shown in Figure 12. ${ }^{9}$ In situ (SAGD) production is expected to dominate this growth and result in an increase from 500,000 bpd (barrels per day) in 2015 to $\sim 2,000,000 \mathrm{bpd}$ in 2025 as shown in Figure 13. If the latter rate of increase $(\sim 50,000 \mathrm{bpd}$ for years 2022 to 2025) of in situ production is maintained, this process will be producing 3,250,000 bpd by 2050.

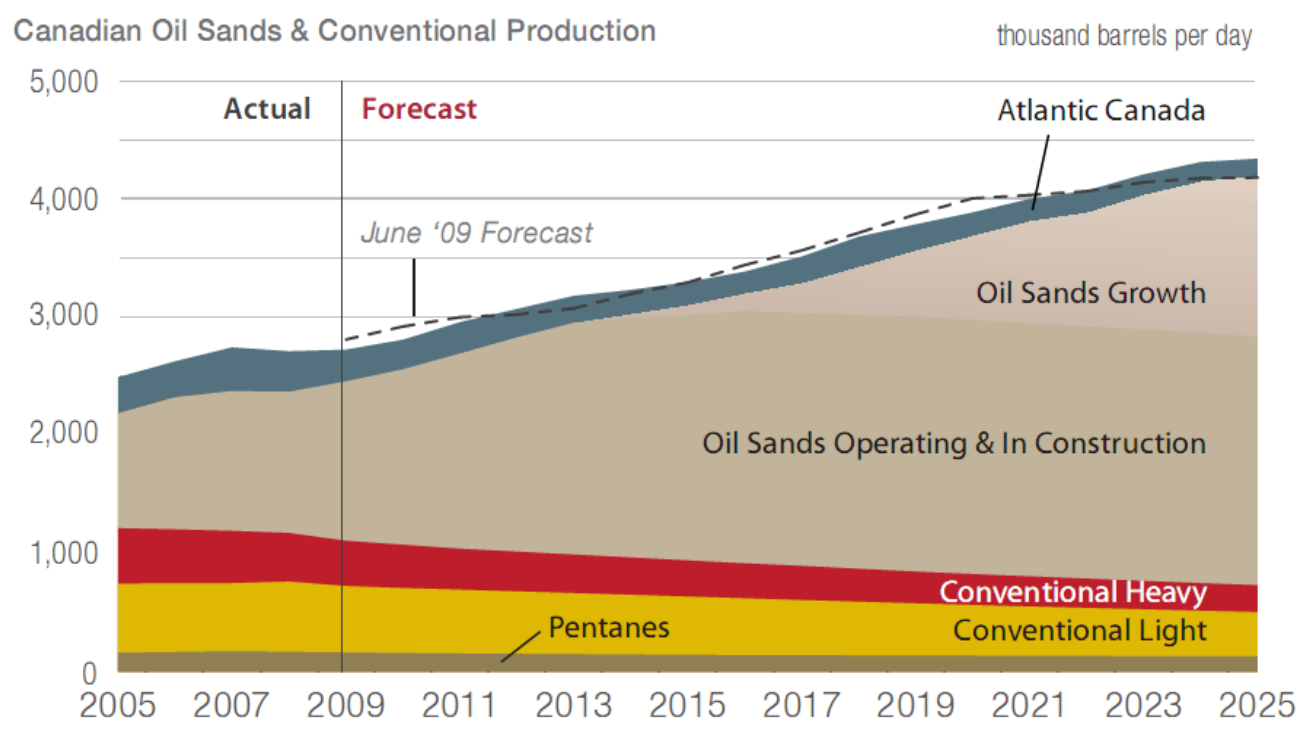

Figure 12. Oil sands production by year.

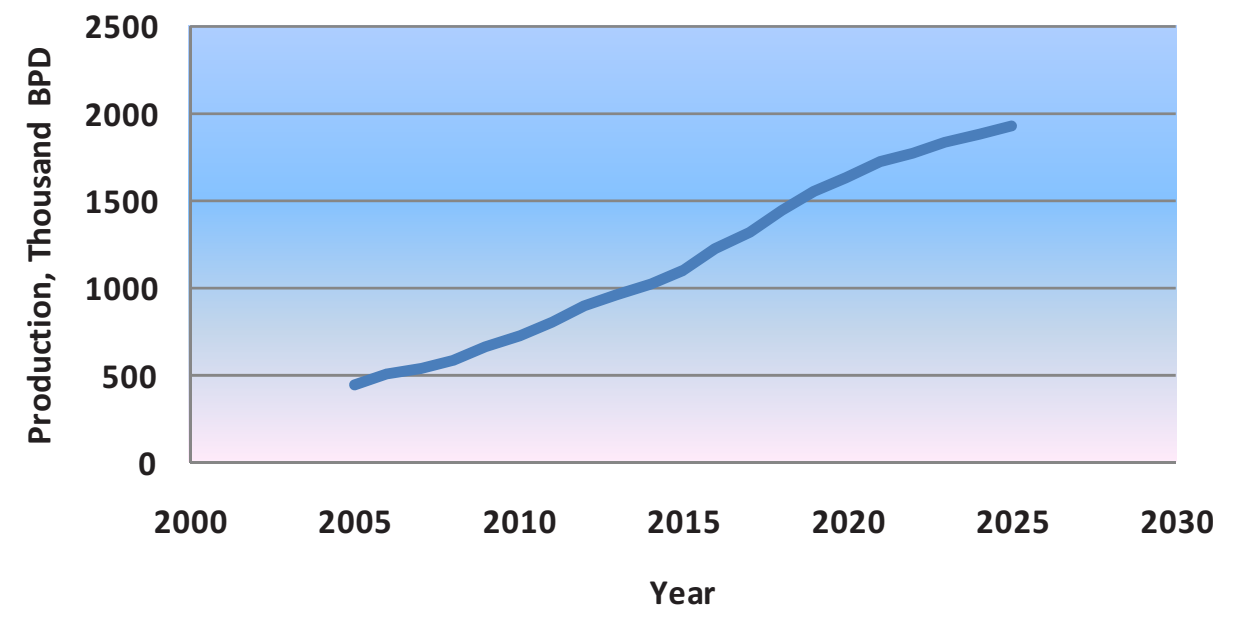

Figure 13. In situ production by year. (Generated in Excel file, "Basis for SAGD Projections in Market Study") 
At the time of this writing the NGNP Project is evaluating the application of the HTGR technology for supply of the energy requirements for bitumen recovery, water treatment, upgrading and electricity supply to the oil sands area. ${ }^{11}$ The objectives of this study are (1) to establish the technical and functional requirements for a central energy supply facility that would perform these functions, (2) confirm that the HTGR technology functional and performance requirements are sufficient to supply these energy needs, and (3) develop a notional HTGR central energy supply plant design to fulfill these requirements. The preliminary results show that it is technically feasible to site such a plant in areas of the oil sands with rich bitumen reserves sufficient to utilize the energy supply from this plant for bitumen extraction, water treatment, bitumen upgrading and electricity generation for at least 60 years.

For the purposes of analysis it was assumed that deployment of these centralized HTGR plants will begin in 2020 and by 2030 will account for supply of $25 \%$ of the projected energy consumption in the oil sands. This level of energy supply ( $25 \%$ of consumption) will be maintained as oil sands production and energy consumption increases through 2050 . This would result in deployment of $\sim 18,000 \mathrm{MWt}$ of HTGR technology or 30 reactor modules rated at $600 \mathrm{MWt}$ by 2050 . Figure 14 shows the projected HTGR deployment strategy along with the projected growth in the oil sands production through 2050 .

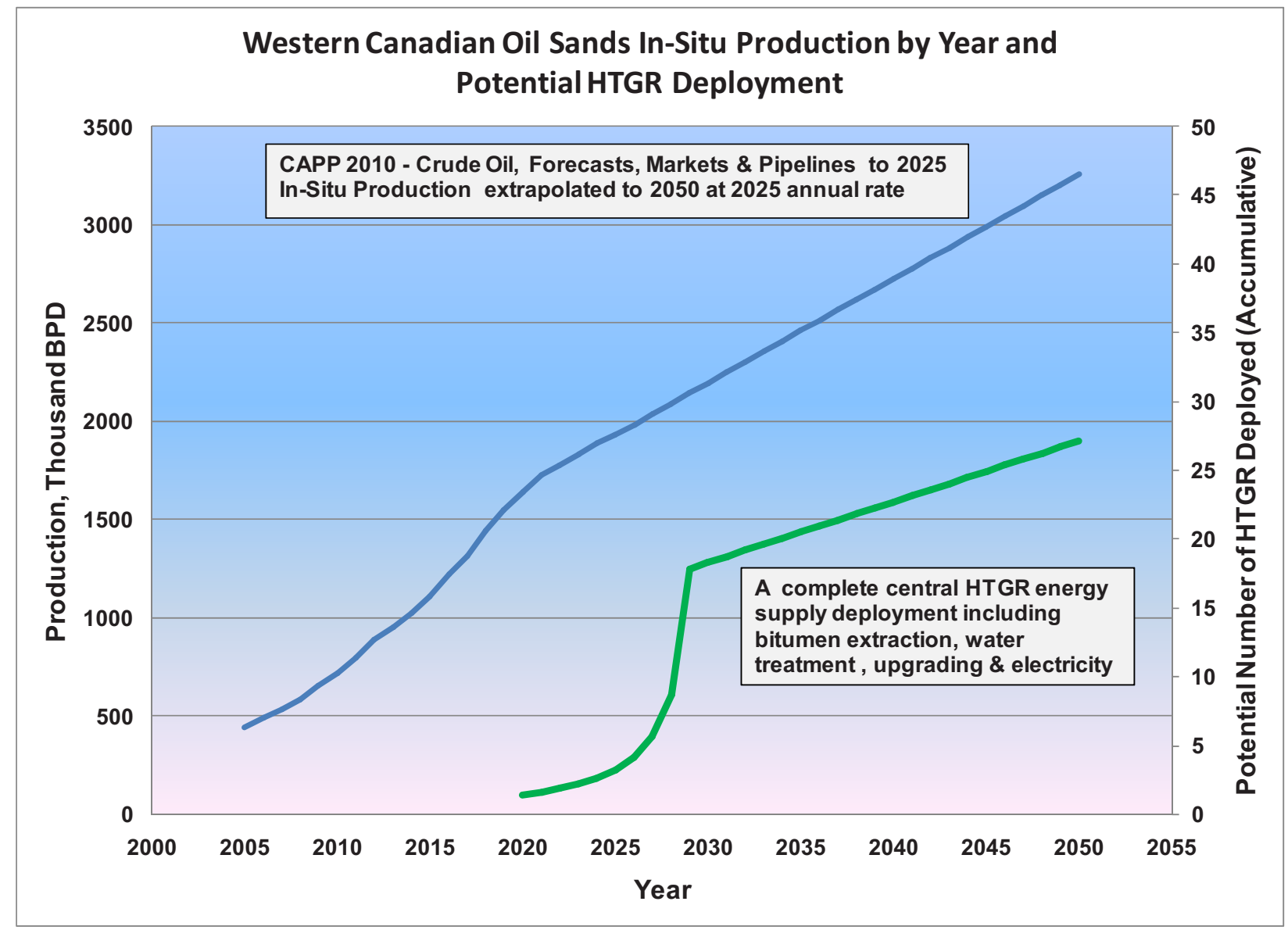

Figure 14. Deploying HTGR technology in the oil sands. (Generated in Excel File, "Backup Calculations for Industrial Energy Emissions \& Consumption \& CTL Plant_8-2-11")

By 2050 this deployment of the HTGR technology would reduce $\mathrm{CO}_{2}$ emissions by $\sim 23$ million metric tons and natural gas consumption by 406 billion scf per year.

There was no comparable estimate available for support of oil shale oil recovery at the time of this writing. This is a potential market yet to be defined. 


\subsubsection{Coal to Synthetic Fuel and Feedstock Production}

If synthetic fuels and feedstock production is to make a significant contribution to improving energy security, it is assumed that it should offset at least $25 \%$ of the current U.S. imports of crude oil. Based on DOE-EIA data, the United States imported 9.12 million barrels of crude oil per day in 2009. Offsetting $25 \%$ of this would require, for example, deployment of twenty-four 100,000 bpd coal/biomass-to-liquid fuel plants, which would require $249,000 \mathrm{MWt}$ (415 reactor modules rated at $600 \mathrm{MWt}$ ) of HTGR energy to supply the energy and hydrogen required by these plants. In comparison with conventional crude oil refining, this would reduce $\mathrm{CO}_{2}$ emissions by $\sim 80$ million metric tons per annum. ${ }^{1}$ In comparison to a conventional coal to liquids plant, the use of the HTGR technology would reduce $\mathrm{CO}_{2}$ emissions by 410 million metric tons per annum with a carbon conversion efficiency of more than $90 \%$ compared with a $\sim 35 \%$ carbon efficiency of the conventional plant. ${ }^{12}$ Figure 15 compares the life cycle emissions for conventional crude oil refining, a conventional coal-to-liquids plant, and an HTGR coalto-liquids plant.

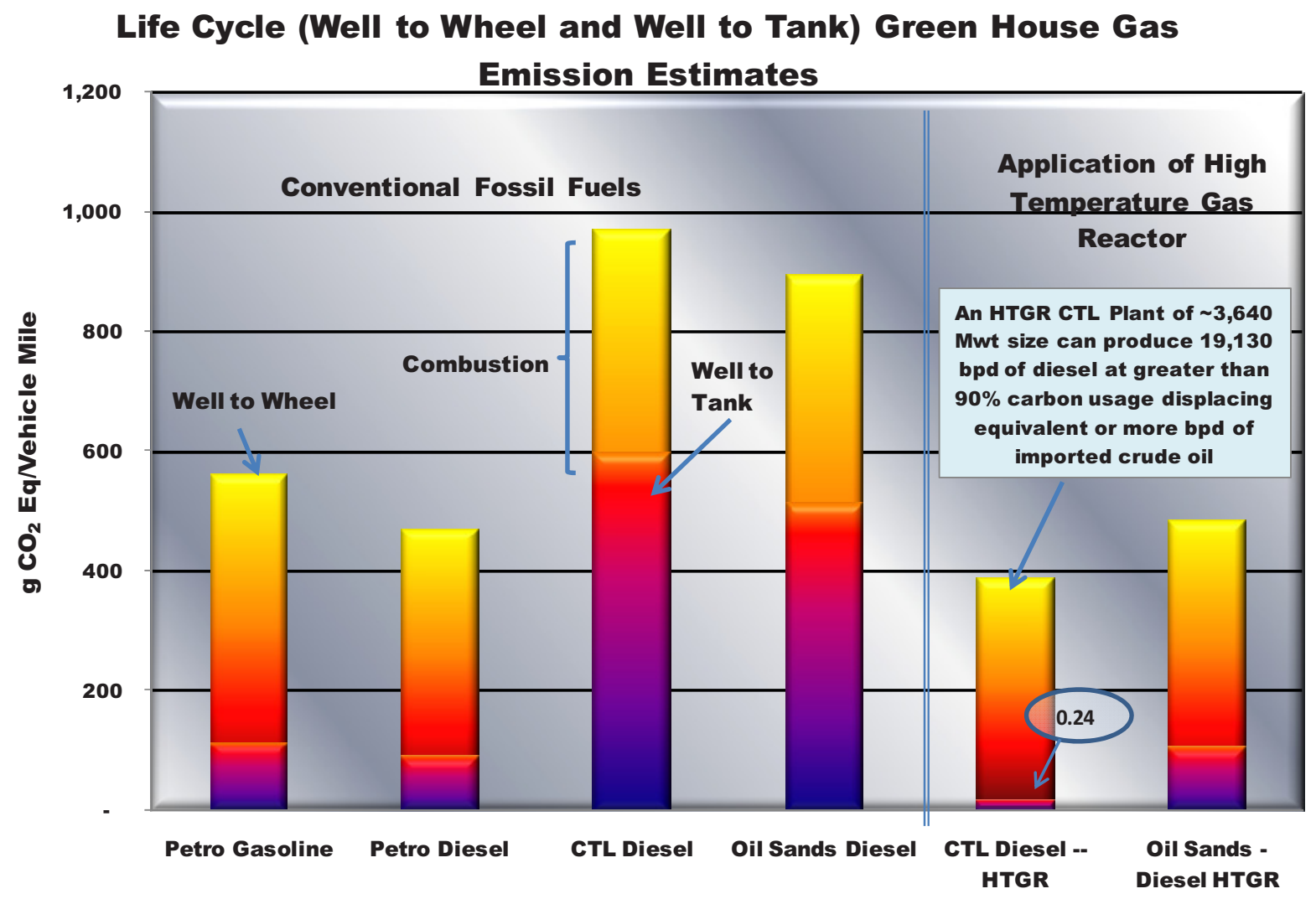

Data for processing using conventional fossil fuels was obtained from DOE/NETL -2009/1346, DOE/NETL-2007/1260 \& 1298, DOE/NETL-2001, data for the HTGR was developed by INL and contractors for the NGNP Project Source file "Nuclear-Fuels Hybrid Calculation R04_09_09", Chart Revision 0, 4/9/09

Figure 15. Comparison of life cycle emissions of HTGR based applications with conventional fossil based applications for transportation fuel production.

\subsubsection{Electricity Production}

Table 9 summarizes data from DOE-EIA on the costs of several forms of electricity production. ${ }^{13}$ As is discussed in detail below the HTGR is competitive with LWRs and other non-greenhouse emitting sources of electricity production. Reference 13 shows that nuclear power will need to play a significant role if the government takes actions to reduce $\mathrm{CO}_{2}$ emissions from electrical production on the national grid. An addition of up to $450 \mathrm{GW}(\mathrm{e})$ of nuclear power has been projected by 2050 in Reference 9 and in EPA assessments of the impact of pending Congressional energy legislation ${ }^{13}$ to meet government emissions reduction objectives. 
Table 9. Summary of electrical generating plant costs. ${ }^{13}$

\begin{tabular}{|c|c|c|c|c|c|c|c|c|c|}
\hline Technology & $\begin{array}{c}\text { Nominal } \\
\text { Capacity } \\
\text { (kilowatts) }\end{array}$ & $\begin{array}{l}\text { Heat Rate } \\
\text { (Btu/kWh) }\end{array}$ & $\begin{array}{c}\text { Overnight } \\
\text { Capital Cost } \\
(2010 \\
\$ / \mathrm{kWe})\end{array}$ & $\begin{array}{c}\text { Fixed O\&M } \\
\text { Cost (2010 } \\
\$ / k W e)\end{array}$ & $\begin{array}{l}\text { Variable } \\
\text { O\&M Cost } \\
\text { (2010 } \\
\text { \$/MWhe) }\end{array}$ & $\begin{array}{l}\text { Years to } \\
\text { Construct }\end{array}$ & $\begin{array}{c}\text { Capacity } \\
\text { Factor (from } \\
\text { EIA 2009 } \\
\text { Data) }\end{array}$ & $\begin{array}{l}\text { Fuel Price, } \\
\$ / M M B t u\end{array}$ & \$/Mwhe \\
\hline Single Unit Advanced PC & 650,000 & 8,800 & 3,167 & 35.97 & 4.25 & 3 & 0.85 & 2.27 & 109.40 \\
\hline Single Unit Advanced PC with CCS & 650,000 & 12,000 & 5,099 & 76.62 & 9.05 & 3 & 0.85 & 2.27 & 136.20 \\
\hline Conventional NGCC & 540,000 & 7,050 & 978 & 14.39 & 3.43 & 1 & 0.87 & 5.71 & 66.10 \\
\hline Advanced NGCC & 400,000 & 6,430 & 1,003 & 14.62 & 3.11 & 1 & 0.87 & 5.71 & 63.10 \\
\hline Advanced NGCC with CCS & 340,000 & 7,525 & 2,060 & 30.25 & 6.45 & 1 & 0.87 & 5.71 & 89.30 \\
\hline Conventional CT & 85,000 & 10,850 & 974 & 6.98 & 14.70 & 1 & 0.30 & 5.71 & 124.50 \\
\hline Advanced CT & 210,000 & 9,750 & 665 & 6.70 & 9.87 & 1 & 0.30 & 5.71 & 103.50 \\
\hline Dual Unit Nuclear & $2,236,000$ & 10,000 & 5,335 & 88.75 & 2.04 & 7 & 0.90 & 0.90 & 113.90 \\
\hline Biomass BFB & 50,000 & 13,500 & 3,860 & 100.50 & 5.00 & 2 & 0.83 & 2.74 & 112.50 \\
\hline Onshore Wind & 100,000 & & 2,438 & 28.07 & & 1 & 0.34 & & 97.00 \\
\hline Offshore Wind & 400,000 & & 5,975 & 53.33 & & 2 & 0.34 & & 243.20 \\
\hline Solar Thermal & 100,000 & & 4,692 & 64.00 & & 1 & 0.18 & & 311.80 \\
\hline Large Photovoltaic & 150,000 & & 4,755 & 16.70 & & 1 & 0.25 & & 210.70 \\
\hline Hydro-electric & 500,000 & & 3,076 & 13.44 & & 3 & 0.52 & & 86.40 \\
\hline
\end{tabular}

A 2,400 MWt HTGR plant using a Rankine steam turbine generator produces about $975 \mathrm{MWe}$. If the HTGR were assumed to account for $10 \%$ of the total nuclear power deployment on the grid in the time frame 2020 to 2050 , forty-six 2,400 MWt plants (184 reactor modules rated at $600 \mathrm{MWt}$ ) would be required. If the HTGR plants were replacing only natural gas fired plant, the reduction in $\mathrm{CO}_{2}$ emissions in 2050 would be $\sim 150$ million metric tons per annum and natural gas consumption would be reduced by 3.4 trillion cubic feet per annum. If the HTGR plants were substituted for coal plants the reduction in $\mathrm{CO}_{2}$ would be $\sim 300$ million metric tons per annum.

\subsubsection{Summary of Deploying HTGR Technology}

Table 10 summarizes the results of the assumed deployment of HTGR technology in the four sectors described above.

Table 10. Summary of results.

\begin{tabular}{|c|c|c|c|c|}
\hline Item & $\begin{array}{c}\text { Power } \\
\text { Requirement } \\
\text { (MWt) }\end{array}$ & $\begin{array}{l}\text { Number of } \\
600 \mathrm{MWt} \\
\text { Modules } \\
\end{array}$ & $\begin{array}{c}\mathrm{CO}_{2} \text { Emissions } \\
\text { Reductions } \\
\text { (million metric tons) } \\
\end{array}$ & $\begin{array}{l}\text { Natural Gas Usage } \\
\text { Reductions } \\
\text { (trillion cubic feet) }\end{array}$ \\
\hline $\begin{array}{l}\text { Co-generation and } \\
\text { process heat }\end{array}$ & 75,000 & 125 & 110 & 2.2 \\
\hline Hydrogen production & 36,000 & 60 & 15 & 0.44 \\
\hline Oil sands & 18,000 & 30 & 23 & 0.41 \\
\hline $\begin{array}{l}\text { Coal/biomass to fuel } \\
\text { and feedstock }\end{array}$ & 249,000 & 415 & 80 to 410 & N/A \\
\hline Electricity generation & 110,400 & 184 & $\begin{array}{l}\sim 150 \text { replacing } \mathrm{CCGT}^{*} \text { or } \\
\sim 300 \text { replacing coal plant }\end{array}$ & $\begin{array}{l}3.4 \text { (if replacing } 150 \\
\text { CCGT units) }\end{array}$ \\
\hline TOTALs & 488,400 & 814 & 378 to 858 & 6.45 \\
\hline
\end{tabular}


Full realization of this estimate in penetrating the targeted markets for the HTGR technology would result in:

- Deployment of 488,400 MWt of HTGR technology ( $\sim 800$ reactor modules rated at $600 \mathrm{MWt}$ )

- Providing steam, electricity, and high temperature gas to the process heat market; providing steam and hydrogen for bitumen recovery and upgrading from oil sands; producing hydrogen for the merchant market; and producing synthetic fuels and feedstock from coal and biomass

- Providing a significant fraction of non-greenhouse-emitting electricity generation on the national electrical grid

- Reducing the importation of $\sim 2.4$ million bpd of imported crude oil ( $\sim 25 \%$ of the imported oil in 2009); replacing the equivalent in crude-oil-based gasoline and diesel fuels with synthetic transportation fuels produced from coal

- Implementing a beneficial and efficient use of coal without generating greenhouse-gas emissions

- Reducing 6.5 trillion scf in natural gas consumption in the United States, per annum

- Reducing $\mathrm{CO}_{2}$ emissions by $\sim 400$ million metric tons per annum (reducing by $\sim 8 \%$ the total $\mathrm{CO}_{2}$ emissions in the United States). 


\section{SCHEDULE AND BENEFITS TO DEPLOYMENT OF HTGR TECHNOLOGY}

Based on the current NGNP Project schedule the first-of-a-kind HTGR module is targeted to begin operation in the 2023 time frame. This is anticipated to be the first module in a multi-module plant supplying energy to an industrial process. It is assumed that the subsequent deployment of HTGR technology to achieve the broad range of applications targeted by the NGNP Project would occur in the mid-2020 to 2050 range. The NGNP Project has evaluated the impact of this potential deployment of the HTGR technologies in combination with other initiatives of U.S. energy infrastructure transformation to address energy security, price volatility, natural resource management, and $\mathrm{CO}_{2}$ emission reductions. ${ }^{1}$ This referenced evaluation assumed a larger deployment of the HTGR technology than is described herein, concluding that in addition to effecting a reduction in the need to import crude oil, full deployment of the HTGR technology would reduce projected annual $\mathrm{CO}_{2}$ emissions in 2050 by $\sim 915$ million metric tons. This is $\sim 16 \%$ of the total reductions in $\mathrm{CO}_{2}$ emissions in 2050 that are required to meet the emission reduction objectives of the Administration and Congress. ${ }^{14}$

In summary, there are several benefits in pursuing all of the potential applications identified for use of the HTGR technology:

- Application of the HTGR in all of the potential industrial process applications preserves our limited natural resources. Many of these processes use significant quantities of natural gas (e.g., for steam production and generation of hydrogen). The use of the HTGR technology in place of natural gas preserves this nonrenewable natural resource for more beneficial purposes.

- Application of the HTGR supports improving the energy security of the United States by reducing the need to import crude oil and natural gas.

- The use of coal and biomass as feedstock for transportation fuel production with the HTGR as the source of process heat and cogeneration supports the beneficial use of one of the most abundant forms of energy in the United States. Coal and biomass can also be converted to feedstock for petrochemical processes, thereby reducing the usage of natural gas for this purpose and improving the security of this feedstock supply.

- Changes in the long-term operating costs for production of energy from an HTGR will be affected only by traditional inflationary factors affecting personnel wages, utilities, and commodities. They will not be subject to the volatility experienced in the prices of fossil fuels over the last decade as with natural gas.

Figure 16 shows the volatility of natural gas by plotting the historical and projected prices of natural gas since 1990 and projected to 2035 by DOE-EIA. ${ }^{15}$ Three projections from 2009, 2010, and 2011 of natural gas prices are shown on this figure. The large variation in price projections reflects the volatility of natural gas prices and the emergence of recovery of large shale gas reserves in the United States over the last several years. Figure 17 shows the projections by EIA for the increase in production of shale gas that is the underlying factor that led to the lower projected price of natural gas in EIA AEO 2011. There are many factors that can affect both the projections of shale gas production and pricing that add uncertainty to these projections, (e.g., high demand and pricing offshore that leads to increased export of natural gas and increased domestic pricing, energy parity with other carbon fuels such as oil, environmental concerns with shale gas fracking, government regulation of carbon emissions).

Although energy pricing from the HTGR supply will be affected by market conditions the inherent stability in its operating costs will support establishing longer term stability in energy pricing to improve confidence in the long term planning of the supplied industrial processes. This not only helps to insulate these processes from energy price volatility, but also from potential disruption of sources of fossil fuels. 


\section{Natural gas price projections are significantly lower than past years due to an expanded shale gas resource base}

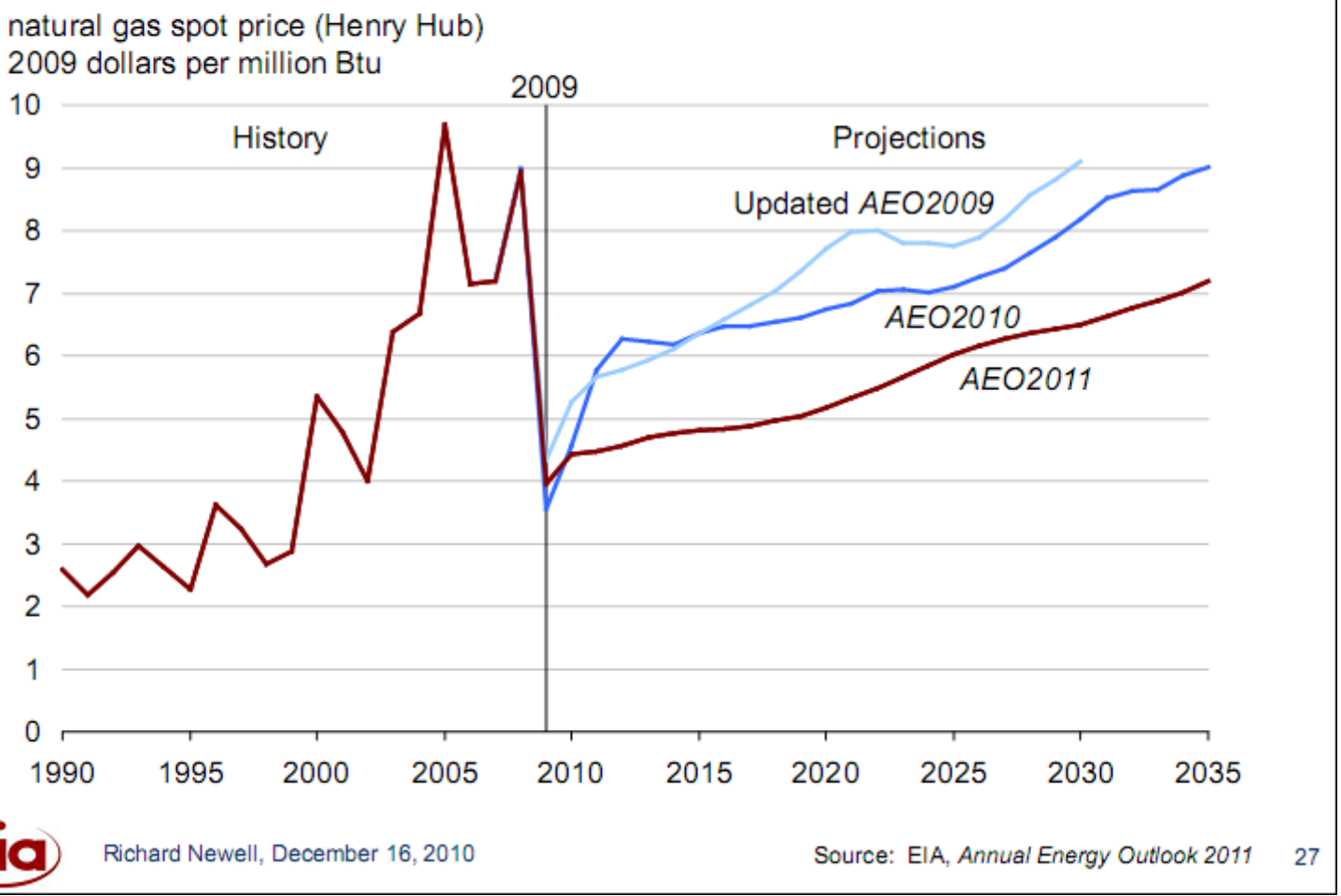

Figure 16. History and projections of utility user natural gas prices for 1970 to 2030.

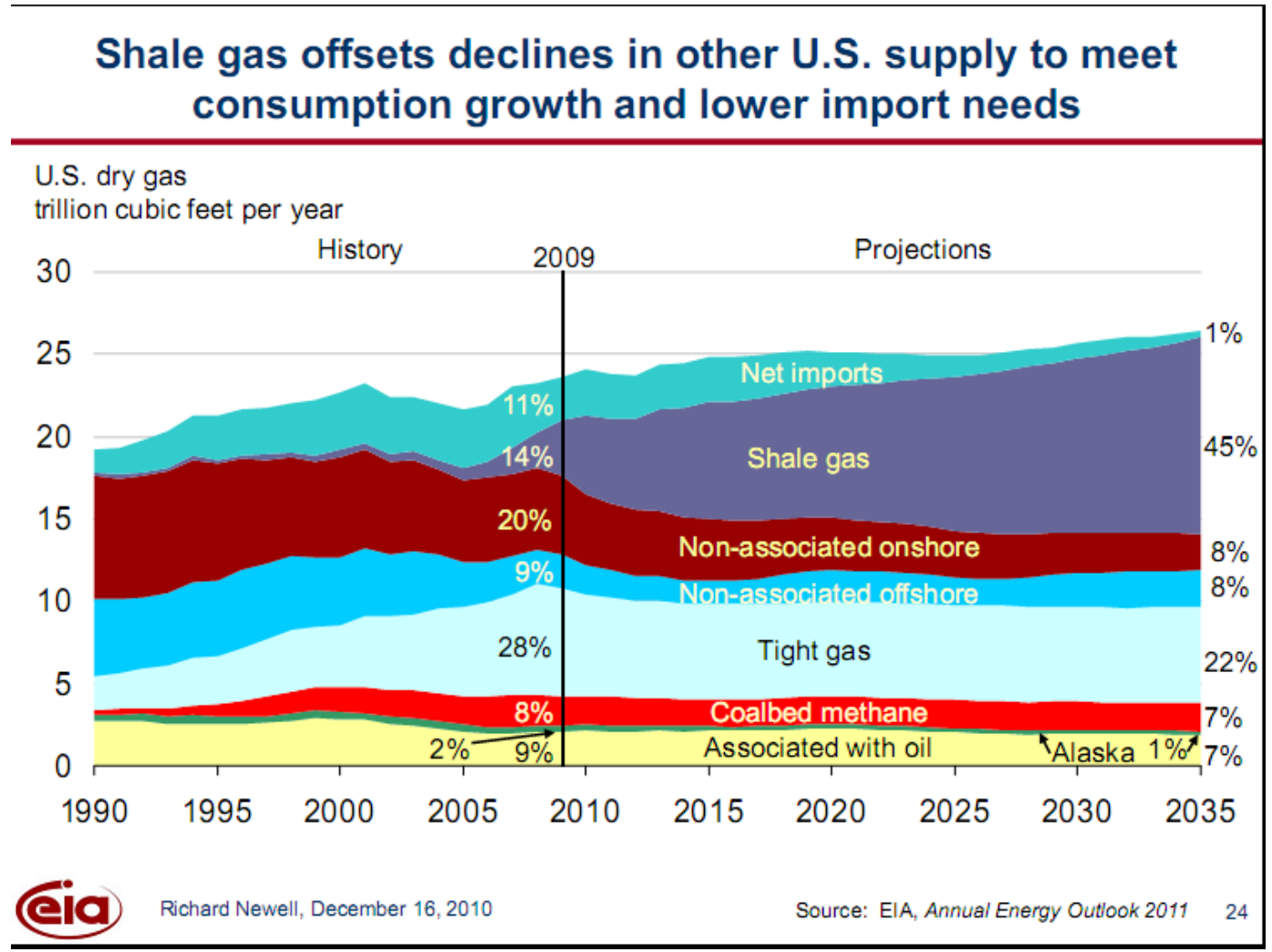

Figure 17. EIA Projections of the Sources of Natural Gas Production through 2035 
Use of the HTGR technology in these applications eliminates the significant amounts of greenhouse gas emissions released by traditional processes. A comparison of the $\mathrm{CO}_{2}$ emissions of conventional processes for coal-to-liquids production and traditional crude oil refining with that supported by the HTGR technology for the production of transportation fuels is shown above in Figure 15. As can be seen, the HTGR essentially eliminates $\mathrm{CO}_{2}$ emissions from the production phase (well to tank). This avoids cost pressures that may evolve from future governmental actions to curb carbon emissions. 


\section{TECHNICAL AND ECONOMIC EVALUATIONS OF HTGR TECHNOLOGY INTEGRATION WITH INDUSTRIAL PROCESSES}

The NGNP Project has performed technical and preliminary economic evaluations of integrating the HTGR technology with several conventional processes. ${ }^{16}$ These evaluations cover the specific processes within the applications discussed in the characterization and sizing of the potential HTGR markets above, as well as the others identified in the following:

- Co-generation applications supplying steam, electricity, and hot gas as well as for electricity only production.

- Bitumen recovery and upgrading in the Canadian oil sands

- Coal and natural gas derivatives production including ammonia from coal and natural gas, converting natural gas and coal to liquid fuels such as gasoline and diesel, and converting coal to substitute natural gas

- Petrochemicals production such as supplying steam, electricity, and hot gas to support conversion of natural gas to chemical products

- Production of hydrogen such as substituting HTGR hot gas for combustion of natural gas in the SMR process, eliminating natural gas burning and feedstock through the use of HTSE for the production of hydrogen and oxygen

- Production of ammonia and ammonia derivatives (e.g., Urea, fertilizers) using HTGR steam and hot gas as a substitute for burning natural gas or to supply pure hydrogen and nitrogen directly to the ammonia synthesis reactor using the HTGR and HTSE

- Shale oil recovery applying the ex-situ and in-situ processes

- Coke/steel production

- Sensitivity of the technical viability of using HTGR heat in the Steam Methane Reforming process as a function of the HTGR reactor outlet temperature Biomass conversion to gas or liquids

- Methane hydrates.

The medium category processes identified in Section 2 include those that require higher temperatures than the HTGR technology can currently supply. As noted for cement production, however, it is possible that revisions to the process could reduce the temperature requirements to be compatible with HTGR temperatures and improve the efficiency of the processes. These will be explored in the future as the next set of priorities for the project or as specific potential end users in these areas are consulted. 


\section{BUSINESS CONSIDERATIONS IN APPLYING THE HTGR TECHNOLOGY TO INDUSTRIAL APPLICATIONS}

\subsection{The Business Model}

The integration of the HTGR technology with industrial processes involves the transport of energy from the modular reactors to the processes in the form of steam, electricity, high temperature gas, or other heat transport fluid (e.g., molten salt), and could include hydrogen and oxygen, depending on the process needs and the plant configuration. This is similar to current co-generation arrangements in many industrial processes wherein a central plant co-located with the process will provide energy to the process. Many of the current co-generation plants use natural gas or waste gas to generate the energy. These cogeneration plants may be owned and operated by the owner/operator of the process or by a separate entity. In the latter case, the energy is delivered under contract "over the fence." For a nuclear co-generation plant, it is judged to be unlikely that a traditional owner/operator of an industrial plant (e.g., petrochemical, refining, ammonia/fertilizer) would undertake operation of the nuclear plant, because of their lack of experience with its licensing and operating requirements. Accordingly, an entity with nuclear plant operating experience, separate from the industrial plant owner/operator, could operate the nuclear plant. The owner of the nuclear plant would enter into a contract with the industrial plant for supply of energy in the required forms "over the fence" to the processes.

Figure 18 shows a possible business model. It illustrates the likelihood that there would be several "owners" (i.e., equity holders) of the HTGR plant. The principal owner of the plant may or may not be the operator. The HTGR could also be supplying energy to more than one industrial facility and have multiple energy supply agreements. It is also assumed that the plant would be selling excess generated electricity to the grid. As noted in the prior discussion of the co-generation application selling excess electricity to the grid is a common arrangement for these plants.

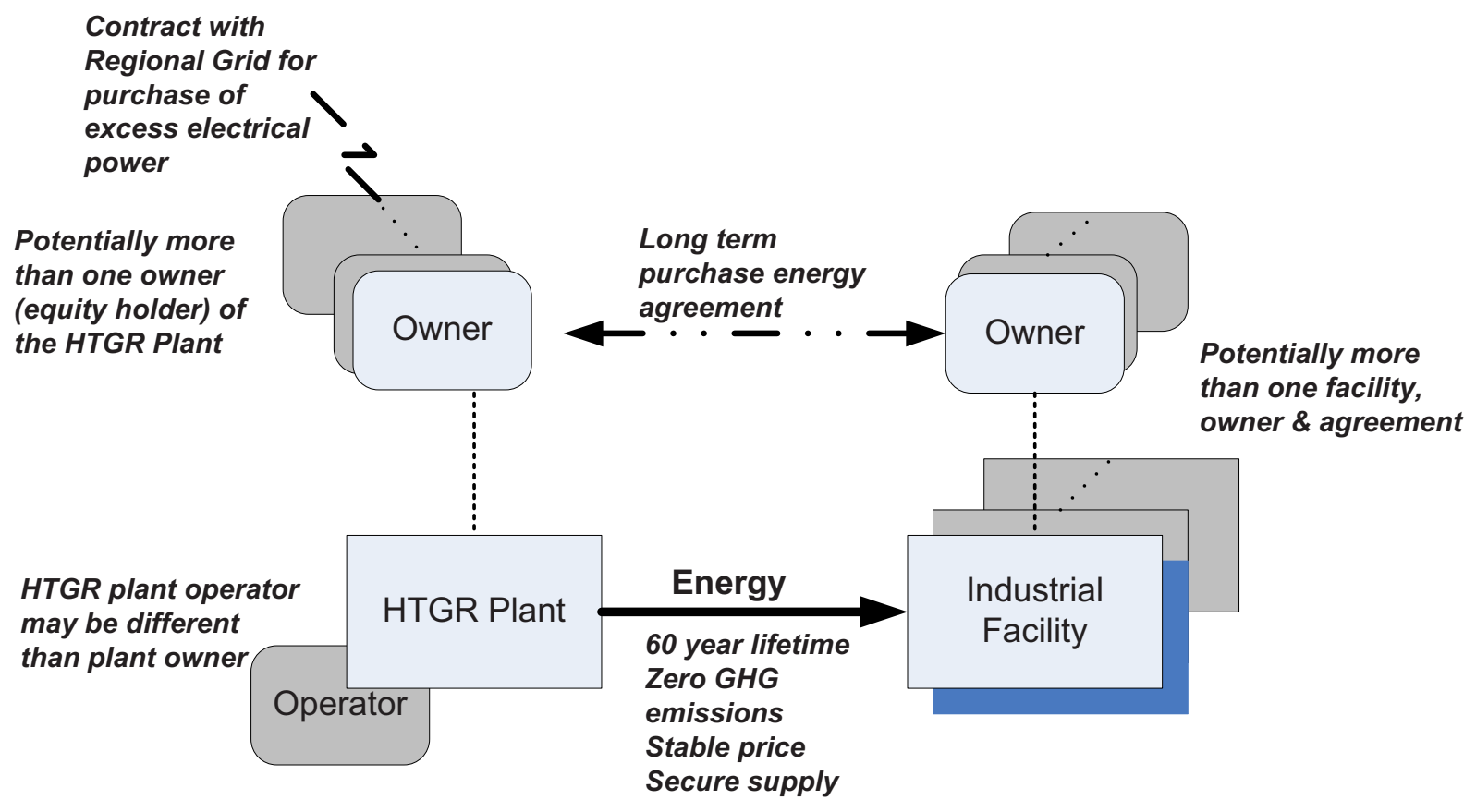

\section{Figure 18. Business Model}

The "business model" used in the economic analyses performed for each of the potential markets varies depending on the market. For the cogeneration market the prices for the steam, electricity and hot gas supplied to the industrial facility are calculated. A prospective industrial plant would evaluate whether those prices are judged to be competitive with traditional fossil sources of energy over the long term (60 
years or more). In this case the HTGR plant is supplying energy "over the fence" and is, therefore, not tightly coupled with the process. In this model there is a distinct division between the HTGR plant and the industrial facility.

In other markets, (e.g., hydrogen generation) the HTGR can be tightly coupled with the process and the projected price of the product, (e.g. hydrogen) is calculated and compared with projected prices using conventional processes. This can blur the line between the owners of the HTGR plant and the owners of the industrial plant. In these cases the costs for construction and operation of both the HTGR plant and the industrial plant are combined in the economic analyses.

\subsection{HTGR Plant Economics versus CCGT Economics}

There are fundamental differences in the economics of a nuclear plant as the energy supplier to a process compared with that of a natural gas fired combined cycle gas turbine (CCGT) plant. The latter is a common co-generation application in the industrial sector. As shown in Figure 19, in a natural gas fired plant the fuel costs account for the majority of the annual operating costs. These plants can, therefore, be cycled without major economic penalty. Much of the combined cycle plant equipment is also more "portable" than nuclear plant equipment and could be re-located if the original energy market becomes no longer available.

As shown in Figure 19, the nuclear plant costs are comparatively capital recovery intensive with low operating costs. The nuclear plant will also have a longer lifetime (e.g., 60 years) than the typical fossil based CCGT plant, (e.g., 20 to 30 years). The recovery of capital accounts for approximately $70 \%$ of the annual costs of operating a new nuclear plant compared to about $30 \%$ for a CCGT plant. Since the capital recovery is a fixed annual cost the nuclear plant must run at a high capacity factor to be economic compared to the CCGT plant. The nuclear plant also requires a long term stable energy market. This puts a premium on developing and sustaining an energy demand profile for the nuclear plant that maximizes its long term availability and capacity factor.
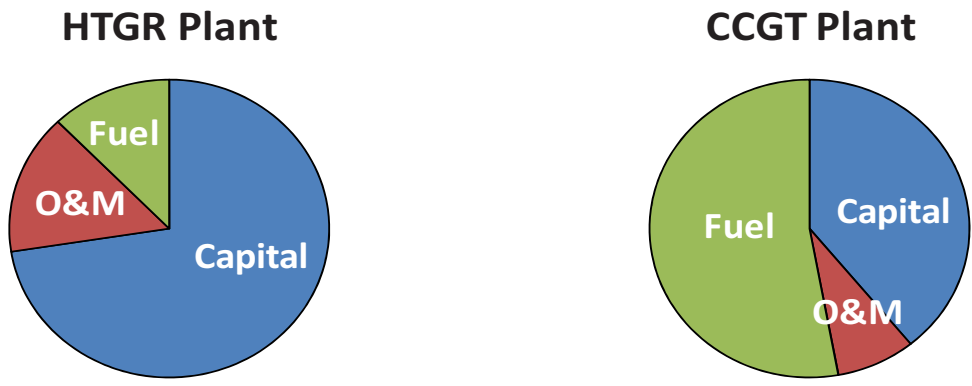

Figure 19. Comparison of the operating cost elements of an HTGR with a CCGT plant. (Developed in Excel file, "CCGT (7FA) steam \& elec 5-24-11")

\subsection{Example of Possible HTGR and Industrial Plant Business Cases}

When the HTGR plant is supplying energy "over the fence," (i.e., is a separate entity from the industrial facility) there are two business cases that must be compatible to make integrating the HTGR technology with the industrial application economically viable: (1) that of the HTGR plant owner who will set a price for the delivered energy that fulfills his project economic criteria (e.g., return on the equity investment), and (2) that of the industrial plant owner who must be able to meet his economic criteria at that price of energy (e.g., setting a price for his product that is competitive and provides the requisite return and provides a hedge on feedstock real escalation and/or volatility). Evaluations of specific applications of this nature have shown that it is important to separate these two business cases because there are substantive differences in the economic factors such as debt ratio, period of financing, interest rates, and required return on investment typically applied by these two entities. 
There are other factors that need to be considered in assessing the economic viability of the application.

- The HTGR plant may need to be oversized from that size required to meet the basic energy needs of the industrial process so that availability requirements for supply of the energy can be assured. Close to $100 \%$ availability requirements are typical for much of the energy supply for an industrial process. The HTGR plant owner could be expected, therefore, to assess whether there are other potential markets to which any excess energy can be offloaded. The local electrical grid is a potential taker of any excess energy. The viability of this alternative is driven by the economics of the regional electricity generation market.

- The nuclear plant owner will evaluate whether there are other industrial plants in the area or needs of the regional grid that would permit deploying an even larger plant. There are economies of scale that can accrue from siting a larger rated plant.

- The HTGR plant owner will evaluate both the regional electrical grid and other industrial plants as potential long-term alternatives for delivery of the energy if, over the longer term, the primary industrial plant is shuttered or production curtailed because of evolving economic conditions or other factors.

In a back-fit project, the owner of the industrial plant will need to assess how much, if any, of the original energy production equipment to retain in operation as backup to the HTGR plant. This may be a phased activity - less backup equipment is retained as more confidence in the reliability of the HTGR plant is developed.

For either a back-fit or Greenfield application, the owner of the industrial plant may include other factors than the price of the delivered energy in evaluating the viability of the HTGR plant as a long term energy supply. Some of these factors could include:

- The HTGR plant provides a long term (60 years or more) stable cost of energy; separating the costs of production from the significant volatility of fossil fuel prices experienced over the last decades, thus adding more certainty to future planning.

- The HTGR plant integrated with carbon conversion processes provides a long term secure and dedicated source of energy carriers and feedstock; eliminating concerns with disruption of energy carrier and feedstock supply from the traditional fossil sources.

- The HTGR plant is a non-greenhouse gas emitting source of energy, eliminating concerns with the effects of potential government policies that result in a cost for carbon emissions contributing to the volatility of the price of fossil energy.

- Fossil energy sources currently used for energy production (e.g., oil, natural gas, coal) may have more financial benefit as feedstock to the process. For example, the waste gases that were formerly burned in the power houses may be convertible to revenue producing products. When waste gas is used to provide energy to an industrial process, the differential between the cost of imported sources of the fossil fuel (e.g., natural gas) and the market price of the product that could be produced from the waste gas and the cost of processing the waste gas are key factors in the economics of such a conversion. In the conventional processes reviewed by the Project, these factors lead to the decision to burn the waste gas rather than process it. The factors affecting the economics of such conversion will be different with an HTGR energy source, and may be more favorable.

- For future Greenfield applications, improved efficiencies and economics are expected in the processes by reengineering them for integration with the nuclear plant.

- The schedule for initial deployment of an HTGR plant is expected to be in the mid- to late-2020s, assuming a focused and stable NGNP Project is established. While there is high uncertainty in predicting the sources, forms, and costs of energy that far into the future, the national commitment to secure the option as a hedge for such uncertainties needs to be established now. 


\section{EXAMPLES OF APPLICATION OF THE HTGR TO INDUSTRIAL PROCESSES}

The following sections discuss the results of NGNP Project evaluations of the application of the HTGR technology to supplying all or some of the energy needs of industrial processes. The firstco-generation - is judged by the Project and the HTGR suppliers to have low technical risk, a large potential market, significant energy price stability, energy security and environmental benefits, and economic viability. This judgment is based on the nature of the energy needs of this application; principally steam, electricity, and hot gas with modest temperature requirements, (e.g., 700 to $850^{\circ} \mathrm{C}$ ).

The latter two processes (conversion of coal to transportation fuels and ammonia and ammonia derivative production), which are discussed below, represent applications of the HTGR technology that address principally energy security by providing alternatives to imported crude oil and natural gas as feedstocks. These are more developmental than co-generation, relying, in some cases, on the development of the HTSE process for hydrogen production and higher HTGR operating temperatures to optimize the performance of that process. The economic evaluations of these two applications are, therefore, more uncertain. In any event, they are judged to be applications that require continued development to ensure that the benefits of HTGR technology in securing our energy sources, stabilizing our energy costs, preserving our natural resources, and reducing $\mathrm{CO}_{2}$ emissions are fully realized. The NGNP Project has received support for this continued development in discussions with major companies involved in these applications.

The economic evaluations discussed below use engineering, procurement and construction (EPC) cost estimates and operating cost estimates for a mature HTGR plant that have been developed by the NGNP Project. ${ }^{17}$ These cost estimates were developed by review of prior HTGR plant design work, (e.g., General Atomics designs of the MHTGR, NPR and GT-MHR, NGNP Project FY07 Pre-conceptual design work), special studies conducted for the NGNP Project by HTGR suppliers, current costs for common power plant components, (e.g., circulators, steam turbine generators, pumps) and bottoms up estimates of major components, (e.g., vessels). The cost estimates vary depending on the rating of each HTGR module, the reactor outlet temperature of the reactor, the rating of the multi-module plant and the plant configuration, (e.g., includes steam generators and/or intermediate heat exchangers, type and number of power conversion systems). Correlations were developed from the basic data to facilitate developing a cost estimate for a specific plant design considering module rating, plant rating, reactor outlet temperature and plant configuration. These cost estimates and correlations also consider three possible states for plant deployment; these are: as a first-of-a-kind demonstration plant, during the "learning curve" transition from the costs for a demonstration first-of-a-kind plant to an Nth-of-a-kind plant and as an Nth-of-a-kind plant). All of the analyses discussed below were performed for an Nth-of-akind plant status.

It should be noted that because the Project is still in the preconceptual design phase, there is large uncertainty in these costs. The Project is progressing into the conceptual design phase wherein more certain estimates of capital costs for the mature plant will be developed. The economics will be updated, as necessary, as the cost estimates become more certain.

\subsection{Co-generation}

This application involves the supply of energy to an industrial process typically in the form of steam, electricity, and/or hot gas from a power plant located either outside the industrial facility or embedded in the facility. The power plant may be owned and operated by an entity separate from the owner/operator of the industrial facility or be a part of the facility itself. A large number of these power plants in the United States are fired using natural gas or coal and waste gas from the industrial processes. These plants typically include some combination of steam boilers, steam turbine generators, and natural gas combined cycle (NGCC) plants. In a back fit application, the HTGR would replace or augment the installed equipment. In a Greenfield application, the HTGR would be the principal energy supply. As noted 
previously the schedule for commercial deployment of the HTGR plant is currently projected for the mid2020 s. By this time it is anticipated that there will be some governmental action on control of carbon emissions. Accordingly, whether the deployment of the HTGR is in a Brownfield or Greenfield application the most likely alternative energy supply that the HTGR would be compared with would be an advanced NGCC (higher efficiency than current models) with carbon capture and sequestration (CCS). The energy costs for the HTGR in a co-generation application are compared below with those of an Advanced NGCC w/CCS.

As noted in previous sections, it is likely that the HTGR plant would not be operated by the owner of the industrial plant, but rather by an entity with nuclear plant operating experience such as a current nuclear power plant owner/operator. The NGNP Project and the HTGR suppliers have worked with several owner/operators of industrial plants and with an owner/operator of nuclear electrical power plants to develop business cases for this co-generation application.

Figure 20 shows a comparison of the prices of electricity and steam from a new HTGR plant with that of a new advanced natural gas fired combined cycle gas turbine plant with carbon capture and sequestration (ADV NGCCW/CCS) as a function of the price of natural gas. Also shown on this Figure are historical electricity prices as a function of the price of natural gas. The HTGR plant is sized at $\sim 2400$ $\mathrm{MWt}$ - the rating required to supply a modest sized industrial plant with steam and electricity. It is compared with an Advanced NGCC w/CCS plant using EIA data on projected costs of generating electricity with several different technologies. ${ }^{12}$ The historical data for the price of electricity and steam as a function of natural gas price was provided by General Atomics as part of preparing a conceptual design report of a prismatic reactor co-generation plant. ${ }^{5}$ These comparisons are made for varying costs of natural gas in \$/MMBtu. This variation with natural gas price is shown because, as noted previously, the fuel costs dominate the costs of operating a natural gas fired plant. Two curves are shown for the HTGR illustrating the change in the costs when varying the internal rate of return on equity from 10 to $15 \%$

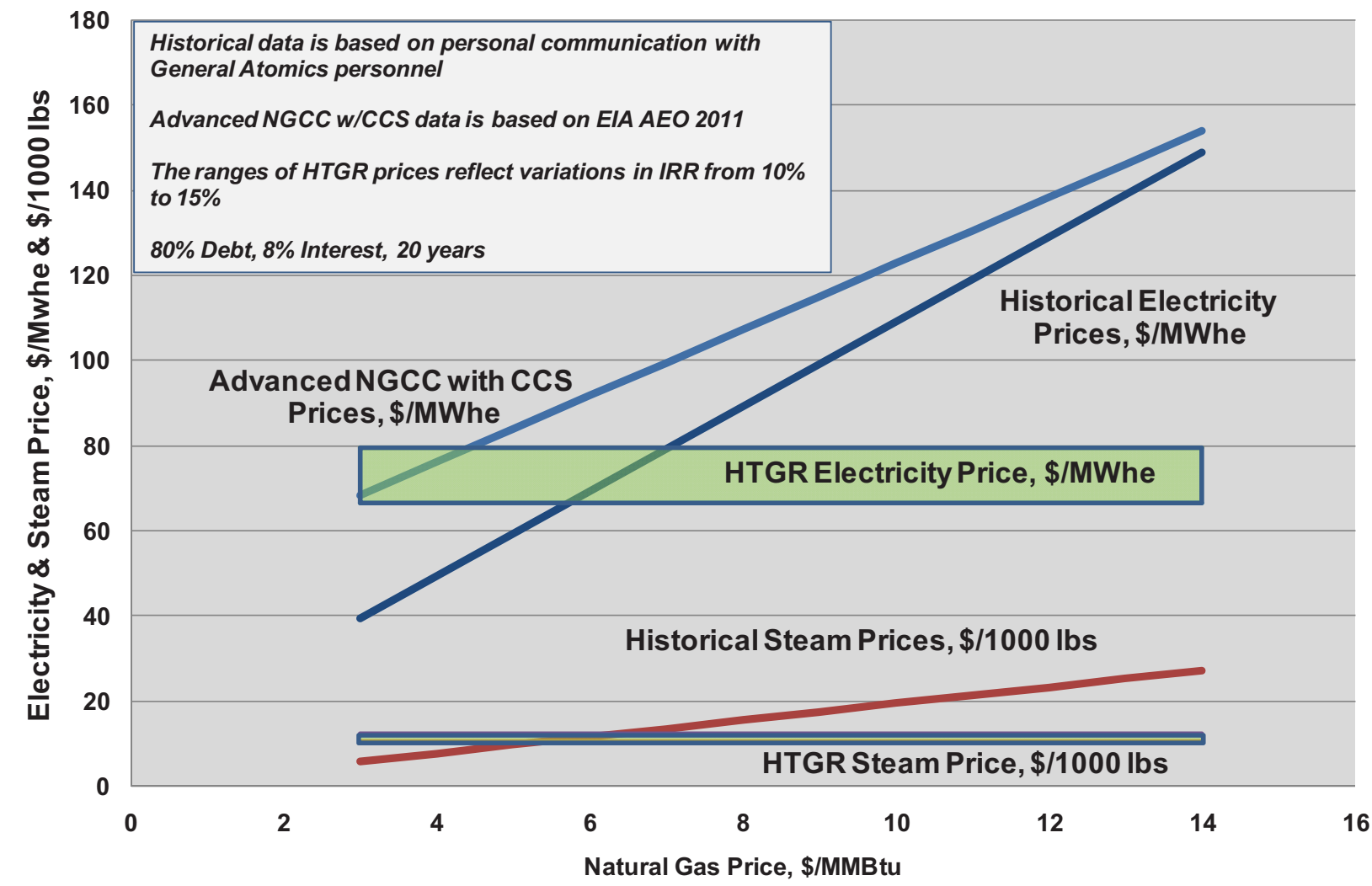

Figure 20. Comparing the price of electricity and steam for HTGR and NGCC plants (2009\$). (Developed in Excel file, "Baseline Co-gen Plant - 4-600 MWt_8-04-11") 
As shown in Figure 20 the price for the HTGR plant electricity and steam is equivalent to that of the Advanced NGCC w/CCS plant at natural gas prices in the range $\$ 3$ to $\$ 7 / \mathrm{MMBtu}$, depending on whether the comparison is made with historical prices or Advanced NGCC w/CCS prices and the IRR used for the HTGR plant. As shown in Figure 16, over the last 5 years, natural gas prices have ranged from a low of $\sim \$ 4 / \mathrm{MMBtu}$ to a high of $\sim \$ 13 / \mathrm{MMBtu}$ with high volatility. As also shown in Figure 16, the EIA projects a natural gas price in the \$7/MMBtu (2009\$) range in the time frame for deployment of HTGR plants, (i.e., mid-2020s and in the competitive range for the HTGR).

The HTGR will also reduce the use of natural gas burning for this purpose, thereby preserving this limited natural resource for more beneficial uses. The HTGR also eliminates the $\mathrm{CO}_{2}$ emissions that result from the burning of natural gas. Based on the EIA data, a base loaded (87\% capacity factor) $340 \mathrm{MWe}$ NGCCw/CCS plant would burn $\sim 20$ billion cubic feet of natural gas ( 1000 million lb) and emit $\sim 1,040,000$ metric tons of $\mathrm{CO}_{2}$ per year. Two of these NGCCw/CCS plants plus augmenting steam generators (also fired on natural gas or waste gas) would be required to meet the steam and electricity supply of the HTGR plant. The steam generators would also contribute to the emissions of $\mathrm{CO}_{2}$ and, when fired on natural gas, the consumption of natural gas.

\subsection{Conversion of Coal to Gasoline}

One of the processes evaluated by the NGNP Project in the HTGR Integration with Industrial Process Task $^{11}$ is the conversion of coal to gasoline using the methanol to gasoline (MTG) process. Liquid petroleum gas (LPG) is also produced in this process. In each of these evaluations of the potential for integration of the HTGR in the process, the conventional process is first modeled to determine where the HTGR could be used and to define the specific requirements for the HTGR application (e.g., heat input, electricity generation, hydrogen production). The conventional MTG process modeled for this evaluation is shown schematically in Figure 21.

Figure 22 shows the process with an HTGR energy source. The proposed process includes the same unit operations as the conventional coal-to-MTG process with the following exceptions: the cryogenic air separation unit and water gas shift reactors (a part of the gasification and syngas conditioning block) are replaced by high temperature steam electrolysis (HTSE) to provide oxygen and hydrogen for the process.

Figure 23 summarizes the results of the evaluation. In both cases $\sim 67,000$ bpd of gasoline and LPG are produced. As shown in this figure, the use of the HTGR energy source to supply heat and hydrogen reduces $\mathrm{CO}_{2}$ emissions from the conventional process by a net amount of 100 to 31,000 tons per day (0.04 to 10 million tons per year) depending on the amount of $\mathrm{CO}_{2}$ that can be captured in the conventional process.

Figure 24 summarizes the economic evaluation of this HTGR application. This figure shows the production price of gasoline for the conventional and HTGR integrated processes required to meet the economic criteria summarized on the figure as a function of the cost of $\mathrm{CO}_{2}$ emissions. As shown, the HTGR plant is competitive with the conventional process for costs of $\mathrm{CO}_{2}$ emissions in the $\$ 75 /$ ton range. The historical range in the price of gasoline in 2008 is also shown on this figure for information. Use of the coal-to-MTG process for production of gasoline using either the conventional or HTGR integration approach falls within the upper end of this range.

Figure 25 shows the gasoline pricing for the conventional and HTGR integrated process and for crude oil refining as a function of crude oil price in $\$ / \mathrm{bbl}$. The price of crude oil has varied considerably over the last decade ( $\sim 25 / \mathrm{bbl}$ in January $2000, \sim \$ 130 / \mathrm{bbl}$ in July 2008$)$. As shown, the conventional coal to MTG process is competitive with crude oil refining at crude oil prices in the range of $\$ 80 / \mathrm{bbl}$ (note the price range of crude oil at the time of this writing was in the range of $\sim \$ 100 / \mathrm{bbl}$ ) with no cost associated with $\mathrm{CO}_{2}$ emissions. At a cost of $\$ 50 /$ metric ton of $\mathrm{CO}_{2}$ emissions, the price of crude oil would have to be in the $\$ 110 / \mathrm{bbl}$ range for the conventional coal to MTG process to be competitive with crude oil refining. Similarly, the HTGR integrated process would be competitive with crude oil refining in the $\$ 125 / \mathrm{bbl}$ range. 


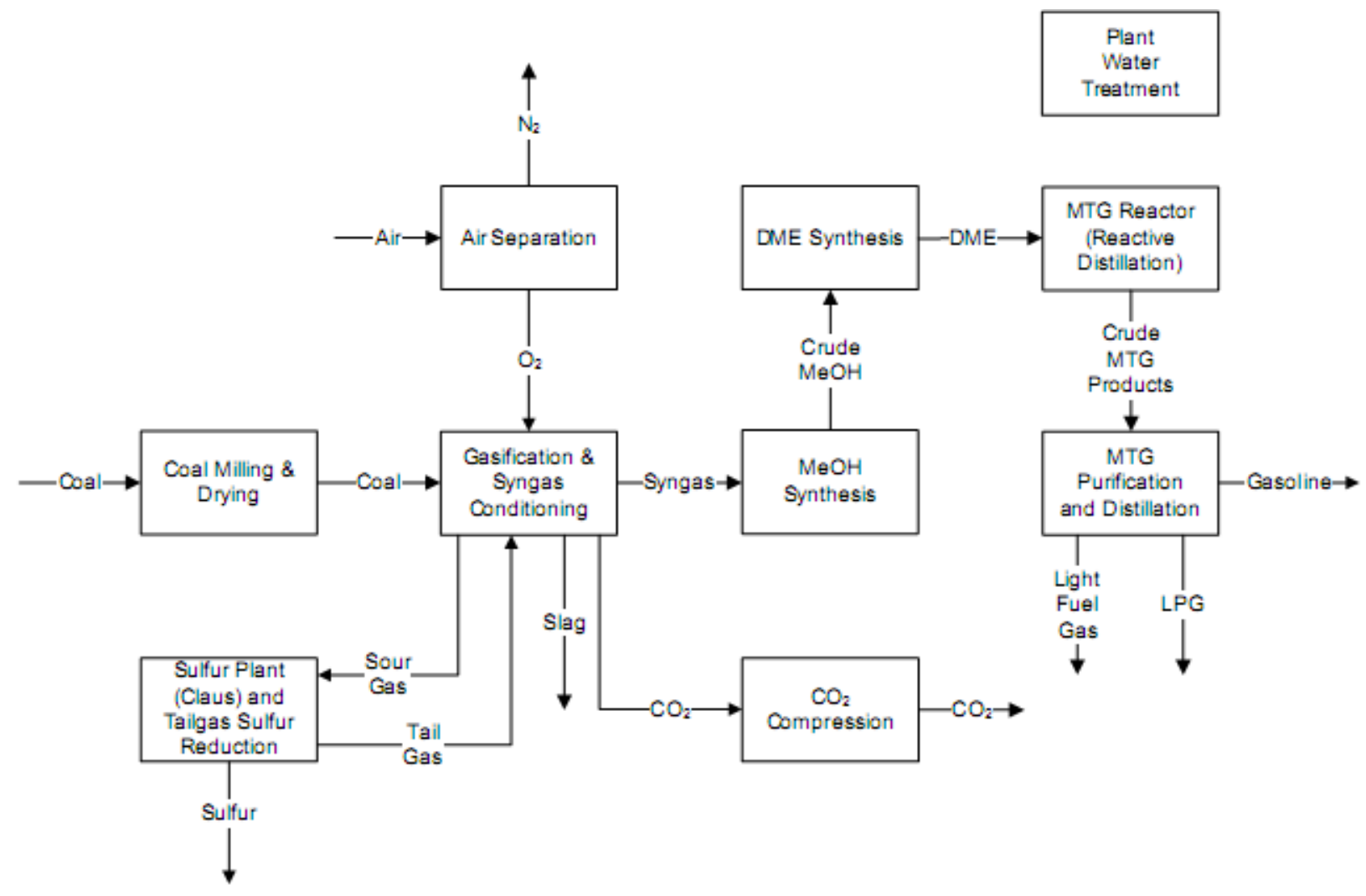

Figure 21. Block diagram of conventional coal to MTG process.

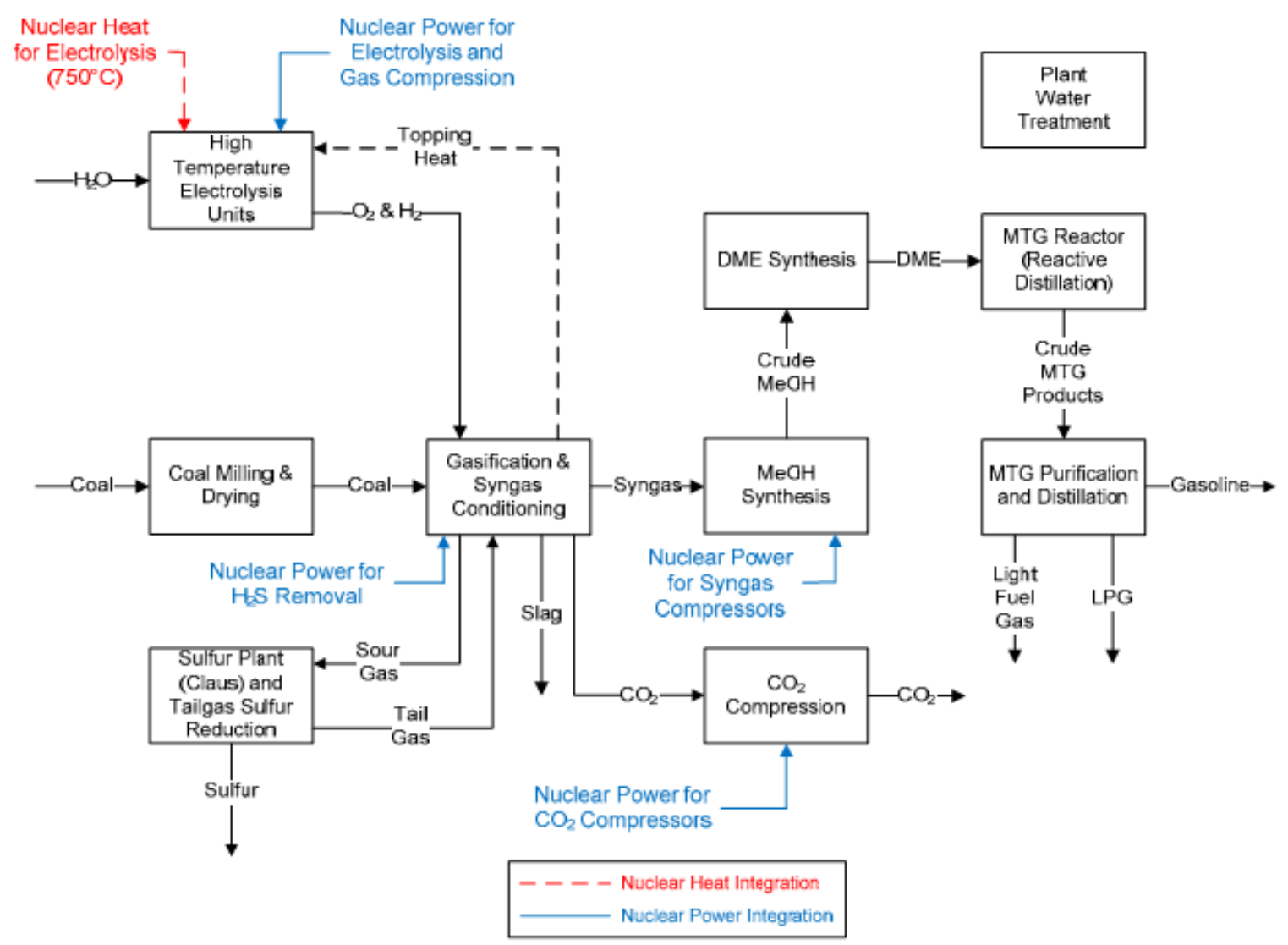

Figure 22. Block diagram of the HTGR integrated coal to MTG process. 

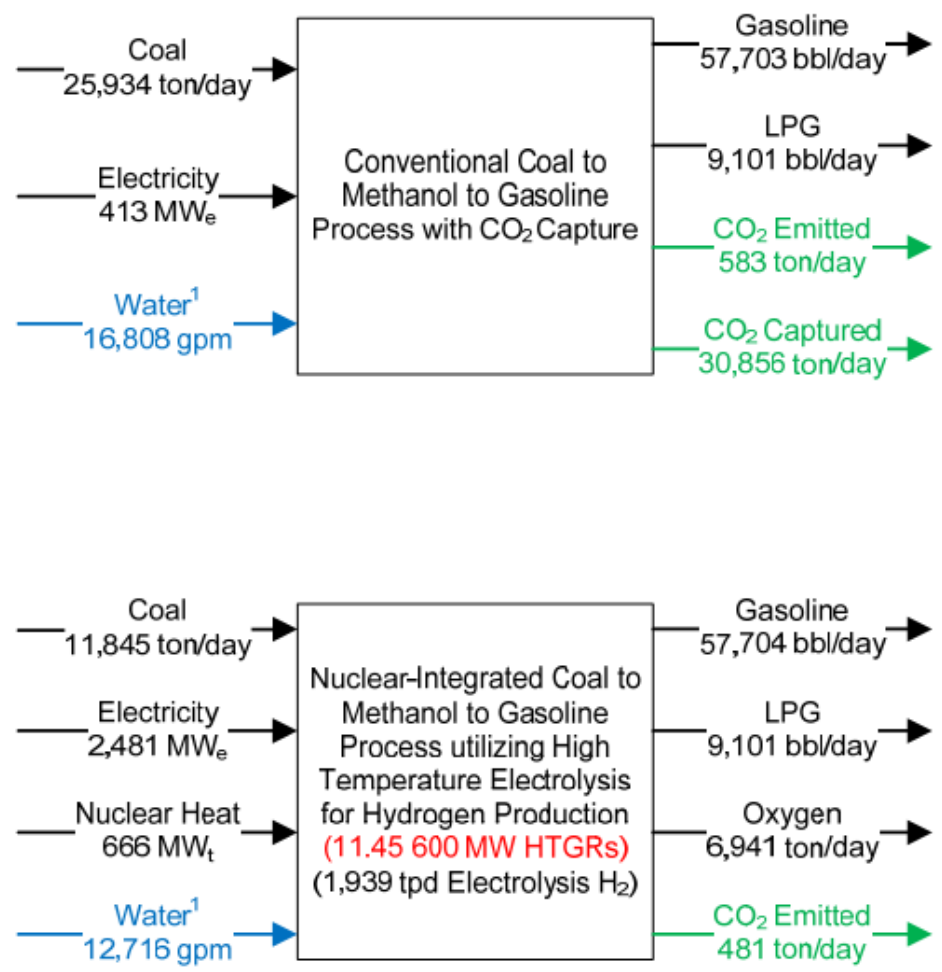

Figure 23. Conventional coal-to-MTG process compared with HTGR integrated coal-to-MTG process.

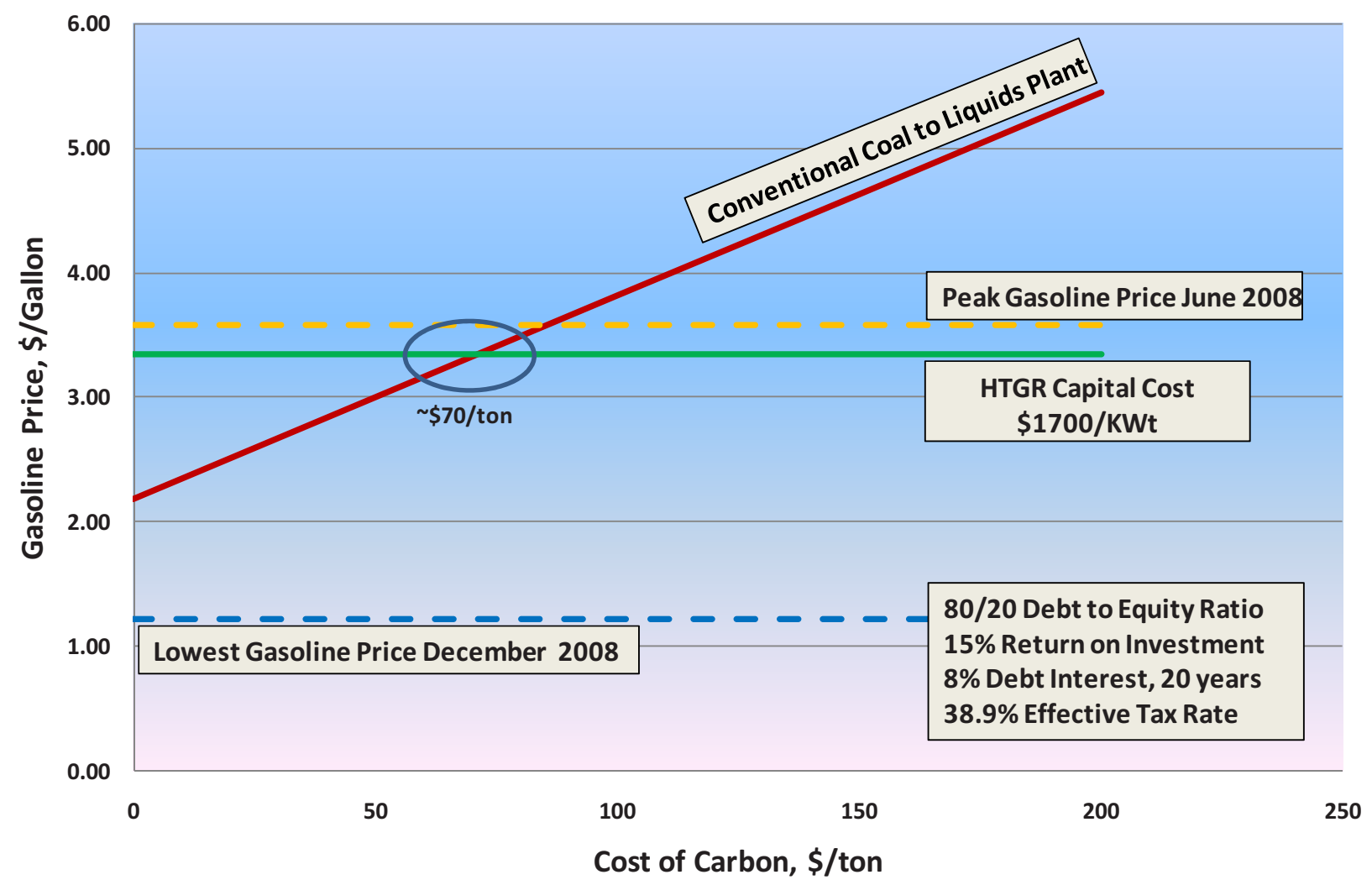

Figure 24. Results of the economic evaluation of conventional and HTGR integrated coal-to-MTG plants. (Gasoline price: well to tank; Peak and Low \$/gal between 2000 and 2009, developed in Excel file, "Backup Calcs on Industrial Sector Emissions \& Energy Consumption and CTL Plant") 


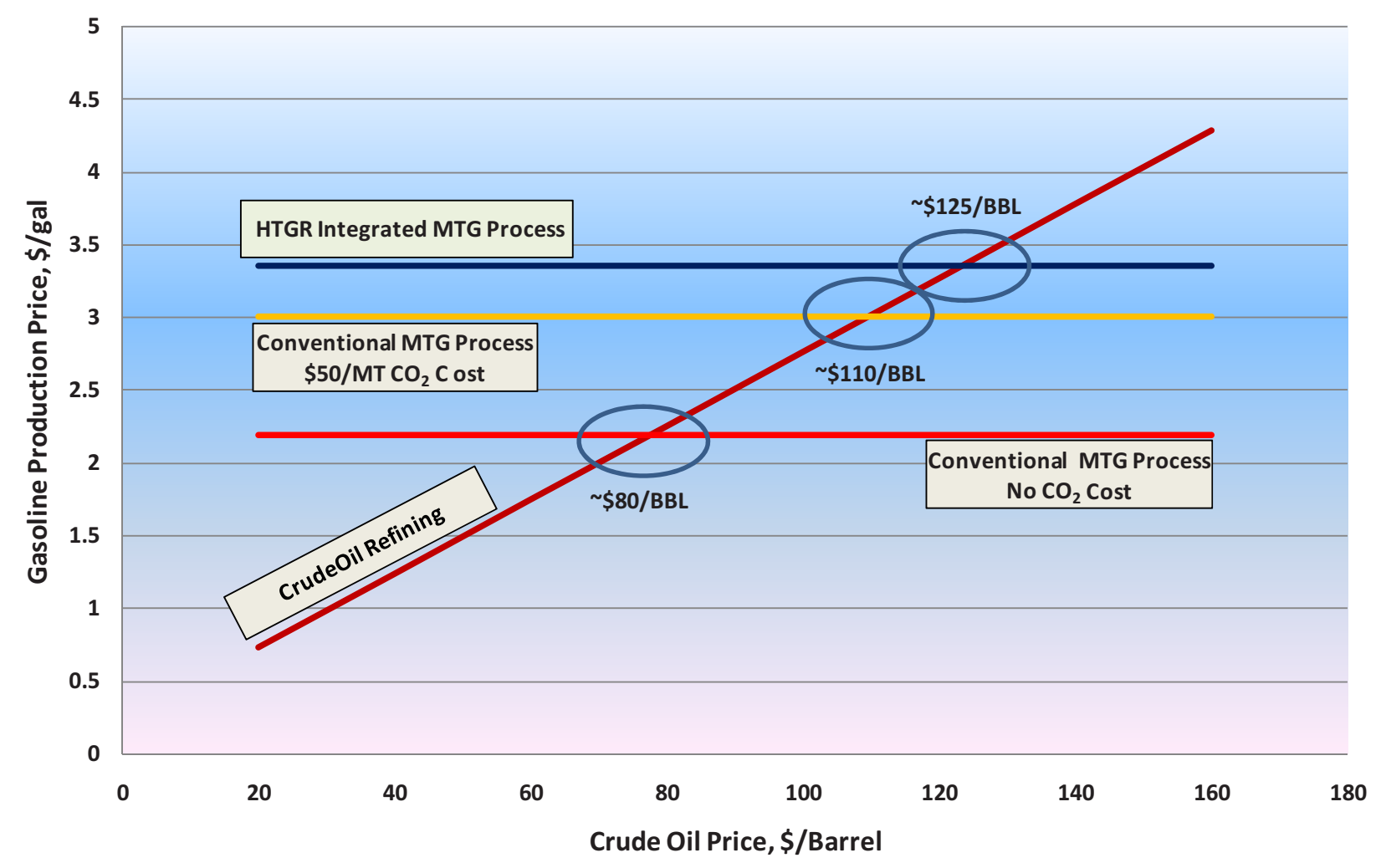

Figure 25. Comparison of the production price of gasoline for crude oil refining, conventional coal to MTG and HTGR integrated coal to MTG processes. (Developed in Excel file, "Backup Calcs on Industrial Sector Emissions \& Energy Consumption and CTL Plant")

These results indicate that the application of the HTGR technology to coal-to-MTG production of gasoline is marginally economic for the reference financial and economic factors, even when compared with the conventional process when subjected to additional costs for $\mathrm{CO}_{2}$ emissions. The large capital cost investment required for the HTGR plant in production of hydrogen, oxygen, and process heat provides a disadvantage when compared with the relative low capital cost for the conventional plant. Additionally, the supply of hydrogen, oxygen and process heat in this case does not significantly reduce the complexity of the MTG plant and eliminate significant components and systems. Therefore, the additional costs of the HTGR plant add to rather than substitute for the majority of the conventional plant costs. The viability of this alternative would also be affected by governmental actions that prescribe the pursuit of substitute transportation fuels.

As the HTGR technology develops the technical and economic viability of the technology for this application will be revisited and continued to be evaluated with potential end users.

\subsection{Integration of the HTGR Technology in an Ammonia Production Plant}

The NGNP Project has developed detailed process flow sheets for integration of HTGR process heat into processes for production of ammonia and ammonia derivative products such as urea used in the production of fertilizer. These flow sheets were validated by ammonia equipment and system designers, meetings with producers of ammonia, and a tour of an operating plant. Scoping evaluations were also initiated with the objective of comparing the economics of the HTGR integrated plant with the economics of a conventional plant. These analyses were performed for a typical plant producing 2,500 tons per day of ammonia. 
In discussions on applying HTGR technology as a source of process heat and reviews of evaluations of integrated processes, a major producer of ammonia and ammonia derivatives recommended that the evaluations focus on just the production of ammonia. The information from that evaluation will facilitate the industry's evaluation of the viability of the output of that process for use of the ammonia as feedstock for further processing. To that end, two different applications of an HTGR integrated plant for the production of ammonia were evaluated. The first used HTGR process heat to offset the burning of natural gas in the primary reforming stages of a conventional process. A simplified flow sheet for this process is shown in Figure 26.

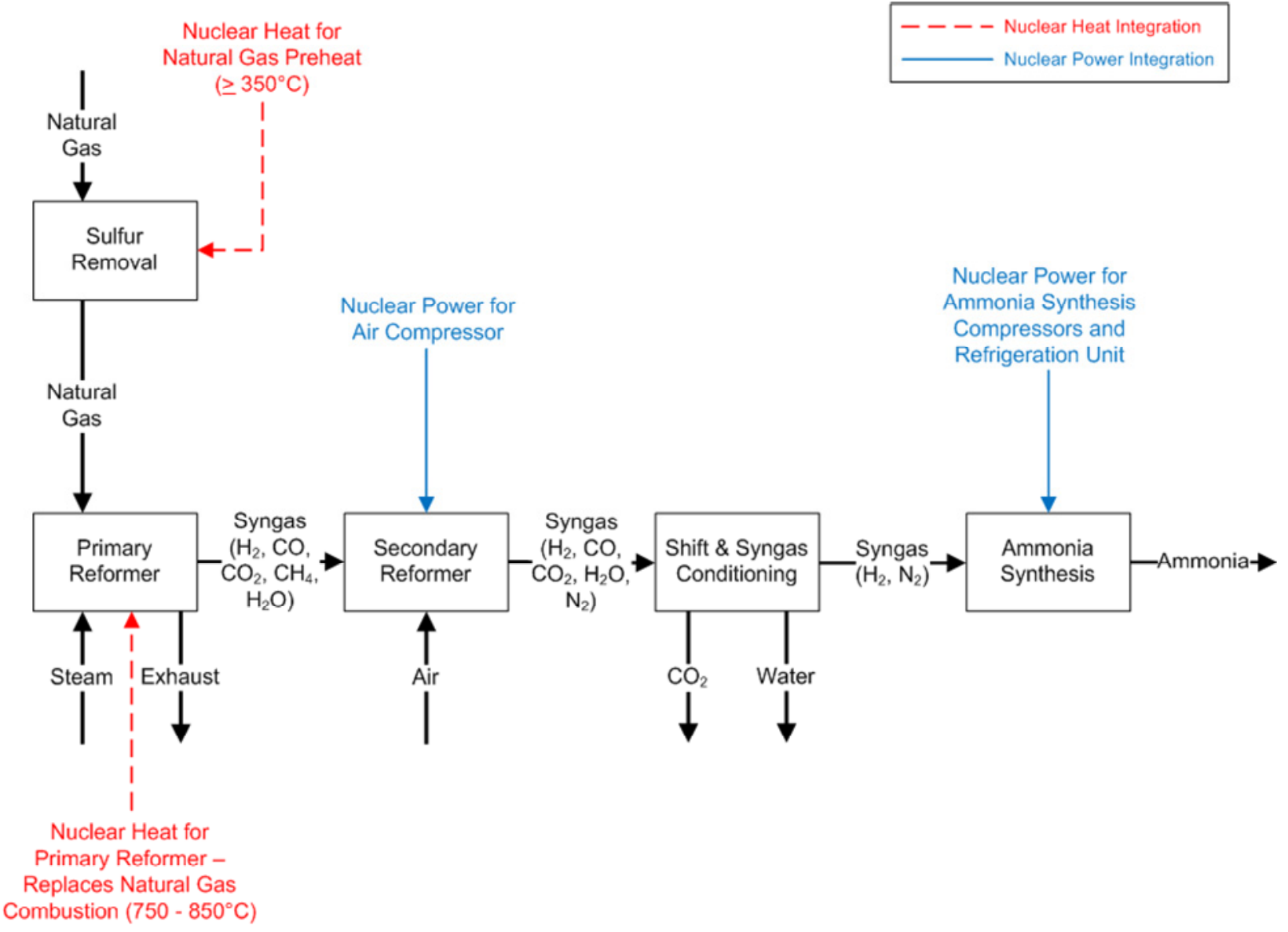

Figure 26. Use of the HTGR instead of natural gas firing in the primary reforming stages.

In the second case, the HTGR plant produces high purity hydrogen and oxygen using the HTSE process. The high purity hydrogen is delivered directly to the ammonia synthesis reactor along with nitrogen produced from a cryogenic air separation unit powered by HTGR generated electricity. A simplified flow sheet for this process is shown in Figure 27. This latter use of the HTGR plant eliminates all of the reforming and purification equipment required to supply the hydrogen from decomposition of natural gas in a conventional process. This reduces the capital investment and operating costs of the ammonia plant, making the use of hydrogen and nitrogen directly for ammonia synthesis potentially more economically attractive. 


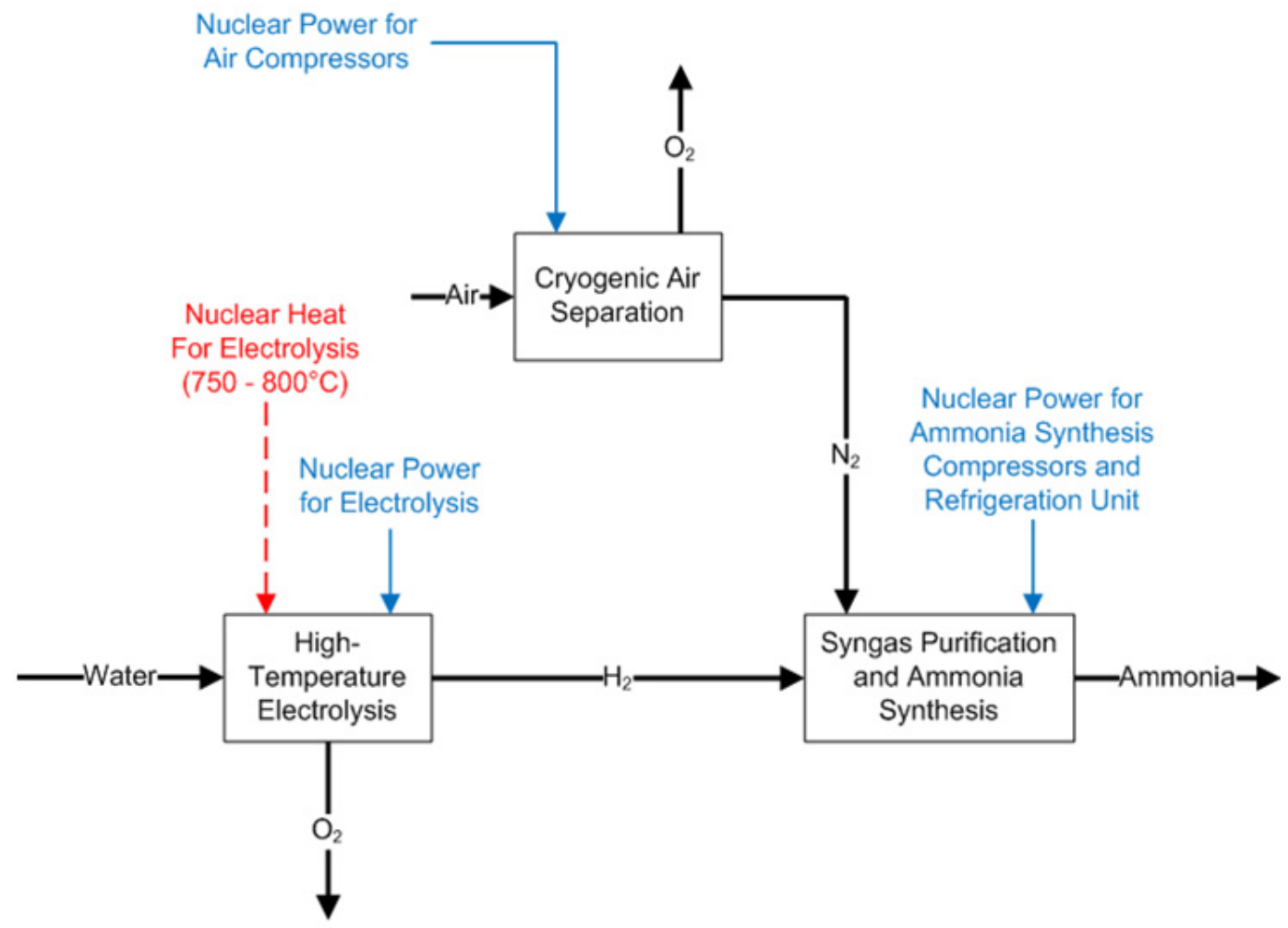

$-\ldots--$ Nuclear Heat Integration
- Nuclear Power Integration

Figure 27. Use of the HTGR for supply of hydrogen directly to the ammonia syntheses reactor.

Both of these uses of the HTGR energy source result in significant reductions in $\mathrm{CO}_{2}$ emissions compared with the conventional process. Figure 28 summarizes the outputs for the two HTGR cases with the conventional plant. Depending on the case, the emissions that would be emitted from a conventional process are reduced by $22 \%$ (Case 1, 1,000 tons of $\mathrm{CO}_{2}$ emissions per day) to $98 \%$ (Case 2, 3850 tons of $\mathrm{CO}_{2}$ emissions per day). 

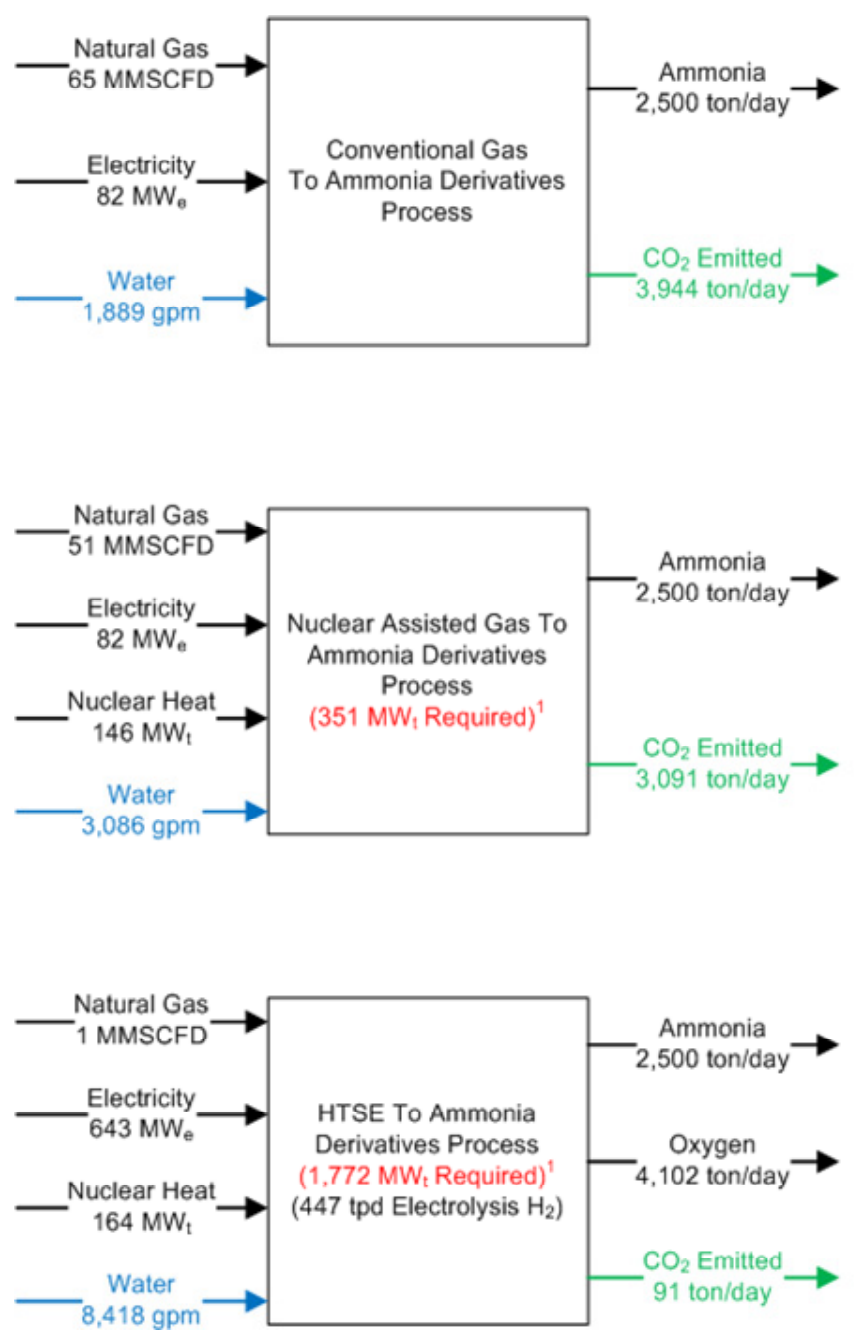

${ }^{1}$ Assumes HTGR power generation efficiency of $40 \%$

Figure 28. Summary of results for use of the HTGR for ammonia production.

Figure 29 summarizes the results of scoping economic comparisons of the two HTGR integrated plants with a conventional ammonia production plant as a function of the costs for $\mathrm{CO}_{2}$ emissions in $\$ /$ ton emitted. The comparison shows the ammonia prices in $\$ /$ ton that would need to be charged to meet the criteria summarized on this figure (e.g., a 15\% internal rate of return on invested equity with a $80 \%$ debtto-equity ratio). The calculations assume a base price of $\$ 6.5 / \mathrm{MMBtu}$ for the natural gas supply.

The use of the HTGR process heat plant as a substitute for some of the burning of natural gas in a conventional plant has pricing that varies in a manner similar to that of the conventional plant (see Figure 29). Because this case only offsets a fraction of the natural gas combustion, the required pricing increases with the costs of carbon emissions at a rate slightly lower than that for the conventional process. The ammonia pricing for the HTGR process heat plant is comparable to that of the conventional plant at costs of $\$ 50 /$ ton of $\mathrm{CO}_{2}$ emissions.

Figure 29 also shows the results for the option wherein the HTGR hydrogen plant supplies pure hydrogen that is combined directly with nitrogen generated from an ASU in the ammonia synthesis reactor. Ammonia pricing for the economic conditions shown in the HTGR hydrogen plant is projected to be comparable to that of the conventional plant at $\mathrm{CO}_{2}$ emission costs of $\sim \$ 160 /$ ton. The economics for this case are based on designs and performance of the HTGR and HTSE plants developed in the NGNP Project FY 2007 preconceptual design task. The Project is continuing to support development and optimization of the HTSE process and the full capabilities of the HTGR technology. As these technologies develop the technical and economic viability of the HTGR technology will be revisited and discussed with potential end users. 


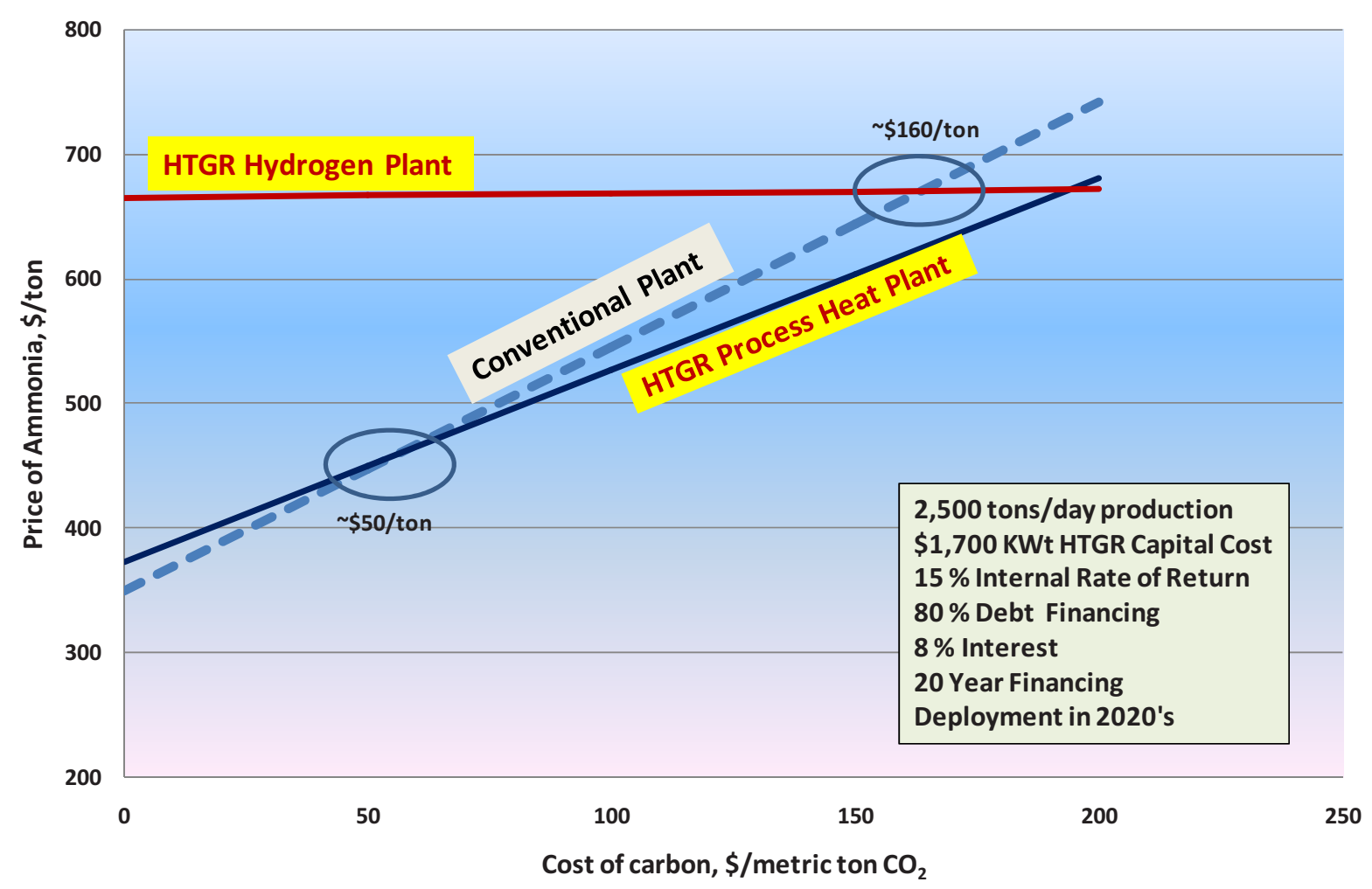

Figure 29. Comparison of conventional and HTGR integrated plant urea pricing vs. costs for $\mathrm{CO}_{2}$ emissions. (Developed in Excel file, "Ammonia Economics - Separating the Process from the HTGR 8-02-10").

\subsection{Hydrogen Generation and Effect of Uncertainties on Economic Evaluations}

The economics of integrating the HTGR and the HTSE hydrogen plant with the coal-to-MTG and ammonia production processes are very sensitive to the price of hydrogen produced by the HTGR/HTSE plant. The hydrogen price is similarly affected by the assumptions used in the calculation. The economic calculations presented in Figures 24, 25, and 29 reflect a hydrogen price in the $\$ 3.2 / \mathrm{Kg}$ range. This is judged to be representative of current knowledge of the costs and performance of the HTGR and HTSE plants. However, because HTGR design development is still in the preconceptual phase, there is a large uncertainty in the factors applied to calculate this price. To establish the impact of this uncertainty on the price of hydrogen, sensitivity analyses were performed to determine the effect of variations in the principal assumptions applied to calculate this price. The results of these sensitivity analyses are summarized in the tornado chart of Figure 30, which shows the effect of variations in the debt-to-equity ratio, required internal rate of return, plant overnight cost, financing term, operating costs, and interest rates such as interest during construction and financing interest. The variation in each parameter investigated in the sensitivity analyses and the baseline value for each parameter are shown on this chart.

As expected, the first three parameters have the most effect on the results. The total variation shown on the chart ranges from a low of $\$ 2.36 / \mathrm{Kg}$ to a high of $\$ 4.25 / \mathrm{Kg}$, driven by the variation in debt-to-equity ratio investigated ( 90 to $0 \%$ ). Note that it is not appropriate to sum up all of the extremes shown on a tornado chart to estimate the full range over which the price of hydrogen could vary. These variations will actually combine in a more random way. To provide an assessment of the full range of expected variation in hydrogen pricing for the ranges assumed for the parameters, a Monte-Carlo analysis was performed using triangular distributions of these factors over the ranges shown in Figure 30.

Figure 31 shows the results of this analysis as a probability distribution for the hydrogen price. The mean of the analysis $(\$ 3.18 / \mathrm{Kg})$ conforms well with the baseline price of Figure 29 . The wide swing in the 1 -sigma span $(\$ 2.69 / \mathrm{Kg}$ to $\$ 3.68 / \mathrm{Kg})$ reflects the large uncertainty in the pricing. 


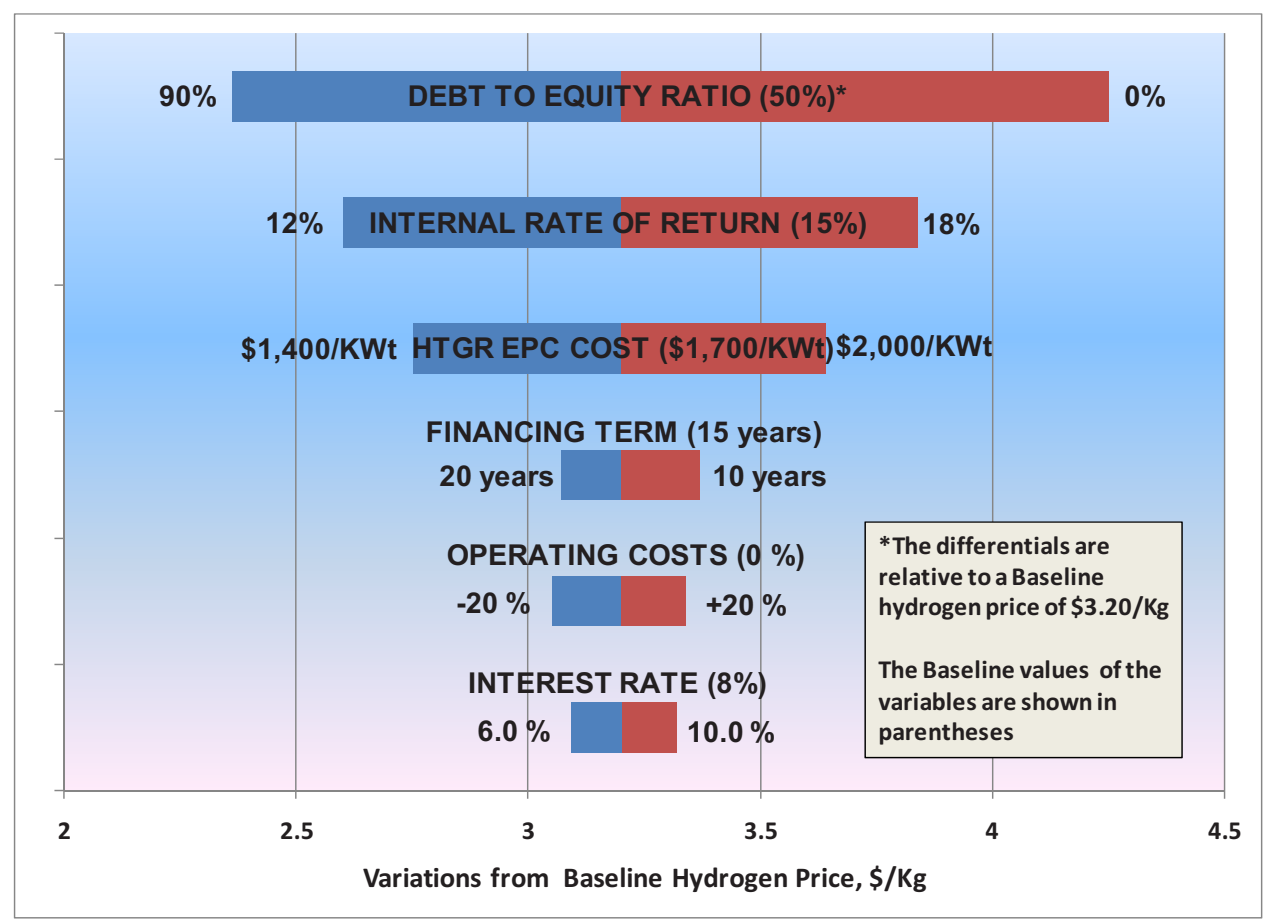

Figure 30. Effect of variations in financial parameters on hydrogen pricing. (Developed in Excel file, "HTGR $\mathrm{H}_{2}$ Tornado Chart Development 7-22-10").

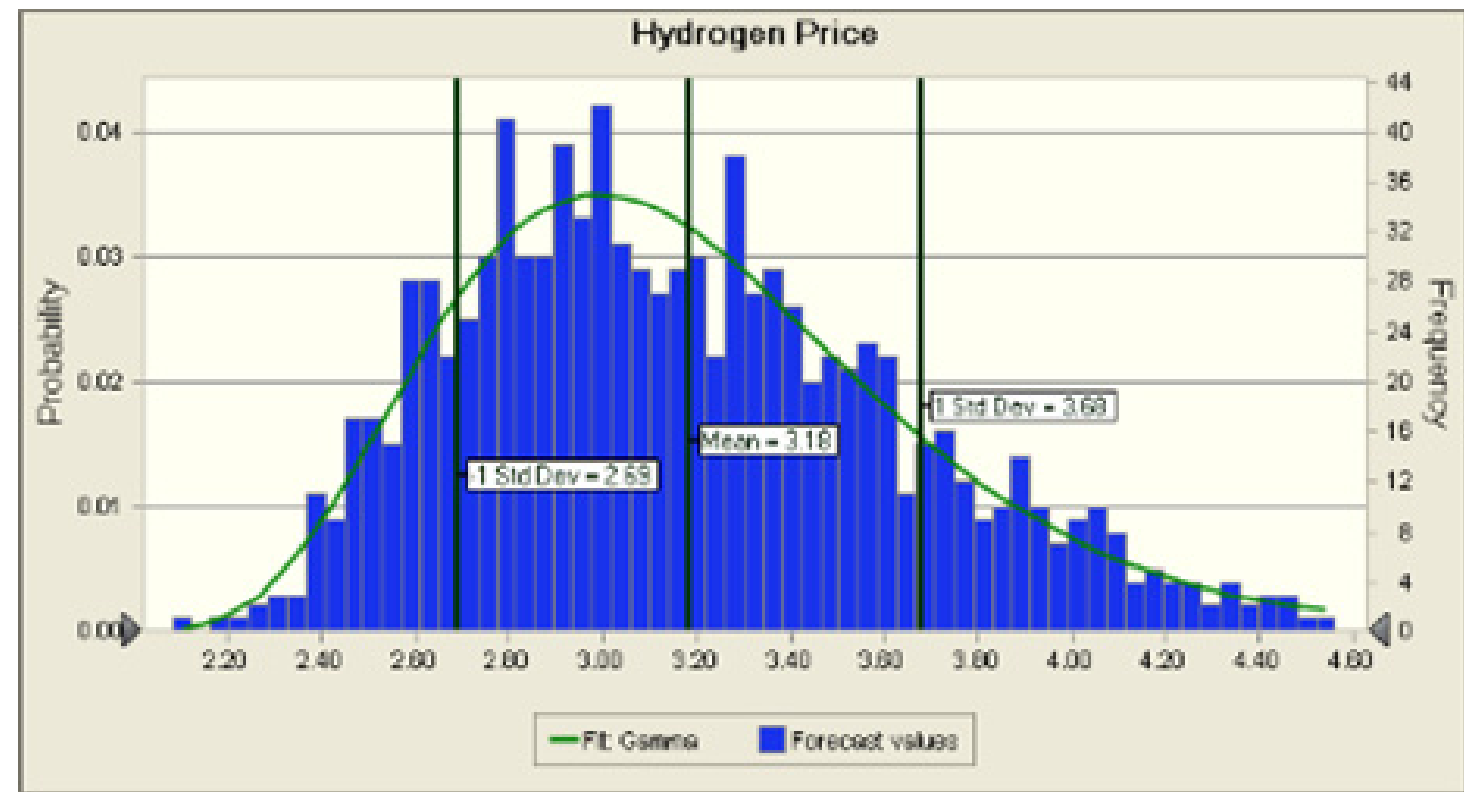

Figure 31. Probability distribution of hydrogen pricing. (Developed in Excel file, "HTGR H2 Cost Monte Carlo Analysis using Crystal Ball 6-9-10").

As cited previously, the majority of non-refinery hydrogen is produced using natural gas as the feedstock and energy source in the SMR process. The price of hydrogen using the SMR process is therefore a strong function of the price of natural gas. Figure 32 presents this variation assuming a new SMR process installation, the financial factors used in the economic evaluations presented above, and typical operating costs, excluding the cost of natural gas. The evaluation was completed for a plant generating $\sim 35,000 \mathrm{lb} /$ day of hydrogen with a natural gas usage of $121,000 \mathrm{lb} /$ hour. ${ }^{18}$ The Hydrogen pricing for the SMR process is shown as a function of the price of natural gas (\$/MMBtu) and the cost of carbon emissions $\left(\$ / \mathrm{MT}\right.$ of $\left.\mathrm{CO}_{2}\right)$. 


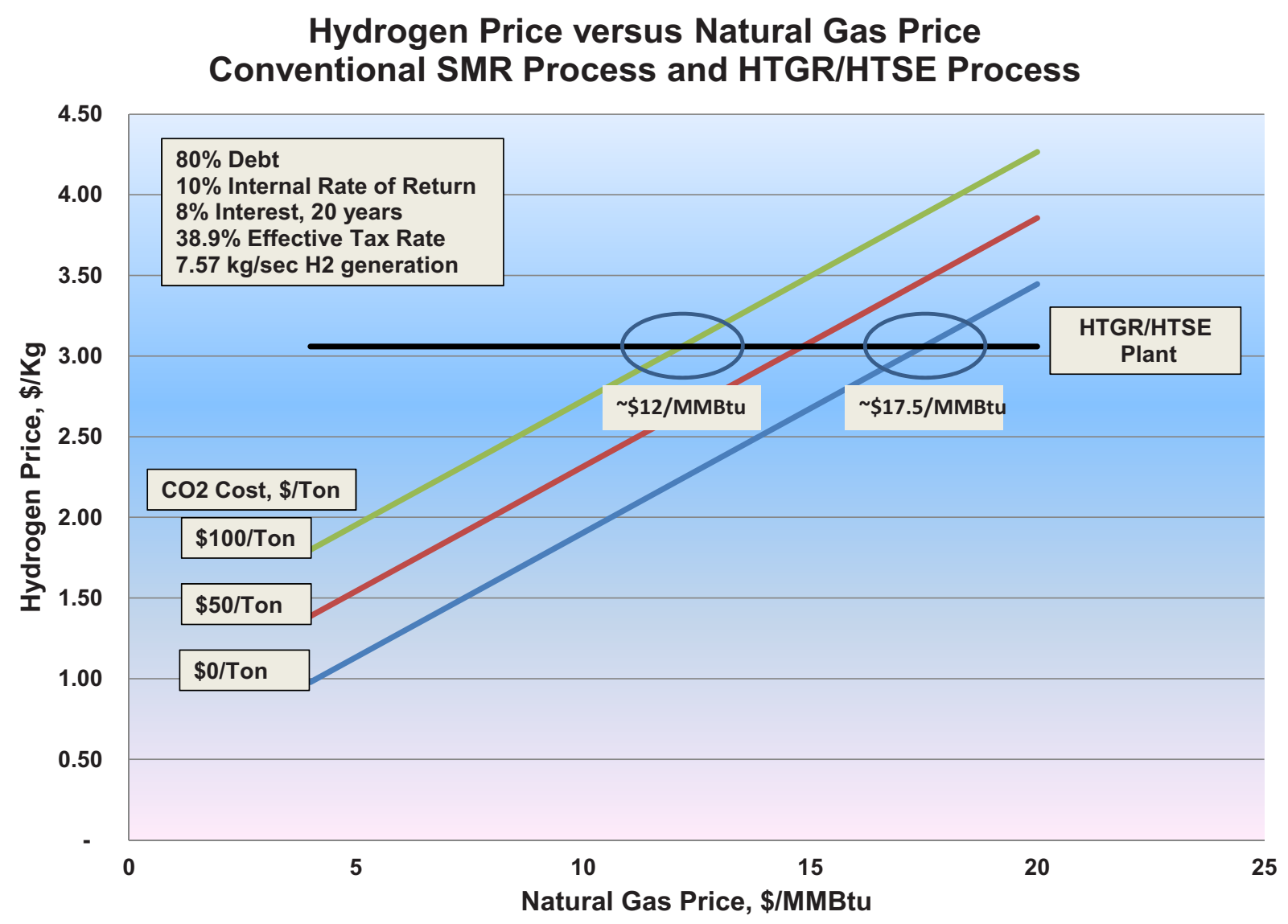

Figure 32. Comparison of hydrogen pricing using SMR and HTGR/HTSE technologies. (Developed in Excel file, "Backup calcs on Industrial Sector \& Emissions and CTL Plant 6-7-10 \& Baseline Hydrogen Plant - 5-600 MWt, $7.57 \mathrm{Kg} / \mathrm{sec}$ 8-16-11").

The price of hydrogen for the HTGR/HTSE process is for a HTGR plant cost of $\sim \$ 1,700 / \mathrm{kWt}$ and nominal financial factors assumed by the Project for a mature plant installation, (80\% debt, 10\% IRR). As shown in Figure 32, the HTGR/HTSE process intersects with the SMR pricing at natural gas prices from $\$ 12 / \mathrm{MMBtu}$ to $\$ 17.5 / \mathrm{MMBtu}$ depending on the cost of carbon emissions.

As cited previously the NGNP Project evaluated the application of HTGR energy as a substitute for burning of natural gas in the Steam Methane Reforming process. ${ }^{9,19}$ Although the reductions in $\mathrm{CO}_{2}$ emissions and natural gas consumption are not as favorable for this application of the HTGR technology for hydrogen production the economics are better. Figure 33 compares the price of hydrogen generated using the conventional with the HTGR-integrated SMR processes as a function of the price of natural gas. As shown the HTGR/SMR process is more economic for natural gas prices above \$6.5/MMBtu.

At the time of this writing the supply to demand ratio of natural gas is sufficient to establish a price at the lower end of the range of prices experienced over the preceding decade. At this price the economics of the HTGR in comparison with a comparable natural gas fired plant are not favorable. However, the supply to demand ratio is trending to support a higher price because of uses of natural gas for base-loaded electricity production and initiation of significant export. These factors may drive the price of natural gas to the point where the HTGR economics are more favorable. It should also be noted that the HTGR technology is slated to become available for commercial application in the mid-2020s and has a design lifetime of 60 years. As shown in Figure 16, over the past 40 years the price of natural gas has shown an average escalation of $2 \%$ above inflation. It is not likely that the price of natural gas will remain near its current historical low or buck this historical trend in price escalation into the time frame in which the HTGR technology is available for deployment. 


\section{Price of Hydrogen as a Function of Natural Gas Price Conventional and HTGR Integrated SMR \& HTSE}

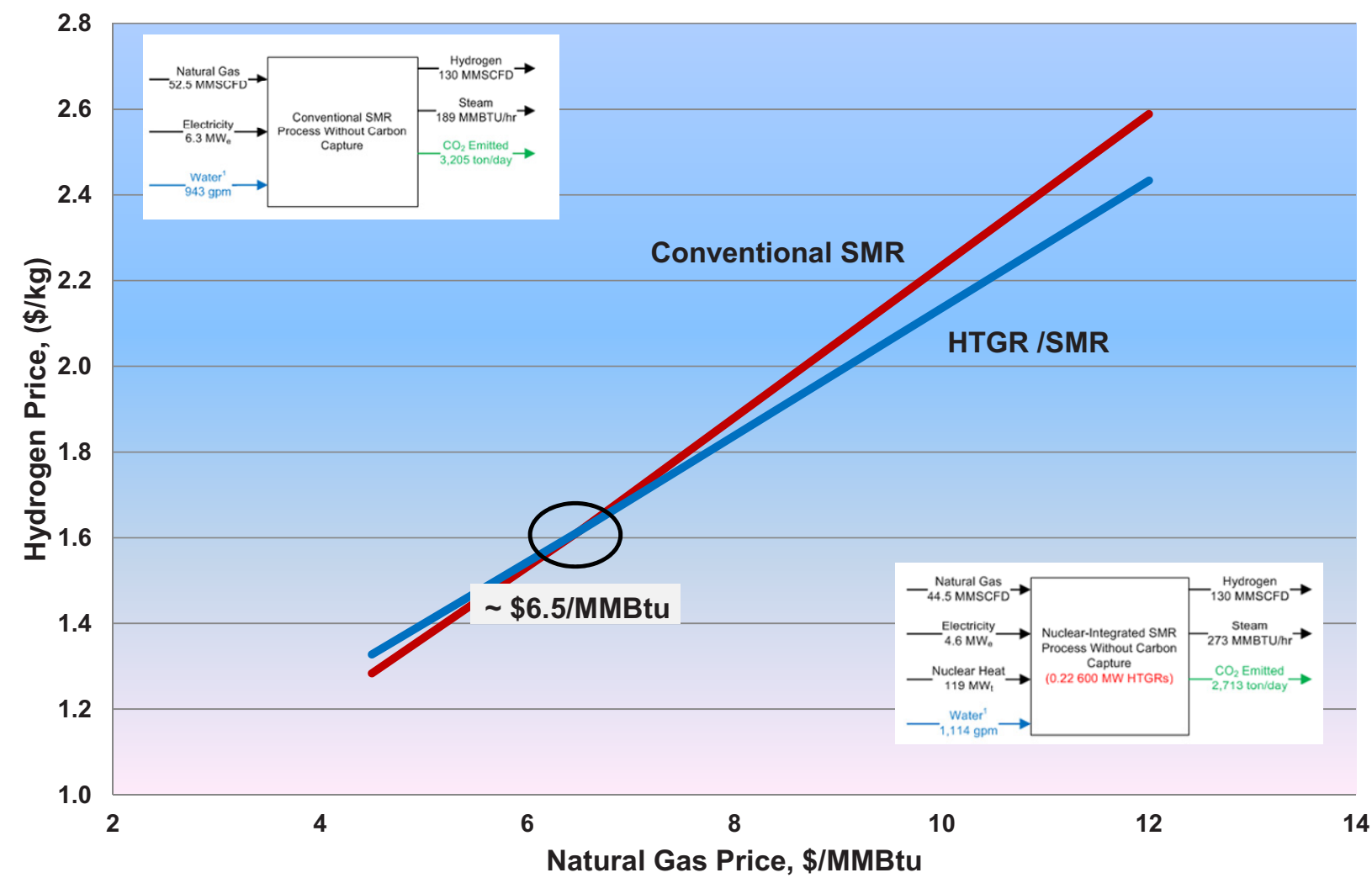

Figure 33, Price of Hydrogen as a Function of Natural Gas Prices for Conventional and HTGR-Integrated Steam Methane Reforming Processes (Developed from Excel file, " $\mathrm{H}_{2}$ from SMR \& SMR w_HTGR Plotting for Presentations" \& Reference 19).

\subsection{Conclusion on Application Economics}

To develop confidence in the technical and economic viability of the HTGR technology, the design of the plants needs to be developed to provide better estimates of performance and costs to construct and operate. The economic factors for financing and pricing of energy over the long operating lifetime of HTGR plants need to be refined through further discussions with major financial institutions with an energy portfolio, current nuclear plant owners, and major industrial plants that can benefit from use of energy supplied from the HTGR. Additionally, the long term financial benefit of this technology to the end user has not been quantified in the evaluations performed to-date. The benefits of a long term secure and stable price of energy have been summarized qualitatively in this report. These factors may combine to permit the end user to accept a higher than current market cost that will be stable over the long term. This factor has not been accounted for in economic evaluations of the technology presented in this report. How to account for this fact is being pursued with the end users and other stake holders involved in the development of the HTGR technology.

The NGNP Project is developing updated and more refined economic models for evaluating the viability of the business models for both the HTGR plant and the industrial plant for the processes evaluated to-date and for those for which evaluations are to be completed. As the HTGR plant designs evolve, better estimates of the capital and operating costs for these plants will be developed that support higher confidence levels in the results of the economic models. The scoping economic analyses performed to-date do show that the HTGR technology has the potential to be competitive with many conventional industrial processes while offering significant benefit in stabilizing energy prices, providing secure energy sources, and reducing $\mathrm{CO}_{2}$ emissions. The HTGR process may be favored in specific 
applications if there are governmental regulations that make it more attractive, lower costs and better financing were available, and other factors, such as stability in energy supply and pricing, were major factors.

As the technology develops and as U.S. energy policies and/or direction become better defined, the technical and long term economic viability of the HTGR applications will continue to be reevaluated and reviewed. 


\section{REFERENCES}

1. Demick, L. E., Transforming the U.S. Energy Infrastructure, INL/EXT-09-17436, Idaho National Laboratory, July 2010.

2. Public Law 109-58, Energy Policy Act of 2005, August 8, 2005.

3. MPR-3181, "Survey of HTGR Process Energy Applications," Rev 0, May 2008.

4. AEO, “Annual Energy Outlook 2009 with Projections to 2030,” DOE/EIA-0383(2009), March 2009; and, "Assumptions to the Annual Energy Outlook 2009 with Projections to 2030," DOE/EIA0554(2009), March 2009 and AEO 2011 Early Release, December 2010.

5. General Atomics, Conceptual Design Report - Steam Cycle Modular Helium Reactor, (SC-MHR) Demonstration Plant, NGNP-R00016, December 2010.

6. U.S. Energy Information Administration, NPRA United States Refining and Storage Capacity Report, January 21, 2010, Published August 2010.

7. DOE, The Impact of Increased Use of Hydrogen on Petroleum Consumption and Carbon Dioxide Emissions, SR-OIAF-CNEAF/2008-04, August 2008.

8. G. Bromaghim, K. Gibeault, J. Serfass, P. Serfass, E. Wagner, Hydrogen and Fuel Cells: The U.S. Market Report, A Report by the National Hydrogen Association on 2008 Data, March 22, 2010.

9. TEV-953, "Nuclear-Integrated Hydrogen Production via Steam Methane Reforming (SMR) Process Analysis," Idaho National Laboratory, August 2010.

10. TEV-693, "Nuclear-Integrated Hydrogen Production Analysis," Idaho National Laboratory, May 15, 2010.

11. TEV-704," Nuclear-Integrated Hydrogen Production via Steam Methane Reforming (SMR) Process Analysis," Idaho National Laboratory, May 2010.

12. Nelson, L., A. Gribik, V. Maio, M. McKellar, M. Patterson, and R. Wood, Integration of High Temperature Gas-Cooled Reactors into Industrial Process Applications, INL/EXT-09-16942, Revision 2, Idaho National Laboratory, May 2010.

13. Updated Capital Cost Estimates for Electricity Generation Plants, November 2010 \& Levelized Cost of New Generation Resources in the Annual Energy Outlook 2011, based on Energy Information Administration, Annual Energy Outlook 2011, December 2010, DOE/EIA-0383(2010).

14. ADMIN, Barack Obama and Joe Biden Policy Paper, "Promoting a Healthy Environment," http://www.barackobama.com/pdf/issues/EnvironmentFactSheet.pdf, Website visited 8/16/2010.

15. Sandia National Laboratory, "FY09 Projected Hydrogen Cost Estimates for Nuclear Hydrogen Initiative Baseline Processes," S and 2009-6630P, December 2009.

16. Nelson, L., A. Gandrik, M. McKellar, E. Robertson, M. Patterson, and R. Wood, Integration of High Temperature Gas-Cooled Reactors into Selected Industrial Process Applications, INL/EXT-1123008, Idaho National Laboratory, August 2011.

17. TEV-1196, "Assessment of High Temperature Gas-Cooled Reactor (HTGR) Capital and Operating Costs,” Idaho National Laboratory, April 2011.

18. DOE, 2008, "Current (2005) Hydrogen from Natural Gas without $\mathrm{CO}_{2}$ Capture and Sequestration," Excel File, U.S. DOE/NETL, May 2008.

19. TEV-954, "Nuclear-Integrated Hydrogen Production via Steam Methane Reforming (SMR) Economic Analysis," Idaho National Laboratory, August, 2010. 